\title{
Late Holocene land vertebrate fauna from Cueva de los Nesofontes, Western Cuba: Stratigraphy, chronology, diversity, and paleoecology
}

\author{
Johanset Orihuela, Leonel Pérez Orozco, Jorge L. Álvarez Licourt, \\ Ricardo A. Viera Muñoz, and Candido Santana Barani
}

\begin{abstract}
Here we report a late Holocene fossil-rich cave deposit from Cueva de los Nesofontes, Mayabeque Province, Cuba. The deposit's formation and its fauna were studied through a multidisciplinary approach that included stable isotope analyses, radiocarbon chronology, and stratigraphy. Thousands of microvertebrate skeletal remains were recovered, representing a diverse land vertebrate fauna that included threatened and extinct species. The deposit is characterized by profuse Nesophontes remains due to raptor predation. Previously unreported last appearance dates (LADs) are provided for the extinct 'island-shrew' Nesophontes major, the bats Artibeus anthonyi, and Phyllops vetus. Radiocarbon ( ${ }^{14} \mathrm{C}$ AMS) age estimates between $~ 1960$ rcyr $\mathrm{BP}$ and the present were acquired for the assemblage. The presence of locally extinct species, including the endemic parakeet Psittacara eups, the flicker Colaptes cf. fernandinae, the bat Antrozous koopmani, and the eulipotyphlan Solenodon cubanus, suggests that these species had broader distributions in the near past. Isotope analyses and faunal composition indicate the previous presence of diverse habitats, including palm grove savannas and mixed woodlands near the cave. Isotopes also provide insight into the habitat and coexistence of the extinct bat Artibeus anthonyi and extant A. jamaicensis, the diet of Nesophontes major, and local paleoenvironmental conditions. Oxygen isotopes reveal an excursion suggestive of drier/colder local conditions between 660 and $770 \mathrm{AD}$. Our research further expands the understanding of Cuban Quaternary extinction episodes and provides data on the distribution and paleoecology of extinct taxa. It supports the conclusion that many Cuban extinct species survived well into the pre-Columbian late Holocene and retained wide distribution ranges until European colonization.
\end{abstract}

Orihuela, Johanset, Pérez Orozco, Leonel, Álvarez Licourt, Jorge L., Viera Muñoz, Ricardo A., and Santana Barani, Candido. 2020. Late Holocene land vertebrate fauna from Cueva de los Nesofontes, Western Cuba: Stratigraphy, chronology, diversity, and paleoecology. Palaeontologia Electronica, 23(3):a57. https://doi.org/10.26879/995 palaeo-electronica.org/content/2020/3232-late-holocene-fauna-from-cuba 
Johanset Orihuela. Department of Earth and Environment (Geosciences), Florida International University, Miami, Florida 33199, USA. Paleonycteris@gmail.com

Leonel Pérez Orozco. City of Matanzas Conservator, Matanzas 40100, Cuba. histmatanzas@ohc.cu

Jorge L. Álvarez Licourt. Miami, Florida 33175, USA. espelunca3@gmail.com

Ricardo A. Viera Muñoz, Miami, Florida 33185, USA. sancarlossanseverino@gmail.com

Candido Santana Barani. Matanzas 40100, Cuba. histmatanzas@ohc.cu

Keywords: Antillean; Cave; Microvertebrates; late Holocene

Submission: 29 April 2019. Acceptance: 15 November 2020.

\section{INTRODUCTION}

Cave deposits have been, and continue to be, the richest source of Quaternary extinct land vertebrate fossils in the Greater Antilles. Caves harbor different kinds of bone deposits, including accumulations due to natural death of cave inhabitants, visiting species, raptor-derived pellets (e.g., mostly from owls), and dietary middens created by humans. In Cuba, these forms of bone accumulation have provided a rich vertebrate record of the island's late Quaternary faunas, an essential source for understanding Antillean biogeography and extinctions (Morgan and Woods, 1986; Morgan, 1994; MacPhee et al., 1999).

Faunal deposits accumulated in Cuban caves were initially discovered during the mid-late nineteenth century and the first decades of the twentieth century. These early efforts included discoveries by José Figueroa, Fernández de Castro, and Carlos de la Torre at several localities throughout the island between 1860 and 1911 (de la Torre, 1910; Nuñez Jiménez, 1998; Goldberg et al., 2017). Later explorations were conducted by Barnum Brown (1913), Thomas Barbour, and other personnel from the Museum of Comparative Zoology (Cambridge), Carnegie Museum (Philadelphia), and the American Museum (New York City). Gerrit S. Miller (1916) and Harold E. Anthony described faunas from fossil and subfossil material found in cave deposits in eastern Cuba (Anthony, 1917, 1919), as did Peterson (1917) and Glover M. Allen in western Cuba (Allen, 1917, 1918), providing thereby the first micromammal fauna accounts from the island.

Until recently, Cuban cave fossil deposits had been rather arbitrarily considered to be of late Pleistocene age (e.g., Brown, 1913; Allen, 1918; Anthony, 1919; Koopman and Williams, 1951; Arredondo, 1970; Acevedo et al., 1975; Woloszyn and Silva Taboada, 1977; Acevedo and Arredondo, 1982; Rivero and Arredondo, 1991; Salgado et al., 1992; Balseiro, 2011). However, the few existing radiocarbon dates from non-cultural vertebrate assemblages reported from Cuba now indicate that such faunal accumulations are often much younger in age than previously expected (MacPhee et al., 1999, 2007; Jull et al., 2004; Jiménez et al., 2005; Steadman et al., 2005; Orihuela, 2010, 2019; Orihuela and Tejedor, 2012; Orihuela et al., 2020a). So far, only three cave deposits have yielded true Pleistocene faunas: Cueva El Abrón, in Pinar del Río province (Suárez and Díaz-Franco, 2003), the tar deposits of San Felipe (Jull et al., 2004) and the thermal bath deposits of Ciego Montero (Kulp et al., 1952). Even though the Cuban record is one of the richest and most diverse of the Greater Antilles, it remains the least understood in terms of chronology due to the lack of reliable age estimates and discrete faunal analyses.

Such lack of chronologic resolution, which can be achieved through detailed sedimentological, stratigraphically, and direct "last appearance dates" (LADs), limit our understanding of the timing of loss for most of its extinct or extirpated land vertebrate fauna. So far, of the 21 extinct land mammals, including bats, currently recognized for Cuba (Silva Taboada et al., 2007), only three, plus two birds, have direct LADs (MacPhee et al., 1999; Jull et al., 2004; Steadman et al., 2005; Orihuela, 2019; Orihuela et al., 2020a). Generating additional direct and indirect LADs are crucial to constrain extinction chronologies against known past humancaused environmental changes in Cuba (Orihuela et al., 2020a, 2020b).

Here we provide a detailed, multi-proxy analysis of an exceptionally rich cave deposit from northwestern Cuba. Our interpretation of the deposit's radiocarbon chronology, stratigraphy, and taphonomy, in addition to analyses of stable isotopes and faunal composition, contributes to the understanding of Cuban faunal diversity and biogeography by providing insight into the distribution, coexistence, diet, habitat, and timing of extinction of a wide array of Quaternary taxa. The diversity and age of 
the deposit, plus new direct ${ }^{14} \mathrm{C}$ LADs for Cuban extinct or endangered endemics, provide a unique opportunity to study a faunal assemblage that spans the critical interval between Amerindian (indigenous) arrival and European colonization, thus contributing to the overall understanding of Antillean land vertebrate extinction and biogeography.

\section{MATERIALS AND METHODS}

\section{Geological and Environmental Settings}

Cueva de los Nesofontes is one of several caves located on Loma El Palenque or Palenque Hill: lat. $23.016^{\circ} \mathrm{N}$ and long. $-81.722^{\circ} \mathrm{W}$. This hill, with a $327 \mathrm{~m}$ altitude, is one of the most prominent elevations of the Alturas Habana-Matanzas orographic region, in northwestern Cuba (Acevedo, 1992). Its current geopolitical position lies within the easternmost limit of Mayabeque province but was formerly included within the Province of Matanzas (Figure 1).

Palenque is a karstic formation composed of massive (i.e., non-stratified) biodetrictic limestones of the Jaruco Formation (Fm). Previously, this hill was erroneously attributed to the Eocene (Nuñez Jiménez et al., 1984; lapsus in Orihuela, 2010). However, its microfauna, generally comprised of sponges, corals, mollusks, index benthic foraminifera, and echinoderms, suggest that the Jaruco Fm formed in an oxygenated, warm, tropical, neritic sublittoral-platform environment during
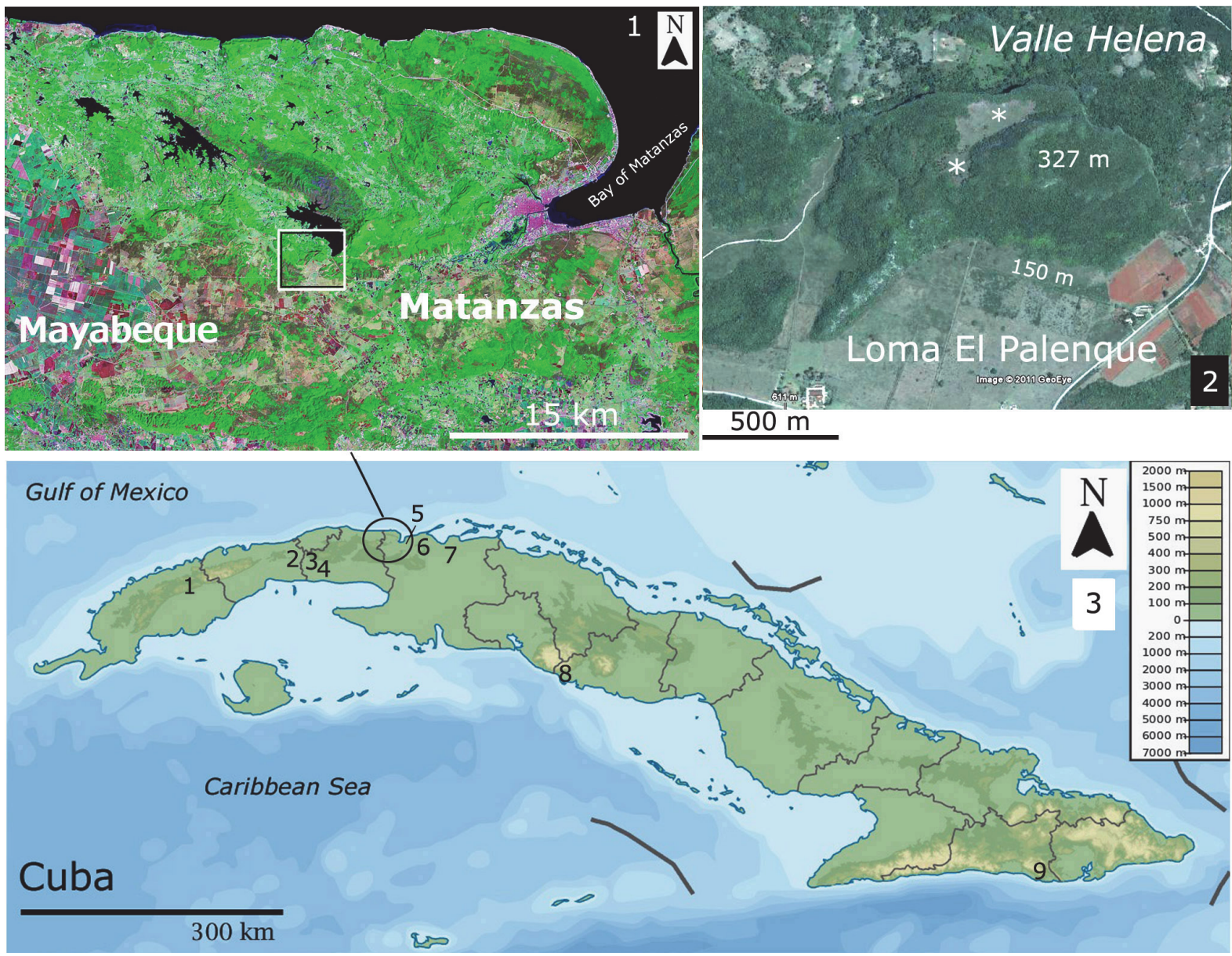

FIGURE 1. Location of Loma del Palenque and Cueva de los Nesofontes in northwestern Cuba. 1, Landsat image of the Mayabeque-Matanzas region, indicating the area of the Loma del Palenque (Palenque Hill). 2, Satellite image of Palenque Hill. The asterisks $\left(^{*}\right)$ indicate a flat scarp at $\sim 260 \mathrm{~m}$ where red-clay soils have formed, are the main source of the allochthonous sediment inside the cave. 3, Map of the Cuban archipelago, indicating the localities mentioned in the text: 1, Cueva El Abrón, GEDA, and Mono Fósil, Pinar del Río; 2, Cueva de Paredones, Artemisa; 3, Cueva del Túnel, Mayabeque; 4, Cuevas Blancas, Mayabeque; 5, Cueva del Gato Jíbaro, Matanzas; 6, Cueva Calero, Matanzas; 7, Breas de San Felipe, and Cuevas de Hato Nuevo, Matanzas; 8, Cueva de los Masones and Jagüey, Trinidad, Las Villas; and 9, Cueva del Indio, Daiquirí, Santiago de Cuba. 
the late Oligocene and the early Miocene, $\sim 28-20$ Ma (Iturralde-Vinent, 1969a, Iturralde-Vinent, 1969b, 1977, 1988).

Five thin sections prepared from several hand samples collected around the hill support the interpretations in the latest Cuban Geologic Lexicon (2014, p. 188). The microfauna identified from those samples included large Lepidocyclina spp. and Heterostegina antillea, Miogypsina cf. antillea, and the planktonic Globigerina spp. Heterostegina antillea is an index taxon of the upper Oligocene and lower Miocene (BouDagher-Fadel, 2008). The presence of Miogypsina at $265 \mathrm{~m}$ above the upper scarp (surface of Palenque as defined by Ducloz, 1963) supports an extension for the possible formation up to the middle Miocene ( $\mathrm{JO}$, unpublished data).

As in the case of the rest of the HabanaMatanzas range, neotectonic uplift and differential erosion during the Pleistocene (<2.6 Ma: IturraldeVinent, 1988) affected the exposure of the hillside. Two of its scarp levels (the highest is indicated by asterisks in Figure 1) have been interpreted as an early-middle Pleistocene marine terrace (IturraldeVinent, 1969a, 1969b, 1977), known as the "Palenque Surface" (Ducloz, 1963). Thus, we consider the age of the caves found within the hill to be at least late Pliocene or younger. Decomposition of exposed limestone formed the red clay ferralitic soils and loams occurring in upper escarpments (>250 m asl). These are known as the Matanzas red soil series (Formell and Buguelskiy, 1974), now considered as the late Quaternary Villaroja Fm (Cuban Geological Lexicon, 2003, 2014). In terms of composition, these are the same that occur at the openings and inside of caves and fractures at Palenque, and likely date to middle Pleistocene or later.

The climate in the region today is tropical, with warm temperatures between 32 and $23 \mathrm{C}^{\circ}$ during the wet season (May-October), with average rainfall between 1300 and $1500 \mathrm{~mm}$ (Cuban National Atlas, 1989). During the cold-dry season (November-April) temperatures range between 18 and 26 $C^{\circ}$ (Cuban National Atlas, 1989). We registered temperatures of $6 \mathrm{C}^{\circ}$ inside the main gallery during the night of December 24, 2003.

Premodern vegetation was comprised of semideciduous woodlands over karst terrain and mogote forests at a higher elevation (typical mesophyll, Del Risco Rodríguez, 1989). Today the hill is covered in secondary, but well preserved, semideciduous forest surrounded by savannas and agricultural land with lakes and rivers (Figure 1). The present vegetation on the hill includes the gumbolimbo (Bursera simaruba), oaks, and mahogany (Quercus sp. and Swietenia sp.), the guao (Comocladia dodonea), chichicate (Urtica doica), Thrinax radiata and Coccothrinax crinita palms, and Fabaceae in the upper levels. The royal palm (Roystonea regia) and other agricultural plants spread through. Coffee (Coffea arabica) grows in the upper escarpment of the hill, and their plant remains have been observed in Artibeus jamaicensis roosts therein. During the colonial period, the region around the hill featured agricultural use for sugar cane fields and coffee plantations.

\section{Site-deposit Description and History of Research}

The caves of Palenque were discovered during the late 1960s, but not fully explored or excavated until 1983-1985 by the Norbert Carteret group of the Cuban Speleological Society (Vento Canosa, 1990). The deposit we studied and interpret here is located inside the main gallery at Cueva de los Nesofontes, a large phreatic-vadose cave near the uppermost escarpment of Palenque (Figures 1-2). The deposit is a large deposition cone situated $\sim 9 \mathrm{~m}$ above the main gallery level (datum $\sim 240 \mathrm{~m}$ ), dipping at an angle of $22-28^{\circ}$, under a 15-meter-wide dissolution sinkhole. This sinkhole or main doline opens to other larger sinkholes with openings to the side of the hill (Figure 2 ). These upper caves and sinkholes are the source of the primary deposits and modern raptor roosts in which faunal remains occur or are derived from (Figure 2.2-3).

The deposit contains over $400 \mathrm{~m}^{3}$ of exceedingly rich fossiliferous sediment, which has been transported through the main sinkhole onto the cave's deposition cone (Figure 2). The sediment is rill-eroded, composed of red-ferralitic soil with redoximorphic features. It is generally colored in dusky red hues and is rich in terrestrial mollusks and Nesophontes remains. This abundance suggested the name of the cave as the Cave of the Island Shrew or Cueva de los Nesofontes. This cave is alternatively known as Cueva de la Caja or the Cave of the Box (e.g., Viera, 2004; Orihuela, 2019; Orihuela et al., 2020a, 2020b).

The room where the main doline and deposit are located is littered with roof-fall boulders, smaller rocks, fallen tree branches, and leaves. The lowest level is also covered with red-colored ferralitic soil, but much less rich in biological remains. A $1.50 \mathrm{~m}$ test pit excavated by the Norbert Casteret group in 1985 (Vento Canosa, 1990) 


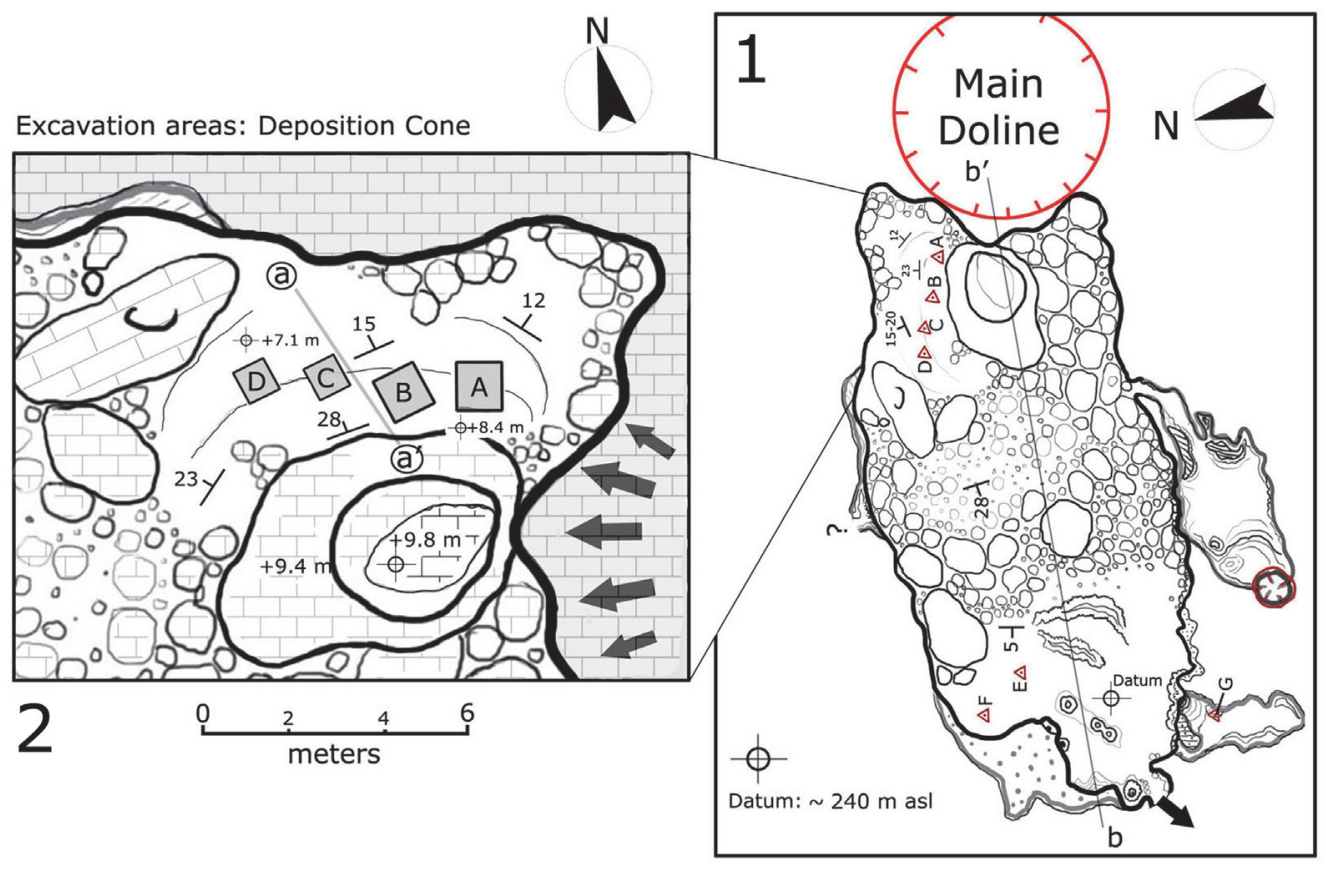

Cueva de los Nesofontes, Mayabeque, Cuba

3
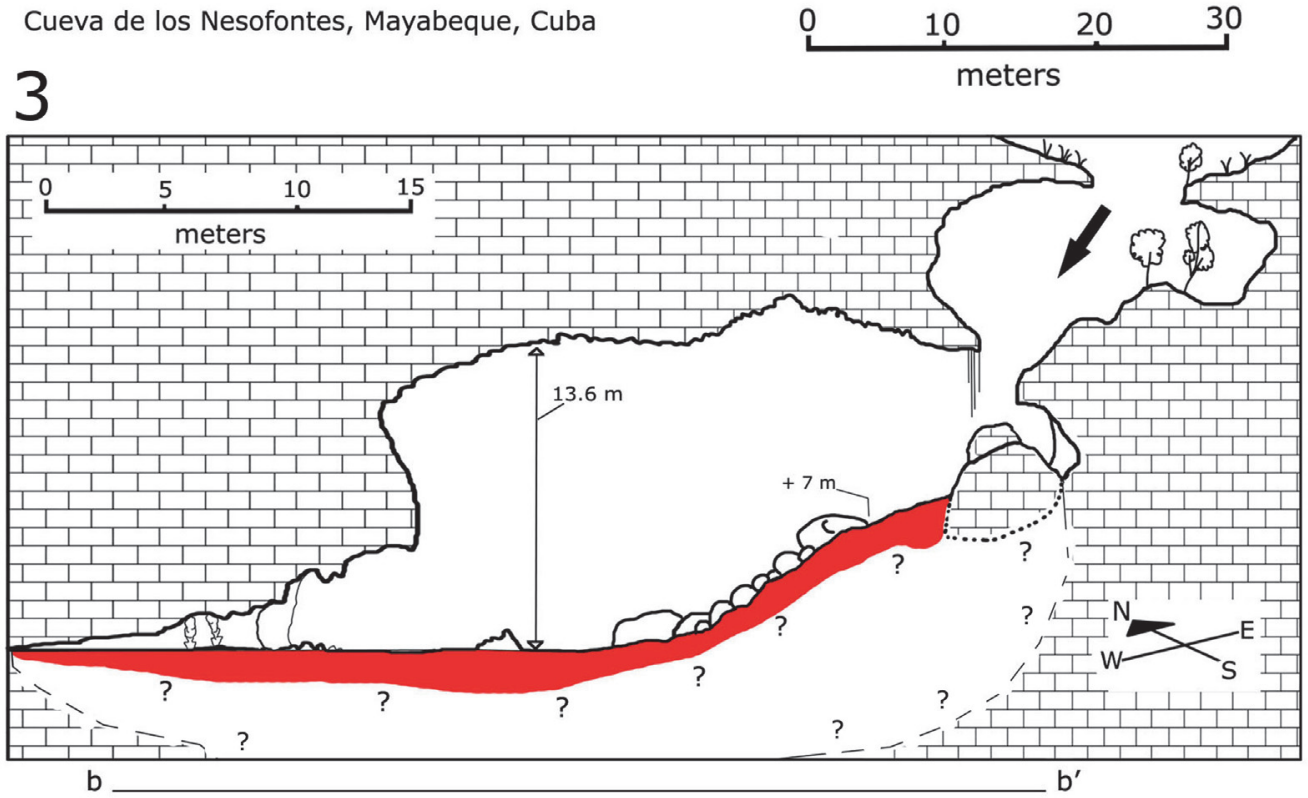

FIGURE 2. Cueva de los Nesofontes indicating geological, stratigraphic, and deposition features. 1, a gallery with main doline or sinkhole indicating areas of fauna collection. Smaller A-D letters pertain to the upper deposits/profiles described here. E-F are two test pits conducted on the lower level. $\mathrm{G}$ is the source location for the ${ }^{14} \mathrm{C}$-dated domestic dog mentioned in the text. 2, the upper area where the main test pits described are located: A is the test pit from 1985, B-C was dug between April 1995 and December 2003. The cross-section a-a' is the approximate source for the stratigraphic profiles illustrated in the following figures. Angles of inclination and heights above the main level are indicated. 3, cross-section (indicated b-b' on 1). Arrows indicate areas of sediment and raptor-derived pellet deposits and roost.

suggests that the deposit is deeper and similarly rich in fauna (Figure 3, profiles denoted A).

Although conclusive archaeological evidence has not been found in this gallery or its deposits, a ceramic fragment of unknown provenance has been recovered from the cave (Hernández de Lara et al., 2013), and a cave pictograph was recently discovered in Cueva del Campamento, situated 


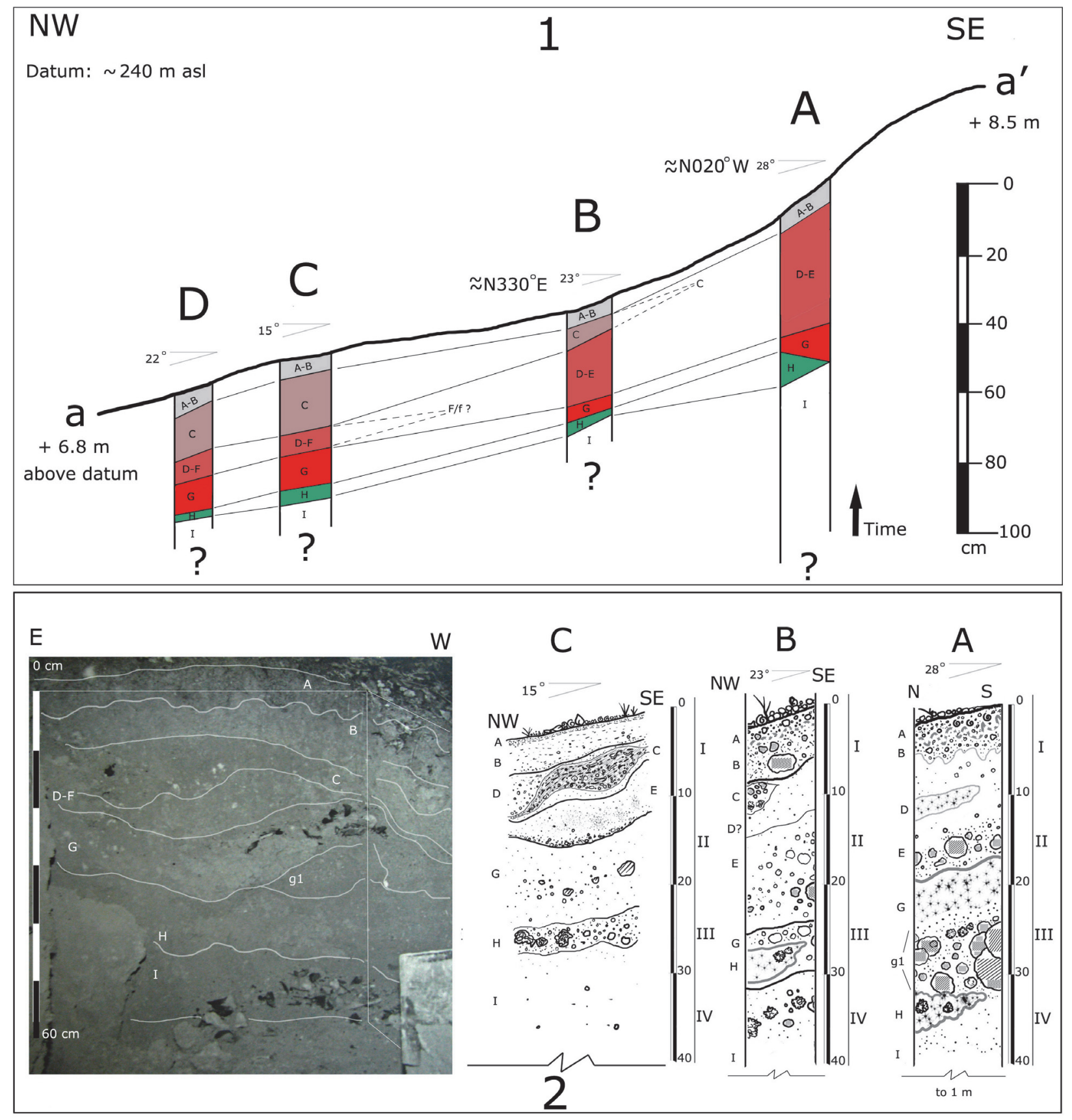

FIGURE 3. Stratigraphic profile composite, including all test pit excavations from cross-section a-a' illustrated in Figure 2. 1, indicates a graphic correlation of the stratigraphic units (profiles A-I) and their lenses (e-f). 2, shows the southern wall profile of the excavation of $1985(\mathrm{~A})$, whereas the A-profile on the extreme lower right, shows the east wall of the same profile. Profiles B-C pertains to the other test pits. Each Roman numeral indicates the arbitrary $10 \mathrm{~cm}$ excavation intervals. Depth, dip, and strike are included for the profiles.

nearly a hundred meters in the escarpment above the main sinkhole of Cueva de los Nesofontes (Orihuela and Pérez Orozco, 2015). This pictograph could have been made during aboriginal or maroon occupation, as the name of the hill and the region suggests, for a Palenque is an aboriginal or maroon hideout.

\section{Excavation Methods}

Four test pits were excavated between 1985 and 2003. All excavations were done with a trowel and small metal shovel. The first and deepest test pit was excavated in 1985 (Figures 2 and 3) and measured $1 \mathrm{~m}$ length by $1 \mathrm{~m}$ width and reached 
TABLE 1. Stratigraphic units, levels, and chronology from Cueva de los Nesofontes, Mayabeque, Cuba. Results and source of radiocarbon dated (AMS ${ }^{14} \mathrm{C}$ ) material with lab numbers is provided. The roman numbers indicate the stratigraphic interval, and the letter the stratigraphic unit, as discussed in the text.

\begin{tabular}{|c|c|c|c|c|c|c|c|}
\hline Interval & $\begin{array}{l}\text { Depth } \\
\text { (cm) }\end{array}$ & $\begin{array}{l}\text { Strat. } \\
\text { Unit }\end{array}$ & Granulometry & ${ }^{14} \mathrm{C}$ Cal yrs BP & $\begin{array}{l}\text { Cal yrs } \\
(2 \sigma)\end{array}$ & Source & Number \\
\hline I & $0-9$ & $A$ & $40.9 \%$ med sand & $1.223 \pm 0.004 \mathrm{pMC}$ & AD 1955-1993 & $\begin{array}{l}\text { Artibeus } \\
\text { jamaicensis } \\
\text { humerus }\end{array}$ & ICA 15B/0116 \\
\hline II & $10-19$ & E & $>50 \%$ med san & $1960 \pm 30 \mathrm{BP}$ & BC 40-AD 90 & Phyllops vetus skull & ICA 18B/0845 \\
\hline III & $20-29$ & $\mathrm{H}$ & $52.4 \%$ fine sand & $1290 \pm 30 \mathrm{BP}$ & AD 660-770 & A. anthonyi dentary & ICA 14B/1102 \\
\hline IV & $30-45$ & I & $49.8 \%$ fine sand & $1418 \pm 20 \mathrm{BP}$ & AD 605-655 & $\begin{array}{l}\text { Nesophontes major } \\
\text { dentary }\end{array}$ & Beta 392022 \\
\hline I & $0-2$ & $\mathrm{n} / \mathrm{a}$ & Fine sand/detritus & $115.9 \pm 0.6 \mathrm{pMC}$ & AD 1957-1993 & $\begin{array}{l}\text { A. jamaicensis } \\
\text { scapula }\end{array}$ & Beta 210380 \\
\hline I & Surface & $\mathrm{n} / \mathrm{a}$ & cave floor & $1.014 \pm 0.004 \mathrm{pMC}$ & AD 1955-1956 & $\begin{array}{l}\text { Canis lupus } \\
\text { familiaris vertebra }\end{array}$ & ICA15B/0115 \\
\hline
\end{tabular}

over $1 \mathrm{~m}$ in depth. The second had a similar measurement, but only $50 \mathrm{~cm}$ in depth. The last two test pits ( $C$ and $D$ in Figure 2.2) measured $50 \mathrm{~cm} \mathrm{x}$ $50 \mathrm{~cm} \times 50 \mathrm{~cm}$. These test pits followed $10 \mathrm{~cm}$ intervals with attention to the natural stratigraphy. The natural stratigraphy was identified from changes in soil coloration and faunal composition. Unconformities and erosional surfaces were detected from excavation profiles. All analyzed material was extracted in situ from the lateral profile into a glass vial. The data presented here originate only from test pit $D$.

The excavated material was dry sieved with a fine screen mesh $(0.3 \mathrm{~cm})$. From each sieved sample, a subsample collection was randomly placed in plastic bottles $\left(\sim 462 \mathrm{~cm}^{3}\right)$. This was later softly dry brushed in the lab to remove adhered matrix and soil and material separated following Silva Taboada (1974) but including juveniles and other parts of the appendicular skeleton in the tallies following the method described in Orihuela (2010). This constituted the sample collection from which species diversity was calculated.

\section{Stratigraphy and Sedimentology}

Stratigraphic units were defined by dry color changes and changes in clast or debris size. Colors were defined using a Geological Society of America (GSA) Geological Color Chart (Geological Society of America, 2009) with a Munsell color system. The grain size was determined in the lab using USA Standard Sieves (no. 7, $2.80 \mathrm{~mm}$; no. 45, $0.355 \mathrm{~mm}$; no. 230, $0.0025 \mathrm{~mm}-63 \mu \mathrm{m}$ ) placed in sequence to extract clasts from silt-clay size up to fine gravel. Percentages were calculated from bulk fraction by weight. Interval I weighed $225.7 \mathrm{~g}$;
II: $30.0 \mathrm{~g}$; III: $225 \mathrm{~g}$; and IV: $29.8 \mathrm{~g}$. The weights were measured with an Accuris Analytical balance.

Nine levels of natural deposition (beds) were generally identified at all test pits (denoted $A$ through I, from top to bottom). Because of the dip angle of the deposit, two to three of these beds were usually present within each of the $10 \mathrm{~cm}$ excavation intervals. These intervals are indicated as levels I through IV, from top to bottom. Several beds pinched out or appeared laterally tapered as facies or lenses and are indicated with lower case letters (Figure 3).

The distinctive layers had sharp contacts with changes in coloration, which graded from the dark dusky yellow green-moderate reds of bed $A$ and $B$ (10 YR 4/2, $10 \mathrm{R} \mathrm{6/2-10} \mathrm{R} \mathrm{6/4)} \mathrm{to} \mathrm{the} \mathrm{reddish}$ oranges and moderate dusky reds (5 Y 8/4-10 R 6/ $6-5 R 3 / 4$ ) of beds $D$ to $E$. Beds were generally rill eroded, poorly sorted, with poorly rounded or subangular clasts, medium-fine sand, granules, and coarse pebbles (Table 1). Bed thickness ranged between thin and thick (5 $\mathrm{mm}$ to $15 \mathrm{~cm}$ layers). Beds A, B, G through I, were near planar, wavy non-parallel, well and grade-bedded, with dip angles between 22 and 28 degrees in the main slope, but less than $3^{\circ}$ at the lowest floor level of the gallery (Figure 3 ).

The beds were separated by sharp contacts or boundaries (i.e., disconformity/erosional surfaces), especially between beds $C, D, E$, and $F$. Layers $A, B$, and $G-1$ were generally conformant or paracomformant (i.e., of undiscernible unconformities). Bed C constituted a large first-order ash bed with fragments of charcoal, wood detritus, coarse clasts, abundant fossils, and gastropod shells (ash made up $>30 \%$ composition). This layer contained 


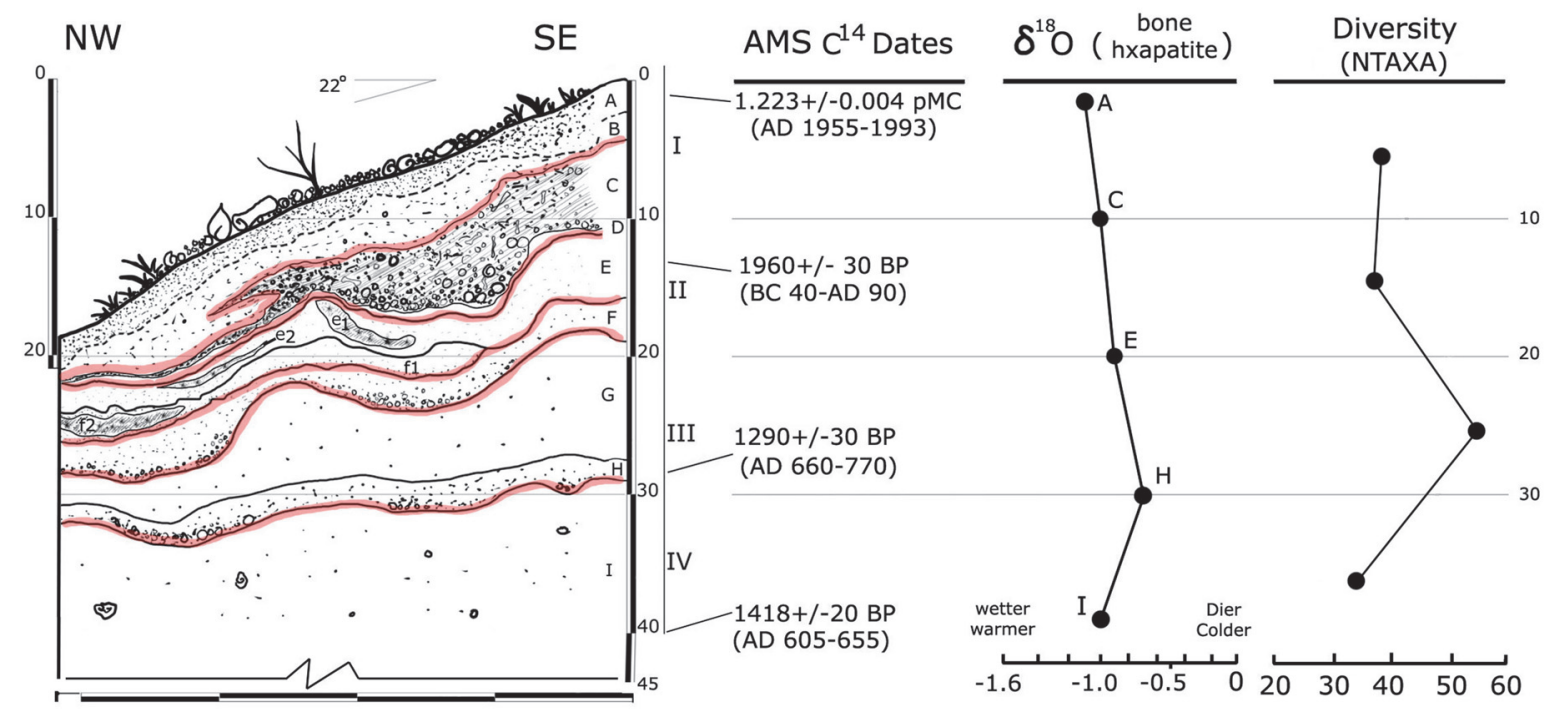

FIGURE 4. Lateral profile of test pit $D$ with source radiocarbon dates, oxygen stable isotopes, and NTAXA diversity by intervals. The fauna and multi-proxy analyses described in the text are from this excavation. The red lines indicate the major disconformities/erosional surfaces.

exotic species such as murids and the domestic European sparrow (Passer domesticus). The beds $\mathrm{H}-\mathrm{I}$ formed the largest paracomformity with unidentifiable layers below the $\sim 50 \mathrm{~cm}$ depth (Level IV) (Figures 3-4).

Most beds were correlated between test pits (Figure 3). Others, such as bed E, F, and G included small lenses (e1, e2, f1, f2, and g1), that graded laterally or pinched out up-slope. Bed C also pinched out towards the higher parts of the deposition zone, where $\mathrm{H}$ also seemed to disappear, at least laterally (Figure $3 \mathrm{~A}$ and $\mathrm{B}$ profiles).

\section{Multifaceted Analytical Approaches}

For elemental analysis, high-resolution imaging, and characterization of cave soils and loams we used a JEOL JSM 5900LV scanning electron microscope (SEM) with energy dispersive spectroscopy EDS-UTW with detectors of $3.0 \mathrm{~nm}$ resoIution at the Florida Center for Analytical Electron Microscopy (FCAEM) facility at Florida International University (Miami, FL). Soil or fossil fragments selected for analysis were placed in separate stages, and each sample was analyzed three times. The averages are reported in weight percentage (wt \%) of those measurements. These analyses allowed for the identification of clay particles, other clasts content, and the overall elemental composition of the red clay soils. These analyses were conducted without coating, directly on dry samples kept in sterile glass vials collected in situ. For microscope and thin-section analysis, a Leica
DM EP petrographic microscope was used. The samples were prepared at Florida International University.

Radiocarbon dating ${ }^{14} \mathrm{C}$ AMS (accelerator mass spectrometry) and several of the isotope analyses (for nitrogen and carbon) were conducted by Beta Analytic Inc. (Miami, FL), and International Chemical Analysis Inc. (ICA, Ft. Lauderdale, FL), following each lab's standard procedure and who reported no complications (D. Wood, R. Hatfield, and B. Díaz, personal commun., 2014-2018). The dates and most isotope values were determined from bone collagenun. These are reported using the standard notation of radiocarbon years before the present (rcyr BP). Carbon younger in age than the modern reference standards is reported as "Percent Modern Carbon" (pMC), which indicate a date after thermonuclear testing, and date after the 1950s (Hua and Barbettii, 2004).

The conventional ${ }^{14} \mathrm{C}$ AMS dates were calibrated to calendar age-intercept solar years (cal. $\mathrm{yr})$ to one and two sigma ranges $( \pm 1 \sigma-2 \sigma)$ using Oxcal v4.3, on IntCal13 carbon curve for the Northern Hemisphere, see Ramsey (2017). Only values that differed less than 140 years were considered contemporaneous (Semken et al., 2010), although the rule of thumb may extend up to \pm 200 years due to multiple intercepts and conversion curve topography on dates during the last 2000 years (Geyh and Schleicher, 1990). Late Quaternary epochs and time intervals discussed follow Morgan and 
Woods (1986), Soto-Centeno et al. (2015), and limits established by the IUGS (International Union of Geological Sciences).

Additional isotope analyses were conducted at the Stable Isotope Ratio Mass Spectrometry Facility at the University of South Florida (USF, Tampa). These analyses were conducted to explore the paleoenvironment and diet that could be interpreted from isotope signals (Bocherens et al., 1996; Ben-David and Flaherty, 2012). Such additional data could help elucidate aspects of competition and habitat selectivity between some of the species analyzed.

Carbon $(\mathrm{C})$, oxygen $(\mathrm{O})$, and nitrogen $(\mathrm{N})$ isotope values were determined from bone apatite and collagen, and their rations reported in delta $(\delta)$ standard notation: ${ }^{13} \mathrm{C} /{ }^{12} \mathrm{C}=\delta^{13} \mathrm{C} \_$apt. for carbon acquired from apatite and $\delta^{13} \mathrm{C} \_$col. when acquired from bone collagen. The same applies to nitrogen: ${ }^{14} \mathrm{~N} /{ }^{15} \mathrm{~N}=\delta^{15} \mathrm{~N} \_$apt. (apatite) and $\delta^{15} \mathrm{~N} \_$col. (bone collagen). The carbon from apatite is reported in parts per mil (\%) compared to the Vienna Pee Dee Belemnite (VPDB) and nitrogen from atmospheric nitrogen (AIR) (Bocherens et al., 1996). Oxygen values, ${ }^{18} \mathrm{O} / 17 \mathrm{O}=\delta^{18} \mathrm{O}$, were acquired from tooth apatite of Artibeus jamaicensis remains, and are reported also as a ratio of VDPB parts per mil (\%o) (Table 2). These values likely originate from available drinking water or water in the fruits consumed by the Artibeus bats, and thus provides a regional paleoclimatic proxy (Bocherens et al., 1996; BenDavid and Flaherty, 2012). The C: $\mathrm{N}$ ratio used to indicate diagenesis or alteration in the collagen sample was always $<3.4$, suggesting insignificant or no diagenesis on the analyzed remains (DeNiro,
1985; Bocherens et al., 1996; Ben-David and Flaherty, 2012).

\section{Taphonomic and Fauna Methodologies}

The weathering levels, based on a numerical value representative of bone erosion, flaking, or fracturing due to atmospheric exposure follow Behrensmeyer (1978), Shipman (1981), and Andrews (1990). The bioturbation index follows Taylor and Goldring (1993). Estimation of taxonomic abundance, diversity, and their indices follow Lyman (2008).

Anatomical terminology for birds follows Howard (1929), Olsen (1979), and for mammals Silva Taboada et al. (2007). The systematic taxonomy of Cuban rodents follows Silva Taboada et al (2007). For Nesophontes we follow Rzebik-Kowalska and Woloszyn (2012) and our work in preparation in considering three valid species in Cuba. The validity of Nesophontes micrus and N. major are furthermore supported by proteomics (Buckley et al., 2020). For extant Cuban birds, we followed Garrido and Kirkconnell (2000), González Alonso (2012), and Orihuela (2019) for extinct birds.

Fauna and faunal variations discussed here only pertain to test pit $D$. We infer that Pit $D$ does not differ from the others, which were slightly less diverse, but similarly rich in Nesophontes spp (JO unpublish data). Tables 3 and 4 provide a synthesis of the fauna present in the Pit $D$ assemblage. Moreover, Table 4 provides a stratigraphic distribution of taxa within each of the levels and beds of Pit $D$. The fauna we will discuss ahead pertain to only species that are noteworthy or represent extralimital records.

Specimens were compared and identified with neontological and fossil collections at $\mathrm{AMNH}$, the

TABLE 2. Results of stable isotope analysis with source material from deposits at Cueva de los Nesofontes. " $"$ ": Approximate source depth for analyzed specimens. "n/a": Not available data. "collagen": Collagen-derived measurement (those not indicated are from dental apatite readings).

\begin{tabular}{|c|c|c|c|c|c|c|}
\hline Interval & $\begin{array}{l}\text { Depth } \\
\text { (cm) }\end{array}$ & $\begin{array}{l}\text { Strat. } \\
\text { Unit }\end{array}$ & $\delta^{18}$ O_apt & $\delta^{13} \mathrm{C}$ & Source & Number \\
\hline I & 0 & A & -1.1 & -9.9 & Artibeus jamaicensis skull & USF 15314 \\
\hline I & 0 & $A$ & $\mathrm{n} / \mathrm{a}$ & -20.1 (collagen) & A. jamaicensis humerus & ICA 15B/0116 \\
\hline I-II & $\sim 14$ & C & -1 & -8.1 & A. jamaicensis humeri & USF 15316 \\
\hline II & $\sim 18$ & E & -0.9 & -10 & A. jamaicensis skull & USF 15313 \\
\hline III-IV & 29-31 & $\mathrm{H}$ & -0.7 & -11.0 & A. anthonyi dentary & USF 15315 \\
\hline III-IV & $29-32$ & $\mathrm{H}$ & $\mathrm{n} / \mathrm{a}$ & -21.1 (collagen) & A. anthonyi dentary & ICA 14B/1102 \\
\hline IV & $>32$ & 1 & -1 & -20.7 (collagen) & Nesophontes major dentary & Beta 392022 \\
\hline I & $0-2$ & $\mathrm{n} / \mathrm{a}$ & $\mathrm{n} / \mathrm{a}$ & -20.7 (collagen) & A. jamaicensis scapula & Beta 210380 \\
\hline I & Surface & $\mathrm{n} / \mathrm{a}$ & $\mathrm{n} / \mathrm{a}$ & -10.9 (collagen) & Canis Iupus familiaris vertebra & ICA15B/0115 \\
\hline
\end{tabular}


TABLE 3 (continued on two pages). Cueva de los Nesofontes fauna list, providing several individual specimens (NISP), the minimum number of individuals (MNI), and the number of total taxa (NTAXA) counts.

\begin{tabular}{|c|c|c|c|}
\hline Species & NISP & MNI & NTAXA \\
\hline \multicolumn{4}{|l|}{ Amphibians } \\
\hline Eleuterodactylus sp. 1 & 14 & 10 & 1 \\
\hline Eleuterodactylus sp. 2 & 2 & 2 & 1 \\
\hline Eleuterodactylus sp. 3 & 3 & 1 & 1 \\
\hline Peltophryne sp. & 1 & 1 & 1 \\
\hline Total & 20 & 14 & 4 \\
\hline \multicolumn{4}{|l|}{ Reptiles } \\
\hline Anolis cf. equestris & 2 & 1 & 1 \\
\hline Anolis sagrei & 4 & 1 & 1 \\
\hline Anolis sp. (Large) & 2 & 1 & 1 \\
\hline Anolis cf. chamaleonides & 14 & 1 & 1 \\
\hline Total & 22 & 4 & 4 \\
\hline \multicolumn{4}{|l|}{ Aves } \\
\hline Cathartes aura & 3 & 2 & 1 \\
\hline Falco sparverius & 1 & 1 & 1 \\
\hline Sphyrapicus varius & 3 & 1 & 1 \\
\hline Melanerpes superciliaris & 4 & 2 & 1 \\
\hline Colaptes sp. cf. fernandinae/auratus & 2 & 2 & 1 \\
\hline Saurothera merlini & 1 & 1 & 1 \\
\hline Crotophaga ani & 2 & 2 & 1 \\
\hline Psittacara eups & 1 & 1 & 1 \\
\hline Psittasidae gen. et sp. indent. & 1 & 1 & 1 \\
\hline Tyto furcata & 2 & 2 & 1 \\
\hline Glaucidium siju & 1 & 1 & 1 \\
\hline Margarobyas lawrencii & 11 & 5 & 1 \\
\hline Strigidae gen. et sp. indet. (medium size) & 1 & 1 & 1 \\
\hline Strigidae gen. et sp. indet. (large size) & 1 & 1 & 1 \\
\hline Zenaida asiatica or macrura & 3 & 2 & $2 ?$ \\
\hline Zenaida aurita & 4 & 1 & 1 \\
\hline Geotrygon cf. chrysia & 1 & 1 & 1 \\
\hline Nesotrochis picapicensis & 1 & 1 & 1 \\
\hline Corvus sp. indet. & 1 & 1 & 1 \\
\hline Tyrannus sp. cf. dominicensis & 1 & 1 & 1 \\
\hline Turdus plumbeus & 3 & 1 & 1 \\
\hline Dumetella carolinesis & 3 & 2 & 1 \\
\hline Mimus polygottos & 11 & 3 & 1 \\
\hline Mimidae gen. et. sp. indet. & 2 & 1 & 1 \\
\hline Progne cf. cryptoleuca & 1 & 1 & 1 \\
\hline
\end{tabular}

American Museum of Natural History, New York, USA; UF-FLMNH, the Museum of Natural History of the University of Florida, Gainesville, Florida, USA; IES, the Institute of Ecology and Systematics, La Habana, Cuba; and the zoological collection of Gabinete de Arqueológia, Office of the Conservator of the city of La Habana, Cuba. All the remains analyzed were extracted with permission of the Central Registry of National Cultural Goods (certification no. 20141965; LHA-23, fol. 0162773). 
TABLE 3 (continued).

\begin{tabular}{|c|c|c|c|}
\hline Species & NISP & MNI & NTAXA \\
\hline Tachycineta bicolor & 2 & 2 & 1 \\
\hline Dives atroviolasceous & 10 & 9 & 1 \\
\hline Quiscalus niger & 10 & 5 & 1 \\
\hline Icterus sp. indet. & 3 & 1 & 1 \\
\hline Agelaius sp. indet. & 1 & 1 & 1 \\
\hline Icteridae gen. et sp. indet. (small size) & 2 & 1 & 1 \\
\hline Sturnella magna & 1 & 1 & 1 \\
\hline Passer domesticus & 10 & 5 & 1 \\
\hline Falco sparverius & 1 & 1 & 1 \\
\hline Aves gen. et sp. indet. & 3 & 3 & 0 \\
\hline Total & 103 & 64 & 33 \\
\hline \multicolumn{4}{|l|}{ Rodents } \\
\hline Rattus rattus & 3 & 2 & 1 \\
\hline Rattus norvegicus & 18 & 5 & 1 \\
\hline Mus musculus & 6 & 3 & 1 \\
\hline Boromys torreii & 131 & 15 & 1 \\
\hline Boromys offella & 13 & 5 & 1 \\
\hline Geocapromys columbianus & 10 & 5 & 1 \\
\hline Capromys pilorides & 21 & 5 & 1 \\
\hline Mesocapromys nanus & 3 & 2 & 1 \\
\hline Mesocapromys kraglievichi & 4 & 4 & 1 \\
\hline Mesocapromys sp. indet. & 19 & 10 & 0 \\
\hline Mesocapromys gen. indet. & 24 & 2 & 0 \\
\hline Total & 252 & 58 & 9 \\
\hline \multicolumn{4}{|l|}{ Eulipotyphla } \\
\hline Solenodon cubanus & 3 & 2 & 1 \\
\hline Nesophontes micrus & 628 & 62 & 1 \\
\hline Nesophontes major & 403 & 64 & 1 \\
\hline Nesophontes cf. longirostris & 3 & 2 & 1 \\
\hline Total & 1037 & 130 & 4 \\
\hline
\end{tabular}

All the remains from these and other excavations are deposited in the collection of the Museo Nacional de Historia Natural (MNHNCu), in La Habana, Cuba. Part of the collection has been cataloged (Donation 13.18: MNHNCu-72-05.01 and 76156-215), but the rest remains uncatalogued (E. Aranda, personal commun., 2016, 2018).

Measurements were taken with a digital caliper and are reported in millimeters $(\mathrm{mm})$. All statistical analyses were conducted with PAST, a Paleontological statistics software package, version 3 (Hammer et al., 2001).

\section{RESULTS}

\section{Radiocarbon Chronology and Sedimentation Rates}

Four radiocarbon dates $\left({ }^{14} \mathrm{C}\right.$ AMS) were acquired from the four stratigraphic intervals of test pit $D$ (Table 1; Figure 4). For the upper level (I), a fresh Artibeus jamaicensis adult humerus was selected from bed A. For Level II, a skull of the extinct bat Phyllops vetus from bed E. From lowermost (near interface) level III, a dentary of the extinct bat Artibeus anthonyi from bed $\mathrm{H}$, and for level IV, a dentary of the extinct shrew Nesophontes major from bed I. These last three radiocarbon 
TABLE 3 (continued).

\begin{tabular}{lccc}
\hline \multicolumn{1}{c}{ Species } & NISP & MNI & NTAXA \\
\hline Chiroptera & 10 & 5 & 1 \\
Mormoops blainvilleii & 4 & 2 & 1 \\
Pteronotus parnellii & 61 & 13 & 1 \\
Brachyphylla nana & 2 & 1 & 1 \\
Monophyllus redmani (clinedaphus) & 11 & 4 & 1 \\
Erophylla sezekorni & 88 & 55 & 1 \\
Phyllonycteris poeyi & 33 & 12 & 1 \\
Macrotus waterhouseii & 8 & 3 & 1 \\
Artibeus anthonyi & 21 & 10 & 1 \\
Artibeus jamaicensis (larger size) & 475 & 165 & 1 \\
Artibeus jamaicensis (parvipes) & 49 & 18 & 1 \\
Phyllops falcatus & 21 & 8 & 1 \\
Phyllops vetus & 1 & 1 & 1 \\
Natalus primus & 7 & 4 & 1 \\
Antrozous koopmani & 45 & 15 & 1 \\
Eptesicus fuscus (dutertreus) & 30 & 15 & 1 \\
Tadarida brasiliensis & 4 & 4 & 1 \\
Molossus molossus & 15 & 2 & 1 \\
Chiroptera gen. et. sp. indet. & 871 & 335 & 17 \\
Total & & &
\end{tabular}

dates represent the first direct LADs reported for these Cuban species.

The uppermost bed $(A)$ yielded a modern carbon age between AD 1955 and 1993, and thus a very modern age for this level. The date for bed $E$, between $B C 40$ and $A D 90$ revealed an inversion event in the stratigraphy or reworking of older remains since the lower levels yielded younger dates between AD 605-655 and AD 660-770 (Figures 3, 4; Table 1).

An additional date was acquired for a domestic dog (Canis lupus familiaris) skeleton found mineralized in the floor of a small room at the entrance of the doline gallery (Figure 2.1, collection station G; Tables 1-2). Originally, this specimen was considered pre-Columbian in age and was thus selected for testing. However, the age it yielded indicated its deposition within the modern period AD 1957-1993 and is likely contemporaneous with bed $A$ of the cone deposit above. A similar surface radiocarbon date from this cave, albeit a different deposit, is provided in Orihuela (2010). All these superficial tests help support that the uppermost levels of the cave's deposit are generally modern (i.e., post-Columbian). But the presence of extinct taxa such as Nesophontes there too, suggests likely partial reworking.
All dates suggest ample hiatuses of several hundred years between beds/intervals (Figure 4). These had slow sedimentation rates that varied between $1.15 \mathrm{~mm} / \mathrm{yr}$ at the upper level (beds $\mathrm{A}-\mathrm{C}$ ), and slightly faster rates $>1.30 \mathrm{~mm} / \mathrm{yr}$ for the middle levels (beds $\mathrm{C}-\mathrm{E}$ ), and $1.28 \mathrm{~mm} / \mathrm{yr}$ for the lower III-IV, beds $\mathrm{H}$ and I. Additional dates for these intervals are presented in Orihuela et al. (2020a).

\section{Stable Isotopes}

Stable isotopes of carbon $\left(\delta^{13} \mathrm{C}\right)$ and oxygen were measured from apatite $\left(\delta^{13} \mathrm{C} \_\right.$apt. $)$and bone collagen $\left(\delta^{13} \mathrm{C} \_\right.$col. $)$of four adult specimens of the fruit bat $A$. jamaicensis, plus one adult specimen of the extinct bat $A$. anthonyi and a newborn Canis lupus familiaris (the same which were ${ }^{14} \mathrm{C}$ dated; Table 1). Moreover, oxygen and carbon isotopic values were acquired from four $A$. jamaicensis dental apatite samples from each interval (Table 2).

An additional analysis of nitrogen $\left(\delta^{15} \mathrm{~N} \_c o l.\right)$ and carbon $\left(\delta^{13} \mathrm{C} \_c 0 l.\right)$ isotopes were obtained from the bone collagen of the ${ }^{14} \mathrm{C}$ dated $N$. major (Table 2). This specimen yielded a value of $-20.7 \%$ $\delta^{13} \mathrm{C} \_$col. and of $7.9 \% \circ \delta^{15} \mathrm{~N} \_c o l$. These data help approximate the diet of these vertebrates and pro- 
TABLE 4 (continued on next two pages). Stratigraphic distribution of taxa throughout each interval and their count. Presence is indicated with an ' $x$ ' and empty cell reports an absence. A total by interval is provided.

\begin{tabular}{|c|c|c|c|c|}
\hline $\begin{array}{c}\text { Species Stratigraphy } \\
\text { Level } \\
\text { Beds (Stratigraphic units) }\end{array}$ & $\begin{array}{c}\text { I }(0-10 \mathrm{~cm}) \\
\text { A-C }\end{array}$ & $\begin{array}{c}\text { II }(11-20 \mathrm{~cm}) \\
\text { B-F }\end{array}$ & $\begin{array}{c}\text { III }(21-30 \mathrm{~cm}) \\
\mathrm{F}-\mathrm{H}\end{array}$ & $\begin{array}{c}\text { IV }(31-50 \mathrm{~cm}) \\
\mathrm{H}-\mathrm{I}\end{array}$ \\
\hline \multicolumn{5}{|l|}{ Amphibians } \\
\hline Eleuterodactylus sp. 1 & $\mathrm{x}$ & $x$ & $\mathrm{x}$ & $\mathrm{x}$ \\
\hline Eleuterodactylus sp. 2 & & $x$ & $x$ & \\
\hline Eleuterodactylus sp. 3 & $x$ & $x$ & $x$ & \\
\hline Peltophryne sp. & & & & $\mathrm{x}$ \\
\hline Total Taxa per bed & 2 & 3 & 3 & 2 \\
\hline \multicolumn{5}{|l|}{ Reptiles } \\
\hline Anolis cf. equestris & & & $x$ & $x$ \\
\hline Anolis sagrei & $\mathrm{x}$ & $x$ & $\mathrm{x}$ & \\
\hline Anolis sp. (Large) & & & $x$ & $x$ \\
\hline Anolis cf. chamaleonides & $x$ & & & \\
\hline Total Taxa per bed & 2 & 1 & 3 & 2 \\
\hline \multicolumn{5}{|l|}{ Aves } \\
\hline Cathartes aura & $x$ & & $x$ & \\
\hline Falco sparverius & $\mathrm{x}$ & & & \\
\hline Sphyrapicus varius & & $x$ & $x$ & \\
\hline Melanerpes superciliaris & $x$ & & & $x$ \\
\hline Colaptes sp. cf. fernandinae/auratus & & & & $\mathrm{x}$ \\
\hline Saurothera merlini & & & $x$ & \\
\hline Crotophaga ani & $x$ & & $x$ & \\
\hline Psittacara eups & & & $\mathrm{x}$ & \\
\hline Psittasidae gen. et sp. indent. & $x$ & & & \\
\hline Tyto furcata & $x$ & & $x$ & \\
\hline Glaucidium siju & & & $\mathrm{x}$ & \\
\hline Margarobyas lawrencii & $x$ & $x$ & $x$ & $x$ \\
\hline $\begin{array}{l}\text { Strigidae gen. et sp. indet. (medium } \\
\text { size) }\end{array}$ & & $x$ & & $\mathrm{x}$ \\
\hline Strigidae gen. et sp. indet. (large size) & & & & $x$ \\
\hline Zenaida asiatica or macrura & & $x$ & $x$ & \\
\hline Zenaida aurita & & $x$ & $x$ & \\
\hline Geotrygon cf. chrysia & & & $x$ & \\
\hline Nesotrochis picapicensis & & & & $x$ \\
\hline Corvus sp. indet. & & & $x$ & \\
\hline Tyrannus sp. cf. dominicensis & $\mathrm{x}$ & & & \\
\hline Turdus plumbeus & & & $x$ & $\mathrm{x}$ \\
\hline Dumetella carolinesis & & $x$ & $x$ & \\
\hline Mimus polygottos & & $x$ & $x$ & $x$ \\
\hline Mimidae gen. et. sp. indet. & & $x$ & & \\
\hline Progne cf. cryptoleuca & & & $x$ & \\
\hline Tachycineta bicolor & & & $x$ & \\
\hline Dives atroviolasceous & $x$ & $x$ & $x$ & $x$ \\
\hline Quiscalus niger & $x$ & & & \\
\hline
\end{tabular}


TABLE 4 (continued).

\begin{tabular}{|c|c|c|c|c|}
\hline \multicolumn{5}{|l|}{ Species Stratigraphy } \\
\hline Level & $\mathrm{I}(0-10 \mathrm{~cm})$ & II $(11-20 \mathrm{~cm})$ & III $(21-30 \mathrm{~cm})$ & IV $(31-50 \mathrm{~cm})$ \\
\hline Beds (Stratigraphic units) & A-C & B-F & F-H & H-I \\
\hline Icterus sp. indet. & & & $x$ & $x$ \\
\hline Agelaius sp. indet. & & & $\mathrm{x}$ & \\
\hline Icteridae gen. et sp. indet. (small size) & $x$ & $x$ & $x$ & \\
\hline Sturnella magna & $x$ & & & \\
\hline Passer domesticus & $x$ & $\mathrm{x}$ & & \\
\hline Aves gen. et sp. indet. & $x$ & & $\mathrm{x}$ & $x$ \\
\hline Total Taxa per bed & 14 & 11 & 22 & 11 \\
\hline \multicolumn{5}{|l|}{ Rodents } \\
\hline Rattus rattus & $x$ & $x$ & $x$ & $x$ \\
\hline Rattus norvegicus & $x$ & $x$ & $x$ & $x$ \\
\hline Mus musculus & $x$ & $x$ & $x$ & \\
\hline Boromys torreii & $x$ & $x$ & $x$ & $x$ \\
\hline Boromys offella & & & $x$ & $x$ \\
\hline Geocapromys columbianus & & & $\mathrm{x}$ & $x$ \\
\hline Capromys pilorides & $x$ & $x$ & $x$ & $x$ \\
\hline Mesocapromys nanus & & & $x$ & $x$ \\
\hline Mesocapromys kraglievichi & & $x$ & $\mathrm{x}$ & $x$ \\
\hline Mesocapromys sp. indet. & & $x$ & $x$ & $x$ \\
\hline Total taxa per bed & 5 & 7 & 10 & 9 \\
\hline \multicolumn{5}{|l|}{ Eulipotyphla } \\
\hline Solenodon cubanus & $x$ & $x$ & & \\
\hline Nesophontes micrus & $x$ & $x$ & $x$ & $x$ \\
\hline Nesophontes major & $x$ & $x$ & $x$ & $x$ \\
\hline Nesophontes cf. longirostris & & $x$ & $x$ & \\
\hline Total Taxa per bed & 3 & 4 & 3 & 2 \\
\hline \multicolumn{5}{|l|}{ Chiroptera } \\
\hline Mormoops blainvilleii & $x$ & & $x$ & \\
\hline Pteronotus parnellii & $x$ & $x$ & & \\
\hline Brachyphylla nana & $x$ & $x$ & $x$ & $x$ \\
\hline Monophyllus redmani (clinedaphus) & $x$ & & $x$ & \\
\hline Erophylla sezekorni & $x$ & $x$ & $x$ & \\
\hline Phyllonycteris poeyi & $x$ & $\mathrm{x}$ & $\mathrm{x}$ & $\mathrm{x}$ \\
\hline Macrotus waterhouseii & $x$ & $x$ & $x$ & \\
\hline Artibeus anthonyi & & & $x$ & $\mathrm{x}$ \\
\hline Artibeus jamaicensis (larger size) & & & $x$ & $x$ \\
\hline Artibeus jamaicensis (parvipes) & $x$ & $x$ & $x$ & $x$ \\
\hline Phyllops falcatus & $\mathrm{x}$ & & $x$ & \\
\hline Phyllops vetus & & $\mathrm{x}$ & $x$ & $\mathrm{x}$ \\
\hline Natalus primus & & $x$ & & \\
\hline Antrozous koopmani & & $x$ & $x$ & $x$ \\
\hline Eptesicus fuscus (dutertreus) & $x$ & $x$ & $\mathrm{x}$ & \\
\hline Tadarida brasiliensis & $x$ & & & \\
\hline
\end{tabular}


TABLE 4 (continued).

\begin{tabular}{|c|c|c|c|c|}
\hline \multicolumn{5}{|l|}{ Species Stratigraphy } \\
\hline Level & $\mathrm{I}(0-10 \mathrm{~cm})$ & II $(11-20 \mathrm{~cm})$ & III $(21-30 \mathrm{~cm})$ & IV $(31-50 \mathrm{~cm})$ \\
\hline Beds (Stratigraphic units) & $A-C$ & B-F & F-H & $\mathrm{H}-\mathrm{I}$ \\
\hline Molossus molossus & $x$ & & & \\
\hline Chiroptera gen. et. sp. indet. & $x$ & $x$ & $x$ & $x$ \\
\hline Total Taxa per bed & 13 & 11 & 14 & 8 \\
\hline \multicolumn{5}{|l|}{ Total } \\
\hline Mammals & 21 & 22 & 27 & 19 \\
\hline Vertebrates & 39 & 38 & 55 & 34 \\
\hline $\begin{array}{l}\text { Vertebrates plus Gastropods and } \\
\text { Crustaceans }\end{array}$ & 51 & 54 & 63 & 41 \\
\hline
\end{tabular}

vide insight into the paleoenvironments and taphonomy, as are interpreted in the Discussion section.

\section{Taxon Identification and Fauna Sample}

A total of 3932 specimens were collected from the assemblage (test Pit D), of which 2326 (59.2 $\%)$ were identifiable vertebrate specimens (NISP) and 324 were unidentifiable fragments. The NISP increased to 2870 if invertebrates were included (Table 3). Another 738 specimens were collected from two other surface deposits within the cave near the deposit (Figure 2). The total, including invertebrates, represented 83 taxa (NTAXA).

Of the total NTAXA $(n=83), 71$ taxa represented vertebrates, yielding a count of 602 minimum number of identified individuals (MNI) (Table 3 ). This fauna was mostly composed of birds (33 species) and mammals ( 232 species), $39.8 \%$, and $38.6 \%$ of the total NTAXA, respectively. Of the birds, the woodpeckers (at least 3 taxa or $9 \%$ ), the strigids (at least 3 ), pigeons (at least 3 ), and passerines (7 or $21 \%$ ), were the most abundant.

Within the mammals, the bats and eulipotyphlans were the most abundant, but the rodents and bats were the most diverse (Table 3 ). NTAXA vertebrate diversity increases to 77 if other species records from the surface collections and other excavated deposits within the cave are added. These include, for instance, the bats Desmodus rotundus, Chilonatalus macer, and Lasiurus insularis (Orihuela, 2010; Orihuela et al., 2020a, 2020b).

The gastropod fauna was diverse with at least nine species preliminarily recorded. Further identification of their remains will likely increase the overall NTAXA count. The gastropods, amphibians, and reptiles will not be discussed in detail here. These groups of organisms have been poorly studied in Cuban Quaternary deposits, and thus our knowledge of them in the recent past is very limited. In the case of the amphibians and reptiles, this has been largely dictated by a lack of modern comparative osteological material in the Cuban zoological collections (Aranda, 2019). However, those that we could identify (Table 3 ) will be briefly commented on in the Discussion, and altogether add to the knowledge of the island's past herpetofauna.

\section{Systematic Palaeontology: Noteworthy or Extralimital Record Fauna}

Class AVES Linnaeus, 1758

Order CATHARTIFORMES Coues, 1884

Family CATHARTIDAE Lafresnaye, 1839

Genus CATHARTES Illiger, 1811

Cathartes aura (Linnaeus, 1758)

Figure 5.1

Material. One left femur (MNHNCu uncatalogued, field no. 582a) and a complete skull (MNHNCu uncatalogued, field no. 582b) without mandible from bed $A$ (level I), and one incomplete premaxilla (MNHNCu uncatalogued, field no. 193) from bed $G$ (level III) (Figure 5.1). A complete skeleton with evidence of anthropogenic combustion was found at the lower part of the main doline gallery, but not collected.

Description. With the fossil fragment provided in parenthesis, the specimens measured as follows: maximum skull length $91.9 \mathrm{~mm}$, maximum upper maxilla length $51.2 \mathrm{~mm}(45.2 \mathrm{~mm})$, maximum nasal opening width $18.1 \mathrm{~mm}(17.1 \mathrm{~mm})$, and maximum maxillary width $14.3 \mathrm{~mm}(14.5 \mathrm{~mm})$. The femur measured in maximum length (GTL) $69.4 \mathrm{~mm}$, proximal maximum width (GPW) $18.9 \mathrm{~mm}$, distal maximum width (GDW) $17.6 \mathrm{~mm}$, and a maximum width of the diaphysis (shaft-GSW) $18.1 \mathrm{~mm}$. The 

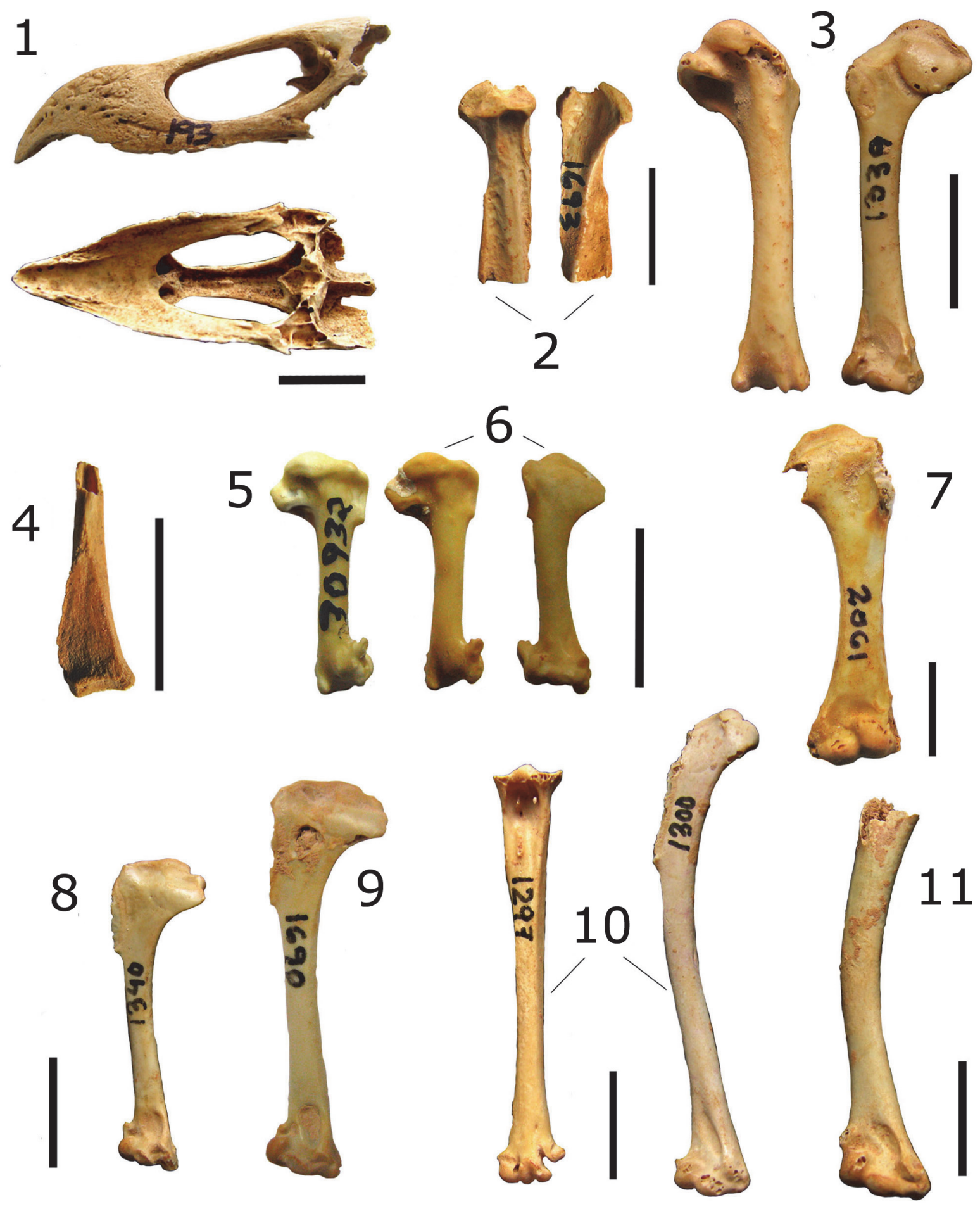

FIGURE 5. Bird fossil and subfossil remains from test pit D. 1, Cathartes aura maxilla in lateral and dorsal view. 2, proximal tibiotarsus of Colaptes cf. fernandinae. 3, the humerus of Psittacara eups. 4, distal coracoid of Progne cf. cryptoleuca or subis. 5, humerus of Tachycineta bicolor (FLMNH-UF 17685); 6, humerus of Tachycineta cf. bicolor. 7, humerus of Geotrygon cf. chrysia. 8, humerus of Sphyrapicus varius. 9, humerus of Melanerpes superciliaris. 10, tarsometatarsus (left) and humerus of Margarobyas lawrencii. 11, humerus of Saurothera merlini. The numbers on specimens are field numbers. Each scale bar represents $10 \mathrm{~mm}$. 
fossil premaxilla is not mineralized but showed slight evidence of corrosion and weathering.

Taxonomic remarks. Suárez (2001) mentioned the existence of two undescribed extinct vultures from Cuba. One of them seems referable to the genus Cathartes but is not $C$. aura (Suárez, 2001; Orihuela, 2019). However, the specimen reported here seems indistinguishable quantitatively or qualitatively from $C$. aura (Figure 5.1). Our specimen from layer $G$ lacks a direct date, but it was found between the dated contexts ranged between $1690 \pm 30$ and $1290 \pm 30$ rcyr BP and is thus preliminarily considered late Holocene/pre-Columbian in age. Therefore, this constitutes the first preColumbian record of $C$. aura in Cuba.

$$
\begin{gathered}
\text { Order PICIFORMES Meyer and Wolf, } 1810 \\
\text { Family PICIDAE Leach, 1820 } \\
\text { Genus COLAPTES Vigors, 1825 } \\
\text { Colaptes sp. cf. fernandinae (Vigors, 1827) or } \\
\text { auratus (Linnaeus, 1758) } \\
\text { Figure 5.2 }
\end{gathered}
$$

Material. A single, distal tibiotarsus fragment from layer G (level III) (MNHNCu uncatalogued; field number 1693) (Figure 5.2).

Description. This is a weathered specimen with evidence of digestion. It measures in greatest distal width (GDW) $5.01 \mathrm{~mm}$ and greatest shaft width (GSW) $2.2 \mathrm{~mm}$.

Taxonomic remarks. This specimen is slightly larger than Melanerpes superciliaris (uncatalogued from this deposit), M. radiolatus (UF 27075), GDW 4.90-4.91 mm, and GSW 1.93-1.95 mm, and Xiphidiopicus percusus (UF 36476: GDW $4.06 \mathrm{~mm}$ and GSW $1.6 \mathrm{~mm}$ ). About similar size or slightly smaller than Colaptes auratus (UF 45035: GDW $5.67 \mathrm{~mm}$ and GSW $1.96 \mathrm{~mm}$ ), which suggests a medium-sized woodpecker $(\sim 33-35 \mathrm{~cm}$; Short, 1965). In Cuba, the only two woodpeckers that fall within this size category are the endemic Fernandina's flicker Colaptes fernandinae $(\sim 34 \mathrm{~cm})$ and the flicker $C$. auratus $(\sim 33 \mathrm{~cm})$ (Garrido and Kirkconnell, 2000). Our tibiotarsus (no. 1693) resembles Colaptes more than Melanerpes in having marked and narrower intermuscular line and low (unflattering) fibular crest. The outer cnemial crest is more arched or circular in our specimen, as in Colaptes, and not more open as in Melanerpes. However, we did not compare it directly to C. fernandinae, and thus its identification remains tentative. An additional proximal tibiotarsus (no. 1794; not figured) from layer I (level IV) is similarly attributed to this taxon ( $\mathrm{O}$. Jiménez personal commun., 2015, 2018).
Order PSITTACIFORMES Wagler, 1832

Family PSITTACIDAE Illiger, 1811

Genus PSITTACARA (Wagler, 1832)

Psittacara eups (Wagler, 1832) sensu Remsen et al. (2013)

Figure 5.3

Material. A complete right humerus (field number 1339) from layer $\mathrm{G}$ (level III) (Figure 5.3).

Description. Well-preserved specimen, measuring in total length (TL) $28.2 \mathrm{~mm}$, GDW $5.8 \mathrm{~mm}$, greatest proximal width (GPW) $9.26 \mathrm{~mm}$, and GSW 2.69 $\mathrm{mm}$.

Taxonomic remarks. This specimen compares in size with Psittacara parakeets such as Psittacara nana from Jamaica (UF 25929): TL $29.8 \mathrm{~mm}$, GDW $6.01 \mathrm{~mm}$, DPW $10.1 \mathrm{~mm}$, and GSW $2.55 \mathrm{~mm}$. Morphologically is most similar to this genus in having a shallow bicipital furrow, scarcely grooved bicipital furrow and deltoid crest, round head, poorly developed external tuberosity proximally. Distally, shallow brachial depression, and etepicondylar prominence. It was qualitatively comparable to the endemic Cuban parakeet $P$. eups (Garrido and Kirkconnell, 2000). This specimen was associated with the species and is likely of the same age. This constitutes the first pre-Columbian record for the species.

Order PASSERIFORMES Linnaeus, 1758

Family HIRUNDINIDAE Rafinesque, 1815 Genus PROGNE Boie, 1826

Progne sp. cf. cryptoleuca (Baird, 1865) or P. subis

(Linnaeus, 1758)

Figure 5.4

Material. Incomplete, distal left coracoid, stained brown red (field number 1624), from layer $\mathrm{H}$ (level III) (Figure 4).

Description. This specimen may represent a juvenile because of its porosity and rounded sternal facet (Figure 5.4). Measurements: GDW $4.39 \mathrm{~mm}$ and GSW $1.75 \mathrm{~mm}$.

Taxonomic remarks. This coracoid represents a swallow larger than any other of the species present in Cuba. In morphology, it is like $P$. subis but slightly smaller. The purple martin ( $P$. subis) and the Cuban martin ( $P$. cryptoleuca) are common in Cuba. The first is a common transient between August and March, whereas the second is a common resident nearly year-round (Garrido and Kirkconnell, 2000, p. 168). Neither species has been previously reported from the paleontological or archaeological record of Cuba. 
Genus TACHYCINETA Cabanis, 1850

Tachycineta cf. bicolor (Vieillot, 1808)

Figure 5.6

Material. A complete left humerus (MNHNCu, uncatalogued) from layer $\mathrm{G}$ (level III).

Description. The specimen is slightly mineralized, small, and delicate. It measures in GTL $15.3 \mathrm{~mm}$, GDW $5.5 \mathrm{~mm}$, GSW $1.6 \mathrm{~mm}$, and GPW $6.6 \mathrm{~mm}$. (Figure 5.6).

Taxonomic remarks. This specimen is remarkably like the tree swallow $T$. bicolor, a common transient in Cuba (Garrido and Kirkconnell, 2000, p. 169). Our specimen agrees well in size and morphology to a male from Indian River, Florida, USA (UF 17685/30932): GTL 15.3-15.4 mm, GDW 4.91$5.22 \mathrm{~mm}$, GSW 1.62-1.64 mm, and GPW $6.44 \mathrm{~mm}$ (Figure 5.6). The ectepicondylar prominence is prominent and grooved at the tip, with a slight lateral extension (rounder, shorter, and attached in Hirundo rustica and hook-like in Progne subis). The internal condyle entepicondyle is less pronounced than the external condyle, but more than the intercondylar furrow, which is slightly flattened (not in $H$. rustica or very pronounced in $P$. subis). The bicipital furrow and deltoid crest are poorly developed off the main shaft. The capital groove is deeply excavated, unlike Hirundo, which has a double furrow (deep single furrow in Progne). Thus, we refer it tentatively here to $T$. bicolor. A direct comparison to the Bahamian tree swallow $T$. cyaneoviridis was not conducted. However, this taxon is a slightly larger rare winter transient in Cuba (Garrido and Kirkconnell, 2000). This represents the first paleontological, pre-Columbian record for Cuba.

Class MAMMALIA Linnaeus, 1758

Order RODENTIA Bowdich, 1821

Family CAPROMYIDAE Smith, 1842

Order MESOCAPROMYS Varona, 1970

Mesocapromys sp.

Material. This genus is represented by over 50 specimens, most of which are long bones, representing at least two species and 20 individuals. The two species are represented by Mesocapromys nanus (Allen, 1917) and Mesocapromys kraglievichi (Varona and Arredondo, 1979). This genus was present at all levels and in most beds, but more profusely in level III and IV (Table 4).

Description. Most remains showed taphonomic evidence of predation and digestion. Others were mineralized or adhered to a carbonate matrix. Most were juveniles with open or incomplete epiphysis and alveoli.
Taxonomic remarks. Although Silva Taboada et al. (2007) and M. Condis (2005) provided size groups for elements of the appendicular skeleton, attributing any of these long bones to a specific species is problematic due to the lack of complete skeletons as comparative material. Often, identification and assignment are satisfactory when complete adult hemimandibles are present in the assemblage, for which there are diagnostic $M$. nanus and $M$. kraglievichi. At present, the only diagnostic trait distinguishing them is the lateral extension of the condyle's ascending ramus process beyond the plane orientation of the angular process in $M$. nanus when the dentary is in occlusal view (i.e., viewed from above; Silva Taboada et al., 2007 p. 176). In M. kraglievichi, the ascending ramus follows the same plane as the angular process below. However, both species could be considered synonyms in the future (Osvaldo Jiménez and Lazaro W. Viñola, personal commun., 2017). Most of the undetermined material is assigned to Mesocapromys spp. indet. Table 3 represents juveniles, just as those of the extinct Geocapromys columbianus and the extant Capromys pilorides, which were well-represented in the assemblage (Tables 3-4).

\section{Order EULIPOTYPHLA Waddell et al., 1999 Family SOLENODONTIDAE Gill, 1872 Genus SOLENODON Brandt, 1833 Solenodon cubanus Peters, 1861}

Material. A left proximal ulna fragment from layer $\mathrm{E}$ (level II). A complete edentulous right mandible (uncatalogued) and complete left scapula (MNHNCu, field no. 2029) from a surface collection near the deposition cone, under the main sinkhole. The former specimen yielded a direct ${ }^{14} \mathrm{C}$ age of $650 \pm 15$ BP (UCIAMS 218808; Orihuela et al., 2020a).

Description. The surface specimens likely belong to the same individual, and appeared fresh (weathering level 0), with slight discoloration. The ulna was slightly mineralized and showed evidence of cracking (weathering level 1) and represents another individual from the sinkhole deposit above.

Taxonomic remarks. These specimens are indistinguishable from Solenodon cubanus. The radius was associated with the bat Phyllops vetus that yielded an age of 1960 rcyr BP, thus indicating a pre-Columbian, late Holocene age for that specimen, whereas those from the surface may be several hundred years old, as is supported by the ${ }^{14} \mathrm{C}$ age estimate of the left scapula (no. 2029). 

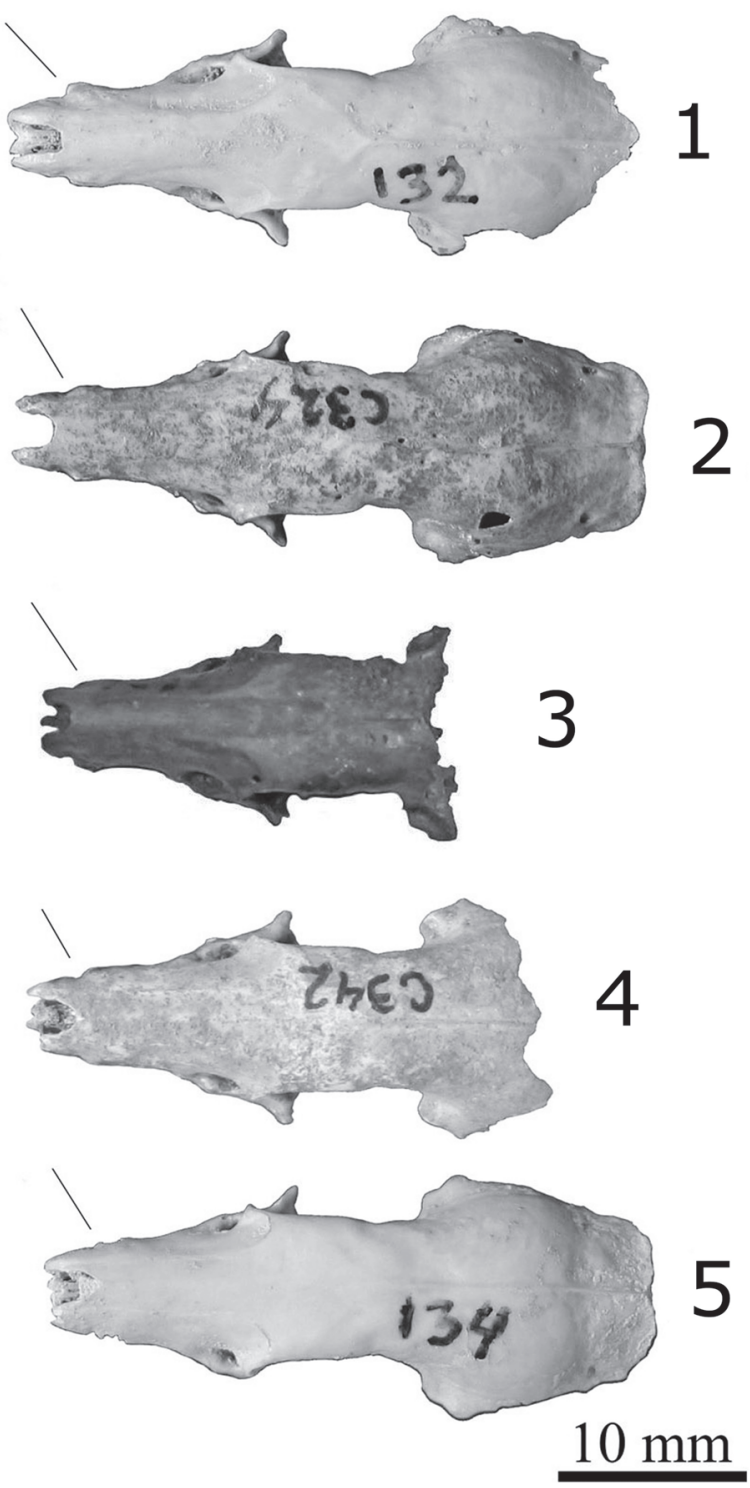

FIGURE 6. Nesophontes skulls on dorsal view. 1-3, Nesophontes cf. longirostris; 3 is the holotype (AMNH 17626). 4-5, Nesophontes major. Small lines indicate discrete characters discussed in the text. Note the more elongated rostrum and wider gap between upper premolars in $N$. longirostris and the crowding in $N$. major.

Family NESOPHONTIDAE Anthony, 1916

Genus NESOPHONTES Anthony, 1916

Nesophontes sp. cf. longirostris sensu Anthony, 1919

Figures 7.1-7.3, 8.1-8.3, 9.1-9.2

Material. Three specimens may represent this taxon: a near-complete skull, lacking the occipital and petrosals (MNHNCu field no. 132), and two possible hemimandibles (MNHNCu, field no. 121
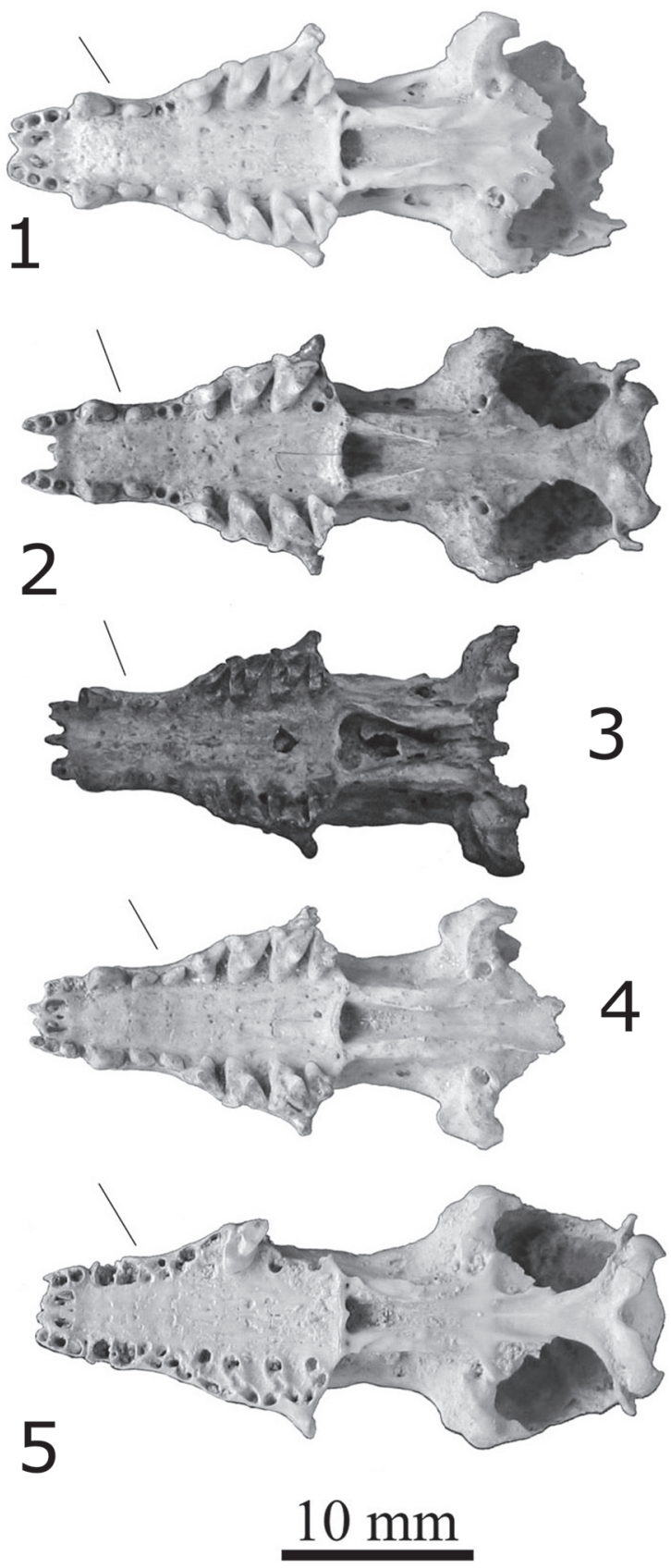

FIGURE 7. Nesophontes skulls on ventral view. 1-3, Nesophontes cf. longirostris, $\mathbf{3}$ is the holotype (AMNH 17626). 4-5, Nesophontes major. Small lines indicate discrete characters discussed in the text.

and 1428). The first skull and mandible are from layer E (level II), and the last (no. 1428) was from layer $\mathrm{H}$ (lower level III).

Description. Large species of Nesophontes, like N. major (Figures 6-9), but with a tubular and more elongated rostrum, wider diastemata between upper and lower canine and first two premolars. Skull 132 and dentary 121 were slightly mineral- 

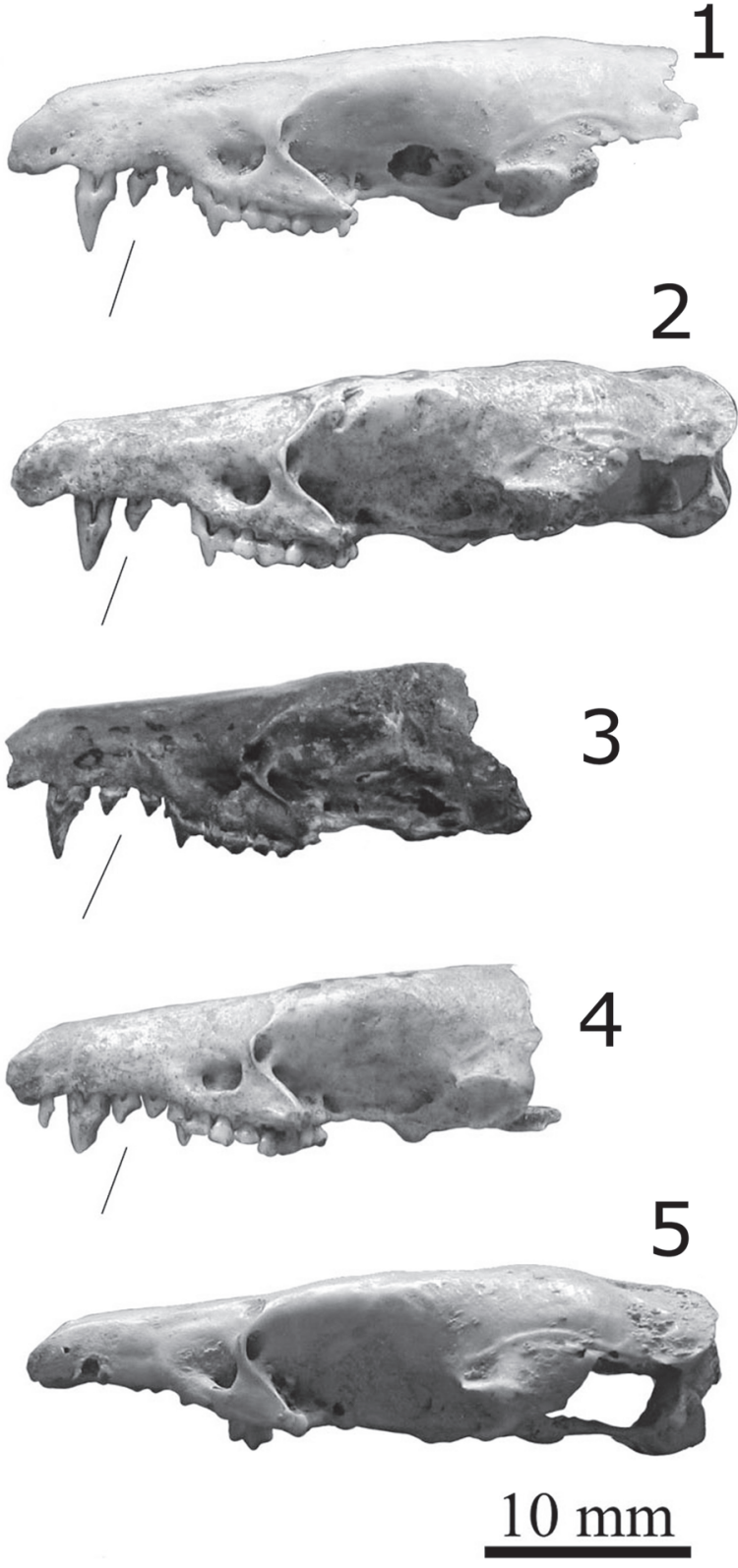

FIGURE 8. Nesophontes skulls on lateral view. 1-3, Nesophontes of. longirostris, $\mathbf{3}$ is the holotype (AMNH 17626). 4-5, Nesophontes major. Small lines indicate discrete characters discussed in the text.

ized, and dentary 1428 partially mineralized. Measurements are provided in Table 5.

The skull of $N$. longirostris is most like that of Nesophontes major (Figures 6-9) but differs in being slightly larger, with a slenderer and more elongated rostrum, more parallel postorbital, with a wide diastema between the upper canine and the first two maxillary premolars (Pm1-Pm3). The is also a wider separation between the last incisor and the canine. In N. major, the rostrum is broader,
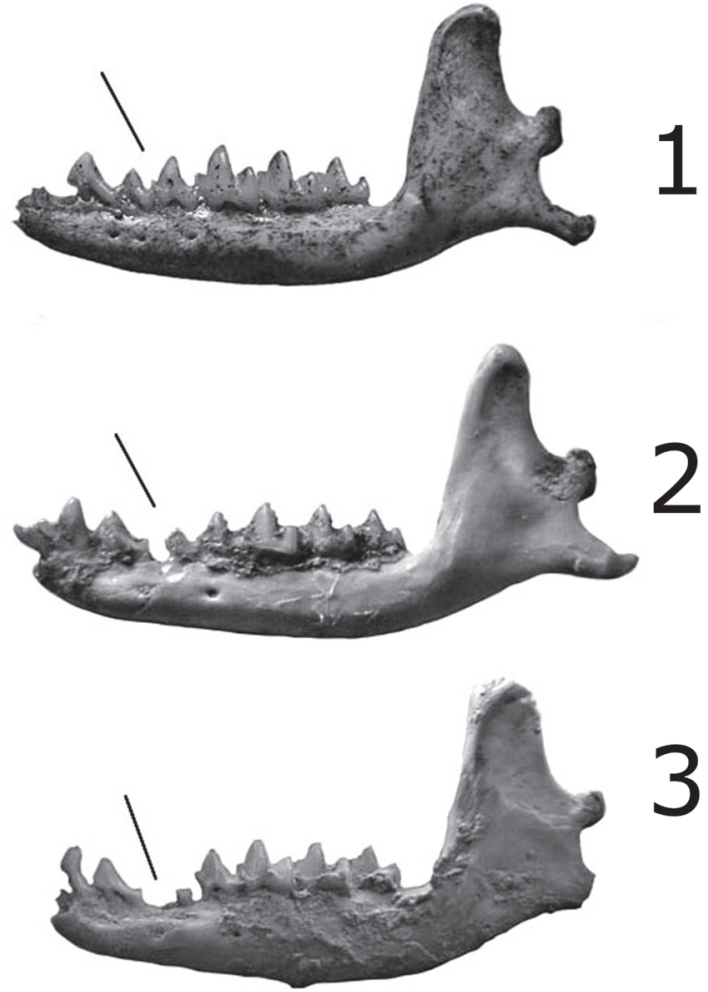

\section{$10 \mathrm{~mm}$}

FIGURE 9. Nesophontes left hemimandibles 1-2, Nesophontes cf. longirostris. 3, Nesophontes major (image inverted).

more U-shaped, and wider at the level of the canines. The inclination angle of the nasal is more pronounced in $N$. longirostris than $N$. major (Figures 6-9).

Nesophontes longirostris shows an incipient tapering at the level of the first and second maxillary premolars, not present in N. major (including juvenile individuals). The orientation and size of the premolars in $N$. micrus are nearly parallel to the axis of the toothrow and of nearly equal size (see Figure 8.1-3). In N. major, the premolars are always crowded, oriented obliquely from the toothrow, and the first premolar is always larger than the second (Figure 8.4-5). In N. longirostris, the orientation of the premolars is slightly oblique, despite their wide separation. In $N$. longirostris the Paracone is reduced in the third upper molar (M3) but is smaller and slimmer than M1 and M2. M1 is slightly smaller than $\mathrm{M} 2$ and very subtriangular in shape. In N. major the M3 is more robust and wider 
TABLE 5. Nesophontes craniomandibular measurements, including the specimens tentatively identified here as $N$. cf. longirostris. All specimens are from Cueva de los Nesofontes, except two N. longirostris (one is the AMNH holotype, and the other a specimen from Cueva del Gato Jíbaro referenced in the text). Maximum Dental Length is equivalent to the upper and lower toothrow length, i.e., the length measured from most distal incisor to M3 (m3).

\begin{tabular}{|c|c|c|c|c|}
\hline Species & Measurement & $\mathbf{N}$ & Mean \pm SD & Range \\
\hline \multirow[t]{8}{*}{ Nesophontes micrus } & Max. Dental length & 56 & $12.89 \pm 0.3$ & $12.2-13.56$ \\
\hline & C-M3 length & 67 & $10.55 \pm 0.3$ & $10.01-11.33$ \\
\hline & Max. Palatal length & 56 & $13.09 \pm 0.4$ & $12.2-13.99$ \\
\hline & Max. Canine breath & 68 & $3.61 \pm 0.2$ & $3.23-4.66$ \\
\hline & Max. Canine-Pm3 length & 70 & $2.35 \pm 0.2$ & $1.7-2.91$ \\
\hline & Max. dentary length & 243 & $18.03 \pm 0.6$ & $16.0-19.3$ \\
\hline & Max. dentary dental length & 257 & $11.48 \pm 0.3$ & $10.18-12.56$ \\
\hline & Max. c-pm3 length & 6 & $3.07 \pm 1.7$ & $2.66-3.49$ \\
\hline \multirow[t]{8}{*}{ N. major } & Max. Dental length & 43 & $14.53 \pm 0.6$ & $12.63-15.46$ \\
\hline & C-M3 length & 56 & $11.75 \pm 0.5$ & $10.02-12.65$ \\
\hline & Max. Palatal length & 42 & $14.7 \pm 0.5$ & $13.56-15.53$ \\
\hline & Max. Canine breath & 62 & $4.86 \pm 0.04$ & $4.23-5.44$ \\
\hline & Max. Canine-Pm3 length & 65 & $2.30 \pm 0.04$ & $1.59-2.98$ \\
\hline & Max. dentary length & 147 & $20.77 \pm 0.7$ & $18.09-22.6$ \\
\hline & Max. dentary dental length & 160 & $13.0 \pm 0.5$ & $11.44-14.4$ \\
\hline & Max. c-pm3 length & 9 & $2.92 \pm 2.1$ & $2.31-3.45$ \\
\hline \multirow[t]{8}{*}{ N. longirostris } & Max. Dental length & 4 & $14.87 \pm 1.2$ & $13.58-15.83$ \\
\hline & C-M3 length & 4 & $12.35 \pm 0.09$ & $11.80-12.4$ \\
\hline & Max. Palatal length & 4 & $15.43 \pm 0.6$ & $14.0-15.9$ \\
\hline & Max. Canine breath & 4 & $4.85 \pm 0.4$ & $4.4-5.26$ \\
\hline & Max. Canine-Pm3 length & 4 & $3.33 \pm 0.1$ & $3.20-3.45$ \\
\hline & Max. dentary length & 2 & $22.34 \pm 0.3$ & $22.08-22.60$ \\
\hline & Max. dentary dental length & 2 & $13.72 \pm 0.2$ & $13.54-13.90$ \\
\hline & Max. c-pm3 length & 2 & $4.0 \pm 0.4$ & $3.58-4.42$ \\
\hline
\end{tabular}

(more quadrate), with a slightly higher Paracone, and the M1 is stubbier than the M2, with a less pronounced Metastyle (Figures 6-9).

In this sense, $N$. longirostris seems more akin to $N$. major than to $N$. micrus. Quantitatively, the two species are also most similar in most cranial linear measurements (Table 5). Nesophontes Iongirostris is slightly larger in skull, palatal, and dental length, likely as a function of the wider spacing between the premolars.

The dentary of Nesophontes major (both supposed males and females) are larger than micrus in several linear dimensions: total length of the dentary, the maximum height of coronoid process, and the maximum height of the mandibular ramus under m1-m2 (Table 5, Figure 9). In general, the dentary and lower dentition of $N$. major is more robust and marked than $N$. micrus. The dentary of $N$. major has a thicker ramus, with a more pro- nounced curve at the masseteric/digastric region (thinner, and much less curved in N. micrus; the muscle scar is less pronounced). The shape of the coronoid process is wider, broader, with more pronounced masseteric fossa on the lateral face, and deeper temporalis/pterygoid fossae on the medial face (subtriangular, thinner, less marked or shallow, and more restricted in $N$. micrus). The canine of $N$. major is an un-grooved premolaliform, with a small cingulum and more triangular cusp, and smaller base (wider base and wider triangularwider shear surface outline in $N$. micrus). In the molars, the angle between the paraconid and metaconid, as seen on the lateral aspect, is more closed, with a wider commissure (more open and lower in N. micrus, with a reduction in cingulum development). The scar of the mandibular symphysis in N. major is more pronounced and longer than in $N$. micrus. In this sense, the supposed mandible 
of $N$. longirostris is nearly identical to $N$. major (Figure 9.1), but with the diastemata present between pm1 and pm2 (Figure 9.2-3). Based on these qualitative and quantitative data, N. longirostris is tentatively revalidated here. Further detailed data is out of the scope of this paper and will be further discussed elsewhere.

Taxonomic remarks. H.E. Anthony described this species based on an incomplete skull (AMNH 17626; Figure 6.3, 7.3, 8.3, 9.3) from a cave deposit in Daiquirí, southeastern Cuba. He distinguished it from $N$. micrus by its longer and slenderer rostrum, plus a "distinct diastemata between the canine and the first premolars" (Anthony, 1919, p. 634). Anthony also predicted that such diastema would be found in the dentary. This diastema resulted in a larger measurement of $3.2 \mathrm{~mm}$ taken between the posterior border of the maxillary canine and the anterior border of the premolar, in comparison to other specimens he studied (Anthony, 1919). Since Morgan (1977) and subsequent revisors considered $N$. longirostris invalid and a synonym of either $N$. micrus or $N$. major (Condis et al., 2005; Silva Taboada et al., 2007; Rzebik-Kowalska and Woloszyn, 2012). Despite these evaluations and considering the intra and interspecific variation of the genus (JO unpublished data; Buckley et al., 2020), the characters displayed by these specimens seem to suggest otherwise.

Our specimens, both skulls and dentaries, have the supposed diagnostic diastemata, elongated rostrum, and measurements that exceed the observed variation in both $N$. micrus and $N$. major studied from several locations in Cuba ( $>720$ hemimandibles and $>150$ skulls; plus over 1030 specimens from this assemblage alone), in addition to Anthony's Daiquirí series at the AMNH. Moreover, adding the discovery of another complete skull specimen (MNHNCu, field no. 324; Figures 6.2, 7.2 and 8.2) with similar morphology and measurements from Cueva del Gato Jíbaro, $\sim 18 \mathrm{~km}$ east from the assemblage described here. This last specimen is associated with the archaeological kitchen midden dated to $860 \pm 30$ years before the present (Orihuela et al., 2020a).

Order CHIROPTERA Blumenbach, 1779

Family PHYLLOSTOMIDAE Gray, 1825

Genus ARTIBEUS Leach, 1821

Artibeus anthonyi Woloszyn and Silva Taboada, 1977

Figure 10.1

Material. Eight specimens (MNHNCu, uncatalogued), representing at least three individuals in the assemblage belong to this species. These were a rostrum, three hemimandibles (no. 11, 12, and 1663), and four humeri encountered within layer H (lower level III) and layer I (level IV) (Figure 10.1).

Description. These specimens were mineralized, with a few including calcareous encrustations. One of them, a slightly mineralized and robust right hemimandible (no. 1663) found at the bottom of layer $\mathrm{H}$ (lowermost level III) yielded a direct radiocarbon date of $1290 \pm 30$ rcyr BP (Figure 10.1), providing the first direct LAD for this taxon in Cuba.

Taxonomic remarks. The humeri measured between 36.0 and $37.7 \mathrm{~mm}$, and the mandibles had a total length greater than $18.4 \mathrm{~mm}$ and less than $22.0 \mathrm{~mm}$. These specimens were identified from Artibeus jamaicensis, and the Cuban subspecies parvipes, based on size and criteria published by Anthony (1919), Woloszyn, and Silva Taboada (1977, 1979), Balseiro et al. (2009), and Orihuela (2010). Artibeus anthonyi has been reported from another deposit in Cueva de los Nesofontes (Orihuela, 2010; Orihuela et al., 2020a, 2020b). The species seems to have been widespread in the archipelago. So far, $A$. anthonyi has been documented from 11 localities (Borroto-Páez and Mancina, 2017). Including this record and another from a paleontological layer at Cueva del Gato Jíbaro adds to 13 localities. This last specimen yielded a middle Holocene ${ }^{14} \mathrm{C}$ direct date estimate (Orihuela et al., 2020a, 2020b).

\section{Artibeus jamaicensis Leach, 1821}

Material. The Jamaican fruit bat was represented by 173 skulls, 254 mandibles, and 45 humeri. Radii and other parts of the appendicular skeleton were not fully counted, but more than 22 specimens, including scapulae and femora, represented this species. NISP of 495 and an MNI of at least 165 individuals (Table 3 ).

Description. After Nesophontes micrus and $N$. major, this taxon was the third most common taxon of the assemblage. Remains of this species displayed multiple taphonomic marks of deposition, mineralization, decomposition, predation, and digestion.

Taxonomic remarks. Most of these specimens are indistinguishable morphologically and metrically from the Cuban endemic subspecies $A$. jamaicensis parvipes. However, eight crania, eight hemimandibles, and four humeri (NISP of 21), indicated in Table 3 as $A$. jamaicensis, were larger than the maxima of the fossil and neontological range provided by Silva Taboada $(1974,1979)$ and 

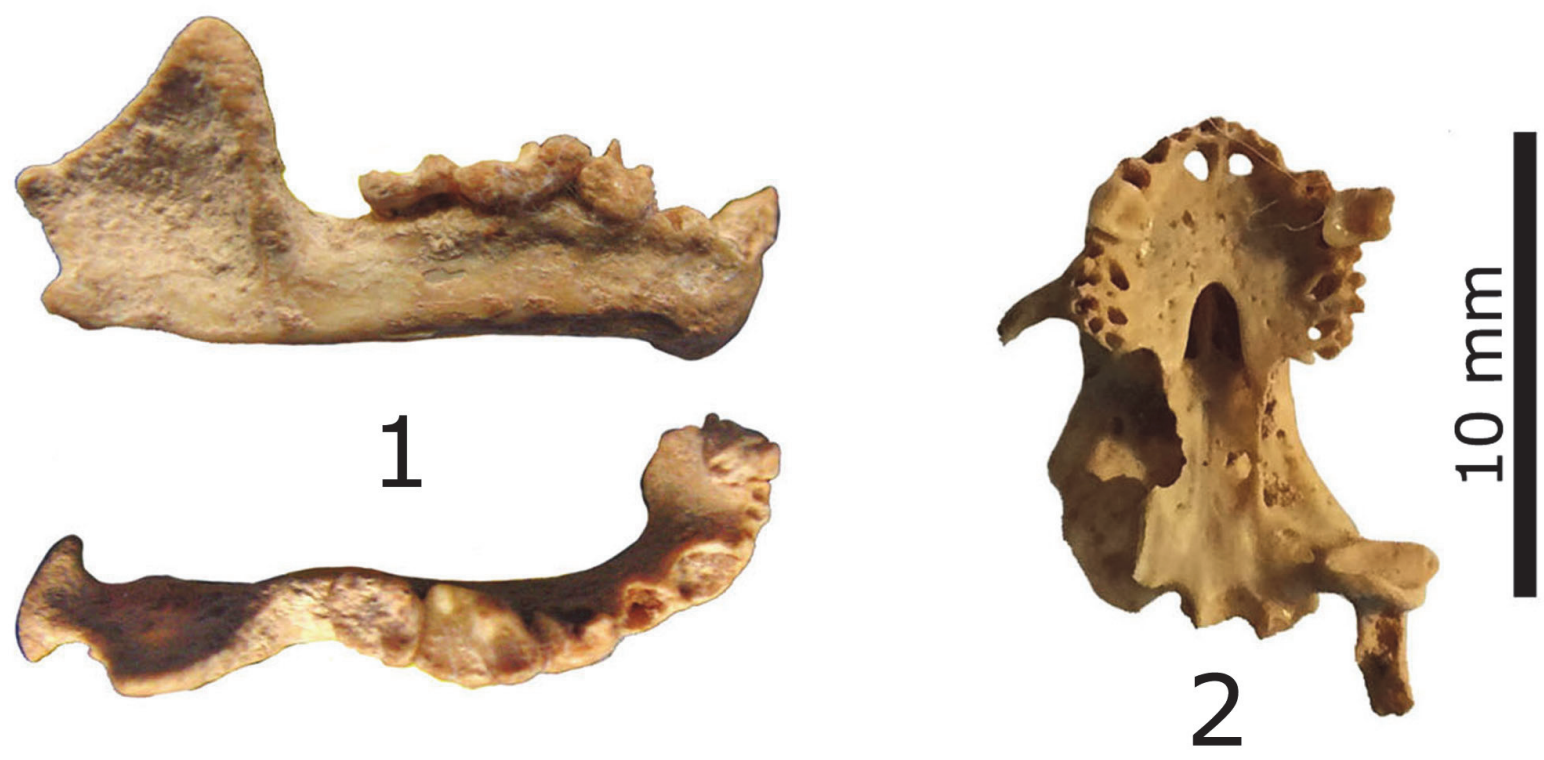

\section{$10 \mathrm{~mm}$}
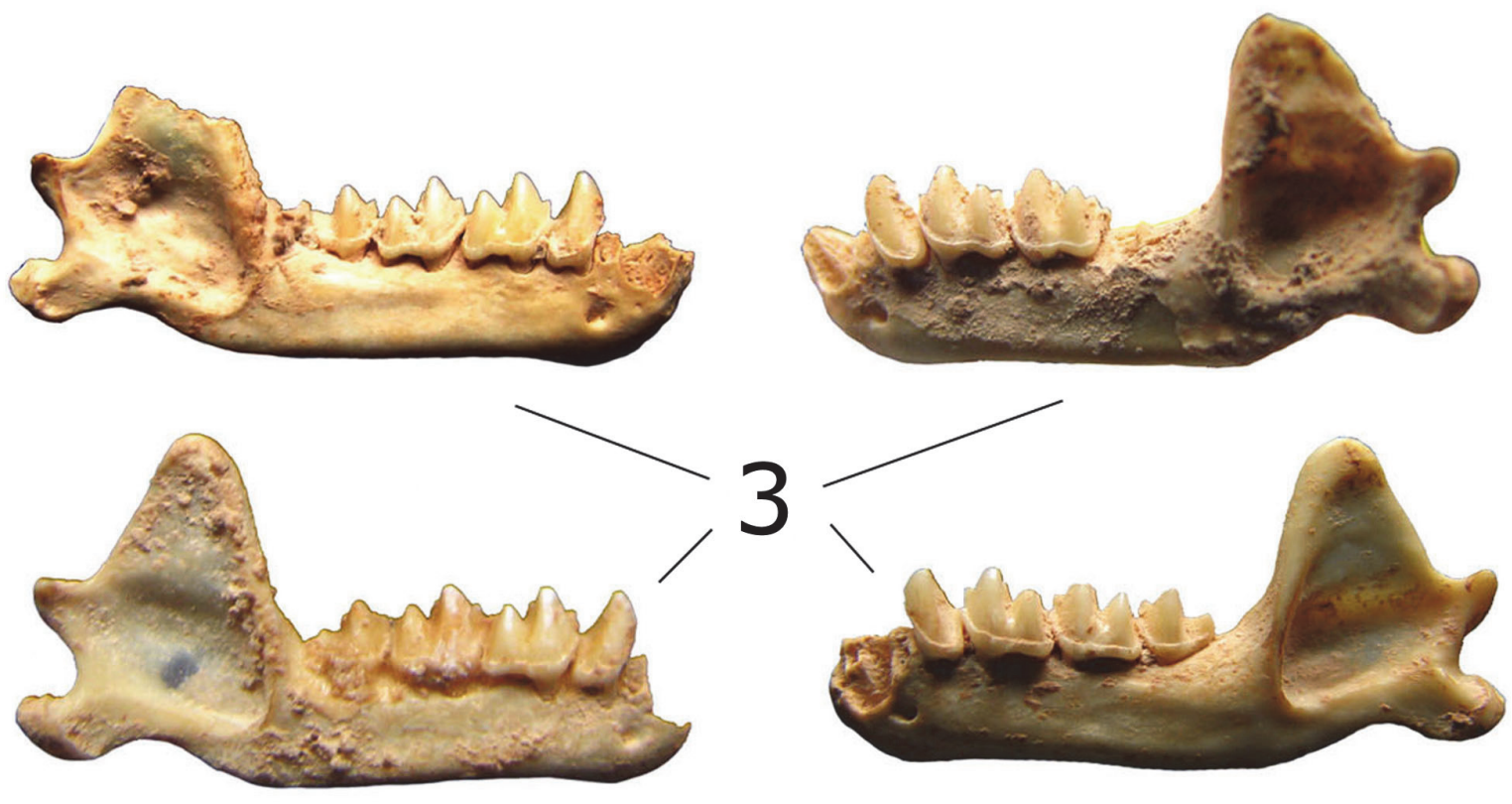

FIGURE 10. Bats. 1, left hemimandible of Artibeus anthonyi (no, 1663, lower Level III). 2, ventral view of Phyllops vetus incomplete skull (no. 37, Level II). Both specimens were radiocarbon-dated (14C). 3, four hemimandibles of Antrozous koopmani (no. 20, 75, 1429, 1430 from Levels II and IV, also ${ }^{14} \mathrm{C}$ dated). These specimens were also dated, helping corroborate the chronology discussed. The scale bar equals $10 \mathrm{~mm}$.

Balseiro et al. (2009). These specimens slightly exceeded the upper range of $A$. jamaicensis parvipes in palatal length $(>13.5 \mathrm{~mm})$, anteorbital width $(>8.5 \mathrm{~mm})$, and postorbital breath $(>7.2 \mathrm{~mm}$ ) (Silva Taboada, 1979). In this last measurement, it also exceeded values reported for $A$. anthonyi (>7.4 $\mathrm{mm}$; Woloszyn and Silva Taboada, 1977; Balseiro et al., 2009) and Artibeus lituratus ( $>6.7 \mathrm{~mm}$ in Woloszyn and Silva Taboada, 1977). This variation may be a form of temporal or chronoclinal variation 
but will be further explored elsewhere. Since these specimens are qualitatively inseparable from $A$. jamaicensis, they are included within this taxon. These specimens occurred exclusively in layers $\mathrm{H}$ and I (levels III and IV) where they were directly associated with $A$. jamaicensis, $A$. anthonyi, and Phyllops vetus.

\section{Genus PHYLLOPS Peters, 1865 \\ Phyllops vetus Anthony, 1917}

Material. Taxon represented by eight fragmentary skulls, including rostra, nine dentaries, and three humeri, representing at least eight individuals (MNHNCu, uncatalogued).

Description. Most remains were fragile and slightly mineralized. A skull (no. 37) found in layer E (level II; Figure 10.2) yielded a radiocarbon age of $1960 \pm 30$ rcyr BP, constituting the first direct LAD for this species.

Remarks. This taxon appeared in association with the Cuban fig-eating bat $P$. falcatus only in layer $\mathrm{G}$ (level III), which yielded radiocarbon ages between $\sim 1960$ and 1290 rcyr BP; Table 4. P. vetus occurred at all levels except level I (layers A-D, in Figure 4). These age estimates are further supported by radiocarbon dates now available for this level (Orihuela et al., 2020a).

Family VESPERTILIONIDAE Gray, 1821

Genus ANTROZOUS H. Allen, 1862

Antrozous koopmani Orr and Silva Taboada, 1960 Figure 10.3

Material. This taxon was represented by a partial skull (MNHNCu uncatalogued), a fragmentary braincase (MNHNCu uncatalogued), and five dentaries (MNHNCu uncatalogued, field no. 19, 20, 75, 1429,1430 ), occurring in all layers between level II and IV (Figure 10.3). Three of these have provided direct radiocarbon dates from beds $F, G$, and $I$, which agree with the overall late Holocene age estimates for these intervals (Orihuela et al., 2020a, 2020b).

Description. The specimens were well-preserved, often showing evidence of predation and digestion. They did not deviate quantitatively or qualitatively from other reported specimens (Orr and Silva Taboada, 1960; Silva Taboada, 1976; 1979; García and Mancina, 2011). Viera (2004) reported other specimens from surface collections in the same cave (see Orihuela et al., 2020b).

Taxonomic remarks. The Cuban pallid bat needs a detailed revision. Although it is often considered a subspecies of the continental species Antrozous pallidus from western North America (Simmons, 2005), we consider that the differences in morphol- ogy and size warrant its retention as a distinct endemic species until further analyses are conducted (following Silva Taboada, 1976; Silva Taboada and Vela, 2009; García and Mancina, 2011). This species was undetected in Cuba until the mid-twentieth century. The first and only complete specimens preserved were two females collected by Charles T. Ramsden in 1920-1921, near Bayate, Guantanamo, eastern Cuba, but misidentified as "Macrotus" (Silva Taboada, 1976). A. koopmani has been found in several "fresh" owl pellets across the island, which suggest a former wide range in the island, but has not been confirmed captured or observed live since 1956 (Orr and Silva Taboada, 1960; Silva Taboada, 1979; Borroto-Páez and Mancina, 2017), although a questionable report exists (Mancina, 2012). Moreover, it has been shown that pellet material that seems "fresh" can be several hundreds of years old (MacPhee et al., 1999), as also supported by the Solenodon material discussed. This species is extremely rare in collections, currently extremely vulnerable or already extinct.

\section{Other Organisms}

Pollen, plant seeds, phytoliths, and starch grains were detected at all intervals of the deposit but remain unstudied (Figure 11). Gastropods and crabs were very common throughout the deposit. At least nine species of land snails and a land crab, Gecarcinus ruricola, were present and abundant in the assemblage. The land snails included the following preliminary taxa: Alcadia sp. cf. hispida, Farcimen cf. procer, Chondropoma cf. vespertinum, Oleacina subulata, Opisthosiphon sp., Nescoptis sp., Liguus fasciatus, and Zachrysia auricoma. The last two and Chondropoma sp., being the most abundant. Unidentified plant fragments such as leaves, bark, microcharcoal, and seeds were also present (Figure 11).

Insect chitin was present in the matrix of the upper levels (I and II). Within the lowest levels, microscopic fragments of insect exoskeletons and fly pupae were rare but well preserved when present (Figure 11.5). One of the pupae specimens was identified as a phorid fly pupa (Figure 11.5). Remains of larvae were observed directly on the bones of several specimens at the level I and III.

Amphibians were represented by at least two genera, Eleutherodactylus, and Peltophryne spp., but otherwise difficult to assign to species. The Cuban tree frog Osteopilus septentrionalis is likely also present. The reptiles were identified as lizards of the Anolis group: the smaller Anolis sagrei, the 

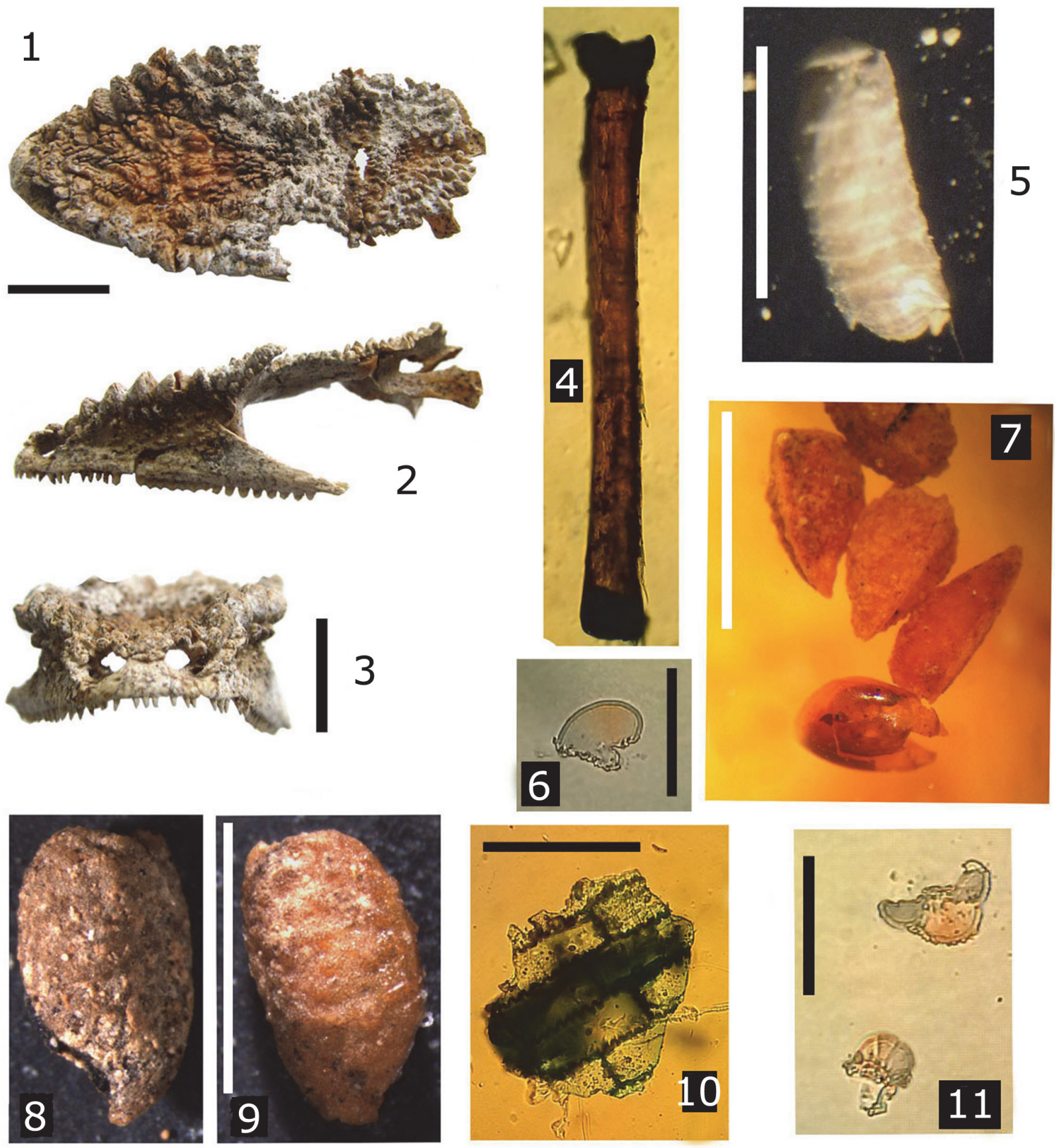

FIGURE 11. Plant, invertebrate, and reptile remains. 1-3, Anolis cf. chamaleolis (no. 606), scale bar $10 \mathrm{~mm}$ (Level I). 4, unidentified insect extremity $\sim 1 \mathrm{~mm}$ (Level IV). 5, photid fly pupa, scale $10 \mathrm{~mm}$ (Level IV). 6, fungus spore (?), scale $\sim 50 \mu \mathrm{m}$. 7, plant seeds, scale $5 \mathrm{~mm}$ (All from level II and III). 8-9, seeds, scale $5 \mathrm{~mm}$. 10, leaf fragment, scale $\sim 50 \mu \mathrm{m}$ (Level II). 11, plant spores, likely a conifer, Pinus? (Level IV), scale $\sim 50 \mu \mathrm{m}$.

larger Anolis equestris, a similar large Anolis sp., and $A$. cf. chamaeolonides (fide Nicholson et al., 2012; Rodríguez Schettino et al., 2013), this last on Figure 11.1-3.

\section{Taphonomic Observations}

Mineralization, coloration, and evidence of predation and digestion were the most common taphonomic evidence (Figure 12). Weathering was another important factor acting on the preservation 

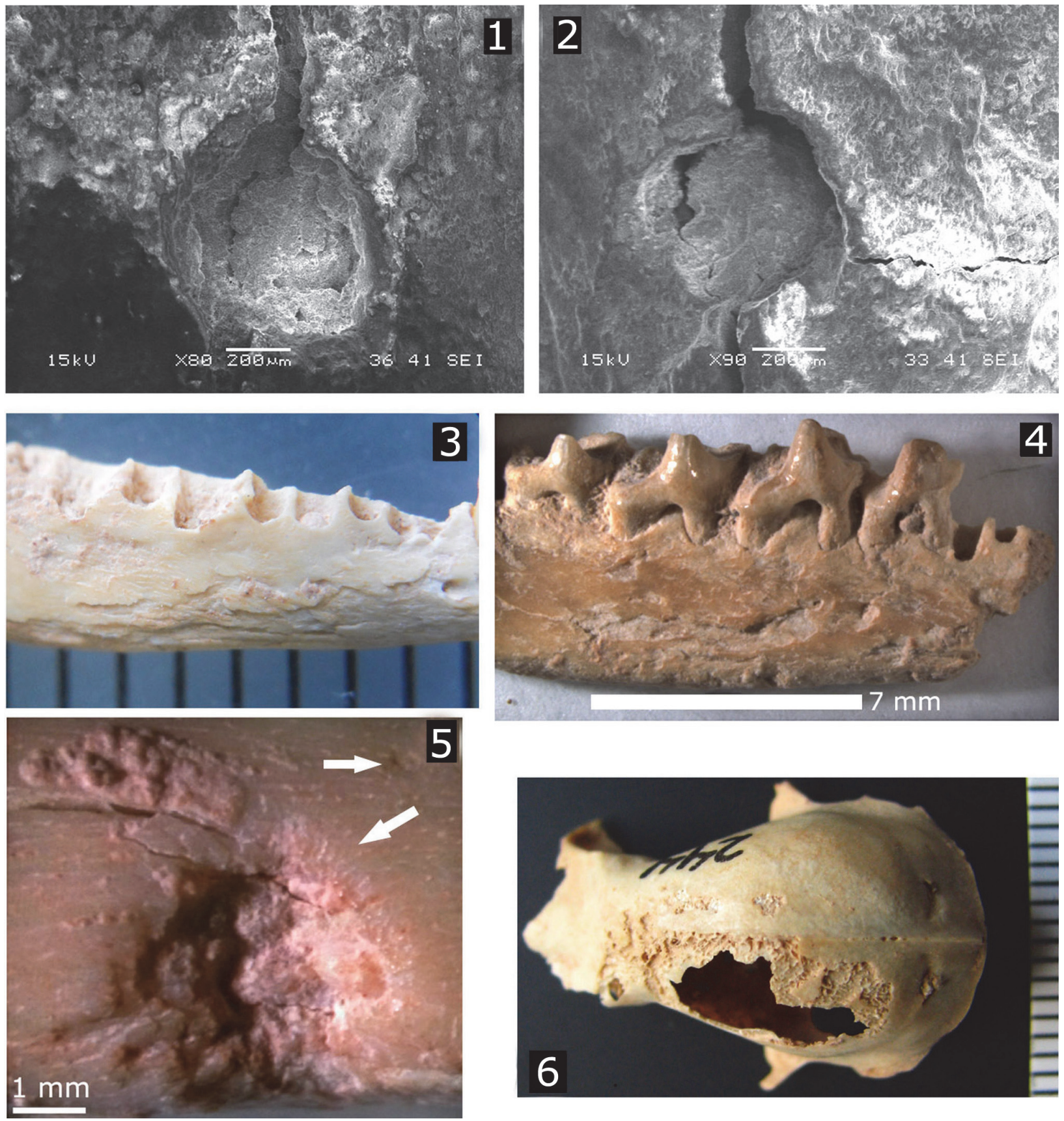

FIGURE 12. Taphonomic evidence. 1-2, SEM microphotographs of Nesophontes sp. tooth marks on small capromyid long bones. Note the well-rounded edges, microfractures radiating from the cortex. 3-4, Stage 3 weathering on an $N$. major left hemimandible (left) and stage IV on another (right). 5, Microscopic striae and notching associated with insect scavenging on the bone. The main depression is likely a tooth mark made on the bone while still fresh (note the gradual peeling features). 6, An A. jamaicensis adult skull with possible evidence of raptor predation and digestion (corrosion).

of the specimens. Evidence of predation in form of scratches, claw or beak marks, indentations, fractured braincases, and digestion corrosion, were much more frequent in the upper levels (I and II), whereas most mineralization and maximum weathering levels (>level 2) were more evident in lower levels. Weathering levels or stages varied generally between 0 and 2 , only rarely did specimens show stages higher than or equal to 3 (Figure 12). Scavenging evidence in the form of gnawing and tooth marks by rodents and Nesophontes (Figure 
12.1-2) has been documented in detail from this assemblage (Orihuela et al., 2016).

Decomposition-related insect activity such as boreholes, etchings, and fungal activity was less common (Figure 12.5), but likely related to the exposure of the pellets before and during the formation of the deposit. In several cases, the soft clay of the deposit invaded the empty braincase cavities of several Nesophontes specimens, creating natural endocasts (Orihuela, 2014).

Skulls and mandibles were the most common of all skeletal elements, with 476 and 1359 specimens, respectively; they contributed $14.2 \%$ and $59.1 \%$ to the osseous remains in the assemblage (Pit D). Thus, cranial elements, especially mandibles, dominated the assemblage at $79.8 \%$. Humeri (133 specimens) represented $4 \%$, and other elements of the appendicular skeleton (398 specimens) likely constituted a total of $17.2 \%$. It is important to note, however, that many radii and femora were fragmented and unidentifiable to species level, and thus, not counted.

\section{Pathologic Observations}

Evidence of pathologies was present in less than $1 \%$ of the assemblage. These were evident in the bats Artibeus jamaicensis, capromyid rodents, and Nesophontes in the form of bone lesions, healed fractures, general bone deformations, and dental-alveolar lesions. Three specimens of Nesophontes major were of special note: A left adult dentary showed a markedly open premolar root with indications of an alveolar infection. Two other hemimandibles showed, as supported by radiography (not illustrated here), healed fractures or deformed coronoid processes. Mineralization, insect activity, and digestion often caused corrosion on the bones that could be mistaken for fungal or pathologic conditions (e.g., Figure 12.5-6).

\section{DISCUSSION}

\section{Source of the Fossils: Sedimentology and Interpretation of Deposit Formation}

The vertebrate fossils that compose this assemblage presumably mostly originated from raptor-derived primary pellet deposits located above the main sinkhole that was slowly in-washed (transported) into the cone of deposition under the sinkhole. Based on the faunal composition of the upper layer and surface samples collected around the deposit, we can infer that other organisms were included in the assemblage also from natural death, such as the crustaceans, gastropods, rep- tiles, and several birds and bats. Among the samples collected from isolated non-pellet deposits included Canis, Tyto, and Cathartes aforementioned, plus an articulated skull and mandible of $N$. micrus found on a nearby wall. All these suggest other sources for fauna in the deposit.

With the organic remains came sediments from the upper scarp levels of Palenque Hill. Based on the SEM-EDS data, these soils were positively correlated $\left(R^{2}=0.8353 ; y=0.4526 x+1.9158\right)$ in $\mathrm{Si}, \mathrm{Fe}$ and $\mathrm{Al}$ weight percent composition with ferralitic clay soils of the Mayabeque-Matanzas lowlands (Formell and Buguelskiy, 1974), and with the ferralitic-ferromagnesic red soils of the upper scarp of Palenque Hill (asterisks in Figure 1.2). The changes in coloration are redoximorphic features, indicating depletion of oxidizing/reducing Fe-Mn conditions in the exposed and cave deposits. This supports the inference that both the sediments and fossils are allochthonous. Thus, the red cave soils are being transported from the above scarp into the cavities. Mineralization of fossils within the deposit suggests mild diagenesis through infiltrating water. However, the isotope values yielded by the tested samples indicated little or no major diagenesis other than slight mineralization.

Deposition seems to have been slow as is suggested by the marked stratigraphic architecture and the slow sedimentation rates calculated for several of the intervals. Layer or bed architecture was variable, several layers were separated by discernable disconformities that mark different erosional/depositional events and changes in sedimentation regimes (Figures 3-4). The beds were generally prograding, with the lowest layers representing lower energy (horizontal) depositions, whereas the upper-level layers were more amalgamated and inclined, suggestive of slightly higher energy flooding events resulting in more pronounced rill erosion. Several beds showed evidence of slump erosion and truncation likely caused by rill erosion (Figures 3-4). The weathering levels observed in osseous remains rarely surpassed stage 2, which suggests that the pellets and their content were exposed for only 2 to 4 years before final deposition and diagenesis, where they decomposed exposed to the air, thus attracting insects. This is likely to have occurred in the primary pellet deposit in the upper cave levels, and much before transportation into the cone deposit below.

One of these events (layer $F$ up to $C$ ) suggested a stratigraphic inversion mixture with a slightly faster sedimentation rate of $>1.3 \mathrm{~mm} / \mathrm{yr}^{-1}$. 
Together, layers F-C may constitute a flooding event in which older fossils were transported and deposited over younger deposits, as suggested by the ${ }^{14} \mathrm{C}$ AMS date for layer F, E, and D. Bioturbation also could have been a major source of reworking and stratigraphic inversion (Bosch and White, 2007; Patzkowsky and Holland, 2012). Although most exotic taxa occurred in the upper intervals, the anomalous presence of Rattus spp., Mus musculus, and Passer domesticus within the lower levels and the older ${ }^{14} \mathrm{C}$ date in level II support either mixing of diachronous fauna or a stratigraphic inversion at level II (Table 4; dated Antrozous and Boromys in Orihuela et al., 2020a). Land crabs, rodents, and island-shrews are known to excavate and burrow in the sediment and for scavenging (Andrews, 1990), which can result in the mixing of diachronous remains. However, the bioturbation index was low at most intervals, between 0 and 1 (i.e., 1-4\% overall bioturbation), except for interval II, which had a bioturbation index of $2(>15 \%)$.

Furthermore, the native rodent and Nesophontes tooth-marks reported in the assemblage (Orihuela et al., 2016), and the occurrence of a fly pupa and traces of insect activity on several of the bone remains (Figures 11-12) suggest that pellets laid exposed long enough to attract these scavengers before final deposition in the cone deposit. Overall, this supports the mixing of fauna in the upper primary deposits, causing some of the events and specimens to reach the deposition cone already mixed, or being further mixed there.

The large accumulation of gastropods, ash, and charcoal detritus in layer $C$ suggests another major deposition event. Bed $\mathrm{C}$ registers a probable large forest fire in the upper scarp and wooded areas above the cave. In general, the material from the major events indicated by beds $C, E$, and $F$, was very poorly sorted with well-preserved fossils, seeds, and plant material. This suggests that these layers may represent diamicton facies of Gillieson (1986), which could be interpreted as large asynchronous flooding events (McFarlane and Lundberg, 2007), although on a restricted smaller scale. In turn, the slow sedimentation rates, weathering levels, and fly pupae imply longer times of nondeposition, exposure, and erosion. The amalgamated mixture of larger and smaller vertebrates with land gastropods suggests that deposition is largely controlled by turbulent flooding events of moderate energy (Farrand, 2001; McFarlane and Lundberg, 2007). This is further supported by observation. In April 2015, two of us (JO and LPO) experienced a torrential rainstorm under the main doline, but it failed to bring material into the deposit cone, suggesting that the transportation events must be more intense to transport sediment and biological remains into the cave. Interestingly, some of the superficial dates acquired for the upper levels $(n=$ 3: AD 1953-1957) agree with a period of prolonged rainfall and inundation in the region (Pérez Orozco et al., 2017).

\section{Raptors as One of the Deposit-formation Processes}

Tyto furcata, the most common of Cuban nocturnal raptors today (Garrido and Kirkconnell, $2000)$, is a small mammal specialist with a hunting radius between 3 and $\sim 16 \mathrm{~km}$ (Banks, 1965; Andrews, 1990) and is probably one of the major contributors to pellet accumulations in Cuba today (Arredondo and Chirino, 2002; Silva Taboada et al. 2007; Hernández and Mancina, 2011, López Ricardo, 2012) and the major contributor to the formation of the doline deposit.

Generally, raptor pellets provide a good record of local or regional fauna because of their broad spectrum of selectivity of available microfauna (Mikkola, 1983; Andrew, 1990; Kusmer, 1990). In Cuba, pellet studies have shown that such selectivity does not vary significantly across habitats, whether disturbed or natural (HernándezMuñoz and Mancina, 2011). A larger source for bone accumulations that include both natural and raptor-derived faunas widens the diversity of our record. In that sense, our subsample could be a good proxy of a past local or regional land vertebrate fauna.

\section{Faunal Diversity}

The faunas recovered from this assemblage are moderate to highly diverse (83 NTAXA; 71 vertebrates) and somewhat homogeneous (ShannonWeiner index of 2.82). Among the vertebrates, the relative abundance was particularly highest in birds and mammals (Simpson dominance $>0.293$ or 29.3\%), of which Nesophontes and Artibeus spp. made up the largest NISP (Table 6). Individually per stratigraphic interval, the homogeneity index (Shannon-Weiner) and evenness index varied between 1.17 and 1.21 , and 0.81 and 0.83 between interval levels, respectively. The highest being level IV $(1.21 ; 0.83)$, and the lowest level II $(1.17$; 0.81) (Table 6). However, there was a poor negative (linear) correlation $\left(R^{2}=0.395\right)$ between the Shannon-Weiner index and NTAXA. These suggested, nevertheless, that the stratigraphically 
TABLE 6. Diversity indices, evenness, dominance, and chronology for each stratigraphic interval. Overall values are not the averages of each column, but the overall index calculated for the whole fauna. The roman numerals indicate the stratigraphic intervals as discussed in the text. The overall average is given in bold. BC/AD refers to calendar year calibrations.

\begin{tabular}{ccccccccc}
\hline Interval & NTAXA & NISP & $\begin{array}{c}\text { Shannon- } \\
\text { Weiner }\end{array}$ & Simpson's & Fisher-a & Eveness & Dominance & Chronology \\
\hline I & 39 & 469 & 1.18 & 0.653 & 1.12 & 0.814 & 0.525 & AD 1953-1993 \\
II & 38 & 519 & 1.17 & 0.649 & 1.14 & 0.805 & 0.572 & AD 660-770 \\
III & 55 & 929 & 1.18 & 0.653 & 0.99 & 0.812 & 0.481 & AD 605-655 \\
IV & 34 & 409 & 1.21 & 0.664 & 1.18 & 0.839 & 0.545 & BC 40-AD 90 \\
Overall & 73 & 2326 & 2.82 & 0.698 & 1.1075 & 0.233 & 0.53075 & \\
\hline
\end{tabular}

lower and chronologically oldest intervals II and IV were less diverse, whereas the youngest I and III were more diverse and thus less homogeneous, but better representatives of the collective fauna. The Fisher á and Simpson's indices reflect the higher diversity of levels II and IV (Table 6; Figure 13). In this sense, heterogeneity could have been a result of sample recovery variation, overall and between intervals, and the faunal diversity present therein. The NISP of our assemblage nearly reached an NTAXA asymptote after 3000 specimens and over 70 taxa, suggesting that our overall sample size approached maximum diversity in vertebrates expected for the deposit, but not so on individual beds (Figure 13).

A preliminary comparison in NTAXA and NISP between several of Cuba's cave accumulation deposits can help further contrast the richness of the main doline deposit in Cueva de los Nesofontes and characterize the diversity of the assemblage. Even so, any comparison of homogeneity, diversity, and evenness indices among Cuban cave deposits is limited due to the lack of comparable published assemblage details for other caves that allow for such calculations, and because the deposits have a different genesis and were sampled or studied differently (e.g., concentrated on different groups of organisms, as may seem obvious). For example, the assemblages reported with appropriate detail for Cueva de los Masones and Jagüey, in Sancti Spíritus, represents bats (Silva Taboada, 1974), whereas other such as Cueva GEDA in Pinar del Río (Condis, 2005; Mancina and García-Rivera, 2005), and other cave deposits in northwestern Cuba (Orihuela, 2010; Orihuela and Tejedor, 2012) included several groups of vertebrates, but were less diverse in NTAXA (between 20 and 29) with smaller sample collections (between 150 and 430 NISP). Stratigraphic details on NTAXA and NISP variation from other faunally rich cave deposits such as Cueva del Túnel, Cueva del Mono Fósil, or Cueva de los Paredones are not available.

The rarefaction asymptote for Cuevas Blancas (Mayabeque), Masones, and Jagüey deposits extend well beyond the 500 NISP but with lower NTAXA than the deposit reported here. Cueva GEDAS (Condis, 2005), the kitchen midden from Cueva del Gato Jíbaro (Matanzas; Orihuela and Tejedor, 2012; JO unpublish data), and the other deposit reported for Cueva de los Nesofontes (Orihuela, 2010) all cluster behind the 500 NISP level, and lie outside the confidence intervals, which suggests under-sampling (Figure 13).

Our deposit was richer than that of Cuevas Blancas in NTAXA vertebrate diversity ( $n=83$ vs. $59)$, even though this last had a much larger NISP sample size (i.e., 10027 vs. 2326) (Jiménez et al., 2005). Only the midden deposit from Gato Jíbaro and intervals I and III of Cueva de los Nesofontes doline deposit reported here were within the confidence interval of the curve (Figure 13). The remaining assemblages were outside and were less than the 500 NISP mark, also suggesting under-sampling.

The assemblage's diversity has been influenced by our sampling methods and differences in taphonomic aspects such as raptor preference and natural death, but also by reworking and sedimentological processes explained above. In paleontology, one can never have full access to the actual original faunal diversity. But in this sense, our calculations allowed us to quantify diversity and compare it to other important Cuban deposits to see where our assemblage fits and explore what that says about its diversity and formational history. Calculating the diversity indices for each bed and the assemblage of Pit D has permitted us to compare the diversities of each subsample (i.e., each bed), and to infer that the high diversity observed is 


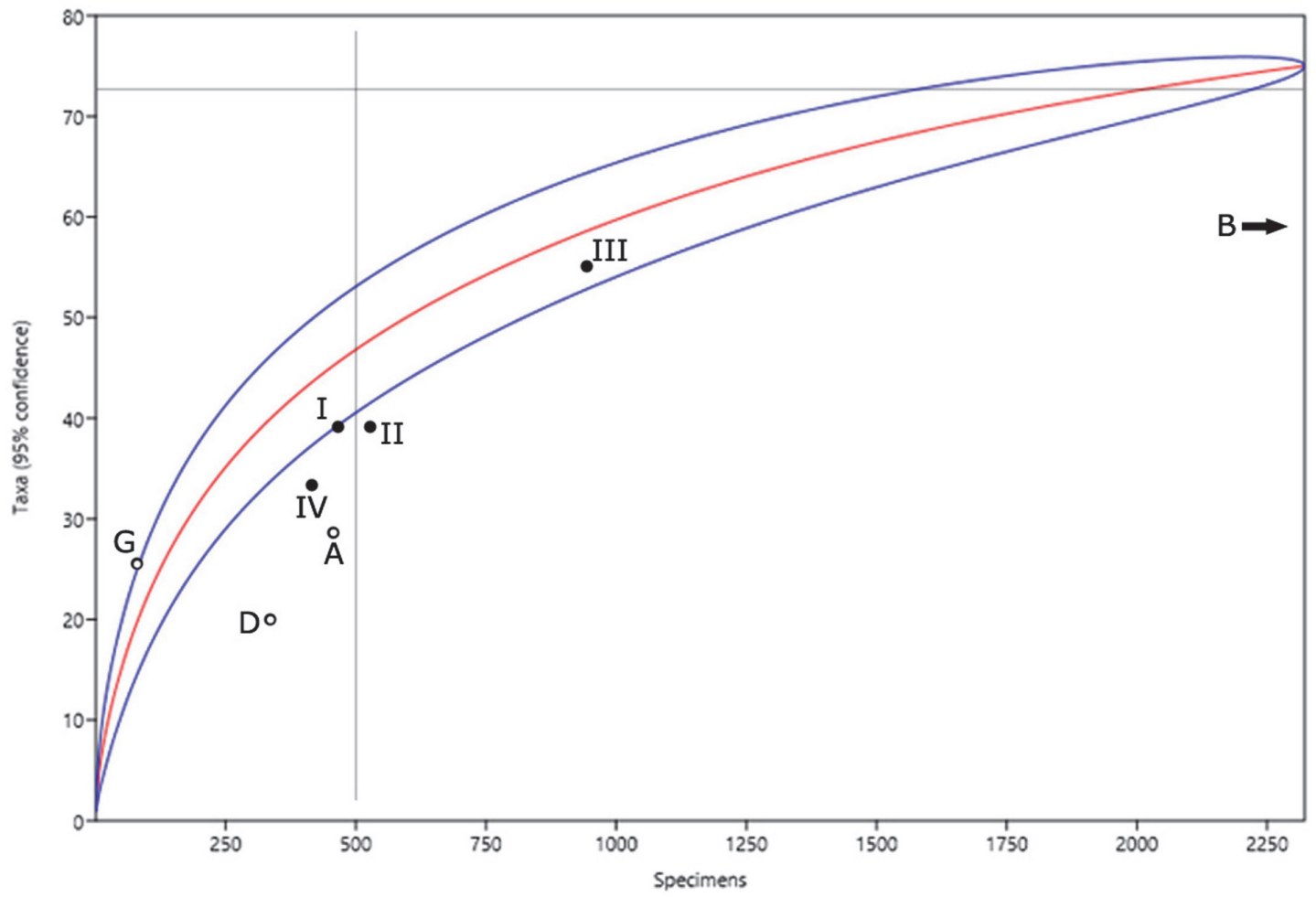

FIGURE 13. Rarefaction curve of Cueva de los Nesofontes doline test pit D (Levels I-IV) in relation to other Cuban deposits. A, Cueva GEDA, Pinar del Río; B, Cuevas Blancas, Mayabeque; D, The Desmodus deposit described in Orihuela (2010). G, from Gato Jíbaro archaeological deposit described in Orihuela and Tejedor (2012). See text for discussion.

partially representative of the local fauna, despite limited sampling and completeness, due to the multiple origins of the biological remains. Thus, suggesting that the presence of several groups or taxa are more than taphonomically or raptor selection, but also controlled by the sedimentological history of the deposit. Moreover, this is one of the most diverse paleontological cave deposits studied from Cuba, and its further study can provide a noteworthy contribution to Cuban and Antillean vertebrate paleontology.

\section{Chronology and Fauna Contemporaneity}

Since the transport and deposition occurred after the deposition of pellets in the upper levels (i.e., primary deposit), the fossils transported and incorporated in the doline deposit below act as terminus post quem (TPQ) to the formation of the beds. Therefore, the depositional/erosional events indicated by the disconformities should date to a time after the age of death of the fossils. In this sense, beds $I$ and $H$ and $B$ and $A$ seem to follow the law of deposition, whereas the events recorded in layers $\mathrm{C}-\mathrm{F}$, may have occurred after the deposition of the layers $H$ and $G$, incorporating an older non-contemporaneous faunal assemblage (Figures 3-4). This is important in the interpretation of the contemporaneity and diachrony of the fauna contained on each bed as a depositional event.

The problem of contemporaneity in fossil assemblages can be further complicated by bioturbation, mixing, layer inversion, down-slope truncation, and further reworking (Farrand, 2001; Bosch and White, 2007; McFarlane and Lundberg, 2007; Patzkowsky and Holland, 2012). Although it is often not practical due to cost or preservation, many specimens from a single layer or a whole stratigraphic sequence should be dated whenever possible (e.g., Semken et al., 2010; Stoetzel et al., 2016). Several studies have suggested that direct dating of associated specimens is required to establish whether specimens in the same bed are radiometrically contemporaneous or diachronous (Stafford et al., 1999; Stoetzel et al., 2016). Sem- 
ken and colleagues showed that diachrony is generally the norm, as they are shown in several North American deposits (Semken et al., 2010), this may be the case in Cuban cave deposits as well.

These issues are of great concern in the study of Cuban bone accumulations or assemblages, the majority of which today lack ${ }^{14} \mathrm{C}$ dates. When available, they are often single dates that do not follow a stratigraphic sequence or form a suite, and, as we have encountered here, may represent diachronous faunas. Thus, assessing contemporaneity between important assemblages and their LADs remains a key factor in the study of extinct or extirpated faunas, but is largely unachievable in Cuba until more dates are available. This is a hindrance to the understanding of Cuban, and thus Greater Antillean, vertebrate extinction and faunal turnover since the late Pleistocene and through the Holocene. A comparison of faunas is further augmented by the lack of confirmed Late Pleistocene dated deposits in Cuba. Several candidate faunas have been postulated (e.g., Cueva del Mono Fósil, Cueva del Túnel or Cueva de los Paredones; Salgado et al., 1992; Gutiérrez Domech et al., 2014) (Figure 1), but only three (Iturralde-Vinent et al., 2000, Breas de San Felipe, El Abrón, and Ciego Montero) have been confirmed (Kulp et al., 1952, Suárez and Díaz-Franco, 2003; Jull et al., 2004; Fiol, 2015). Conversely, many specimens from deposits that were originally thought to be at least late Pleistocene in age have yielded much more recent dates (mHOL-IHOL; MacPhee et al., 1999, 2007; Jull et al., 2004; Jiménez et al., 2005; Steadman et al., 2005; Orihuela, 2010, 2019; Orihuela et al., 2020a).

In our assemblage, the faunas of bed $\mathrm{G}$ and $\mathrm{H}$ (level intervals III-IV) can be interpreted as near contemporaneous, since they differ in slightly less than two sigmas (2o: $100-140{ }^{14} \mathrm{C}$ cal. deviation years). A deviation of a single sigma, usually between $60-70{ }^{14} \mathrm{C}$ cal. years is preferable (Semken et al., 2010), but not available for this deposit. But overall, our dated intervals (e.g., F, E, C, and B) are longer than $1 \sigma$ or $2 \sigma$ and cannot be considered fully contemporaneous. The difference in the diachronic range is between 118 and 138 cal. yrs. before the present, among the faunas of intervals III and IV, and 1958 years between I and II. The diachrony between these intervals highlights wide temporal hiatuses that support a non-continuous deposition, and likely, asynchronous faunas above bed $G$ due to the processes already discussed.

The use of a single date, even if from a single important individual extracted from a controlled stratigraphic unit, can conflict with or non-representative of the age of the whole fauna present in a unit or its stratigraphic association, as is suggested by the ${ }^{14} \mathrm{C}$ age of $P$. vetus from layer $\mathrm{E}$. As is the case in many studies of Antillean land vertebrate paleontology, the interpretation of a single date as a representative of unit-fauna contemporaneity must be considered cautiously. Our data support the use of multiple dates, acquired directly from identifiable bone specimens, in the study of assemblage faunas. Better yet, several specimens should be dated within the same stratigraphic unit, or whole stratigraphic suites when possible to understand depositional regimes, spatial-temporal faunal change, diachrony, and bio-ecological turnover.

However, we consider that even though our dated individuals are not strictly contemporaneous, (as they are not expected to be in a time-averaged, slowly formed deposit), the direct LADs they provide for extinct and extirpated taxa are useful to biogeographical discussions (MacPhee et al., 1999; Silva et al., 2007; Patzkowsky and Holland, 2012). All direct ${ }^{14} \mathrm{C}$ dates provided for the extinct fruit bats $A$. anthonyi and $P$. vetus and the island island-shrews Nesophontes spp. provide evidence of their survival/existence, well into the very late Holocene of Cuba. The chronological and stratigraphic evidence suggests that the studied deposits are about 2000 years old, at least to the level excavated and thus includes fauna from well within the pre-Columbian interval (Morgan and Woods, 1986; Cooke et al., 2017). Furthermore, this indicates not only post-Pleistocene-early Holocene survivorship but also wider distribution ranges that persisted for several thousands of years of climate variations and human coexistence into the late Holocene. Further supporting the time-lagged, group-specific asynchronous extinctions hypothesized by MacPhee and colleagues (1999), which have received growing support in Cuba (Jiménez et al., 2005; Steadman et al., 2005; Orihuela, 2010, 2019; Orihuela and Tejedor, 2012; Borroto-Páez and Mancina, 2017; Orihuela et al., 2020a).

\section{Fauna Temporal-spatial Distribution}

Several of our fauna records indicate a wider distribution beyond current limits for several species that lasted well after 2000 years before the present. These include the anole lizard Anolis cf. chamaeleonides, the woodpecker Colaptes fernandinae (or auratus), the Cuban parakeet Psittacara eups, and crow Corvus which are today locally extinct in the region surrounding Palenque. These represent past extralimital records for species 
whose distributions lie currently far from the deposit (Garrido and Kirkconnell, 2000; Rodríguez Schettino et al., 2013; Orihuela, 2013). Other remains constitute the first pre-Columbian, paleontological records for Progne cf. subis, Tachycineta bicolor, and Cathartes aura. Cathartes aura, Corvus sp, and Psittacara eups have been reported from colonial contexts of the 16th and 18th centuries of La Habana Vieja (Old Havana) (Jiménez and Arrazcaeta, 2008, 2015). The extralimital presence of Corvus sp. in the colonial contexts of the old city of La Habana seems to support a recent range constriction likely related to deforestation (Jiménez and Arrazcaeta, 2008; Orihuela, 2013). Cathartes aura was initially reported from a supposed late Pleistocene deposit of Cueva del Túnel, in Mayabeque province (Acevedo et al., 1975; Acevedo and Arredondo, 1982). That report was challenged by Suárez (2001), who identified those specimens as modern (Jiménez and Arrazcaeta, 2008), thus deleting the species from the fossil record of Cuba. Moreover, Suárez (2001) indicated the existence of an undescribed species of Cathartes. The turkey vulture was observed and sketched by a British soldier during the siege of Havana city in the summer of 1762 (Fletcher, 17571765, p. 255).

All the rodent species had already been reported for the region and do not constitute new records (Jiménez et al., 2005; Silva Taboada et al., 2007; Orihuela and Tejedor, 2012). The Mesocapromys nanus and $M$. kraglievichi are interesting because their fossils support a wider late Holocene distributional range and several thousand-year survival post-Pleistocene climate changes and human inhabitancy in the island. The survival of the extinct hutia $M$. kraglievichi through the pre-Columbian (Amerindian) interval is validated by the direct ${ }^{14} \mathrm{C}$ LAD obtained from a specimen from the Solapa del Megalocnus site, Mayabeque province (Jiménez and $\mathrm{JO}$ unpublish data). This specimen yielded an age of $1780 \pm 50$ rcyr BP from one of the preceramic archaeological contexts, but the specimens found between intervals III and IV of Cueva de los Nesofontes doline assemblage suggest a slightly younger LAD for this species. $M$. nanus is today likely extinct, formerly restricted only to the Zapata swamp, but in the past, it had a wider range (Silva Taboada et al., 2007; Borroto-Páez and Mancina, 2017). A similar extralimital fossil record was recently provided for Mesocapromys sanfelipensis on the mainland of Cuba (Viñola et al., 2018). This taxon is one of three highly localized and endangered pygmy hutias; found today exclusively on several keys of the Cuban archipelago (BorrotoPáez, 2011; Mancina, 2012).

Bats and Nesophontes were the most abundant vertebrates in the assemblage. Yet, several of their species were rare and appeared only at specific intervals or beds, such as Nesophontes cf. longirostris. The smaller $N$. micrus dominated this genus' frequency, with more than 600 NISP representing at least 62 individuals (MNI) present at all intervals. But, individuals of $N$. major were slightly more abundant (Tables 3-4). Of all Nesophontes species, $N$. cf. longirostris was the scarcest, further supporting the rarity of this species (Anthony, 1919). Over 2000 near-complete crania of Nesophontes spp. were formerly extracted from the 1985 excavation alone, making this one of the richest Nesophontes bone accumulations reported from Cuba (Vento Canosa, 1990).

The bats were especially numerous and diverse. The 18 taxa recorded here represent more than half of the known Cuban bat fauna. The taxonomic diversity of bats increases to 21 species if other species documented for this cave are counted (i.e., Desmodus rotundus, Lasiurus insularis, and Chilonatalus macer in Orihuela, 2010; Orihuela et al., 2020b).

The assemblage was particularly rich in frugivorous bats $B$. nana, Phyllonycteris poeyi, $A$. jamaicensis, and $P$. falcatus, whereas the insectivorous bats Eptesicus fuscus, Tadarida brasiliensis, Mormoops blainvillei, Pteronotus parnelli, and Macrotus waterhouseii were less common (Table 3 ). This could be a result of predator selection. The predators that contributed to the pellet-derived deposit seem to have targeted small or mediumsized gregarious species with stationary feeding habits (phyllostomids) or species that had accessible roosts (molossids). Aerial, fast-flying insectivores such as the molossids, and the larger fish and blood-feeders (e.g., Noctilio and Desmodus) hardly ever occur in owl pellet deposits, which in part can explain their rarity in Cuba's raptor-derived bone deposits.

The bat Molossus molossus was represented in our assemblage by three partial skulls with evidence of predation and digestion found only in the uppermost two layers $(A-B)$ of the first interval (Level I). The rarity of $M$. molossus in our assemblage can be the result of a more recent adaptation of both M. molossus and raptors such as Tyto furcata. Molossus species are rare in the Cuban Quaternary cave deposits likely because before European arrival these species roosted in trees or 
crevices, which are not prone to intense preservation.

\section{Coexistence and Competition}

Specimens of Artibeus anthonyi and Artibeus jamaicensis occurred in direct association within the same layer unit and throughout two intervals (level III and IV). Phyllops vetus and Phyllops falcatus occurred together only at interval level III (beds $G$ and $H$ ). Interestingly, in bed $E$ of interval II, which yielded the direct date for $P$. vetus and the oldest ${ }^{14} \mathrm{C}$ available for the assemblage, the two Phyllops species did not coincide. In the youngest interval (level I), neither the extinct $A$. anthonyi nor $P$. vetus occurred, suggesting that by then they were not predated by raptors, were rare to appear in the record, or already extinct. Nonetheless, this supports a very late Holocene extinction for these two species. Moreover, this record suggests that today's most endangered and rarest of Cuban bats, Natalus primus and Antrozous koopmani, had much better distribution on the island that lasted up to very recently.

The direct ${ }^{14} \mathrm{C}$ date on $A$. anthonyi reported for this interval suggests that it is highly probable that both Artibeus species coexisted for several thousand years. It was recently considered that these taxa did not coexist in the Holocene of Cuba for lack of direct evidence (Balseiro et al., 2009; Turvey and Fritz, 2011). In a few deposits where $A$. anthonyi occurred, A. jamaicensis was not found, and when found, the fossils seemed to be non-contemporaneous. But this has not been the case in others. H.E. Anthony, in the original description of the specimens from Cueva del Indio in Daiquirí, Eastern Cuba, that was later identified as Artibeus anthonyi by Woloszyn and Silva Taboada (1976), mentioned the occurrence of both Artibeus species, but these specimens have not been dated.

Until now, a direct radiocarbon date on Artibeus anthonyi was unavailable, but other evidence already suggested coexistence and survival well into the late Holocene of Cuba (Jiménez et al., 2005; Orihuela, 2010; Condis, 2005). Recently, Condis reconsidered the temporal coexistence of several of Cuba's extinct bats in Cueva GEDA, including Cubanycteris silvai, $P$. vetus, A. jamaicensis, and $A$. anthonyi (Condis, 2005). Artibeus anthonyi, $P$. vetus, M. megalophylla, and $A$. koopmani have been reported in deposits dated between the late Pleistocene $(21,474-20,050 \mathrm{BP}$, of Cueva El Abrón, Suárez and Díaz-Franco, 2003; Fiol, 2015), the early-mid Holocene of Cuevas Blancas (7044-6504 BP, in Jiménez et al., 2005) or

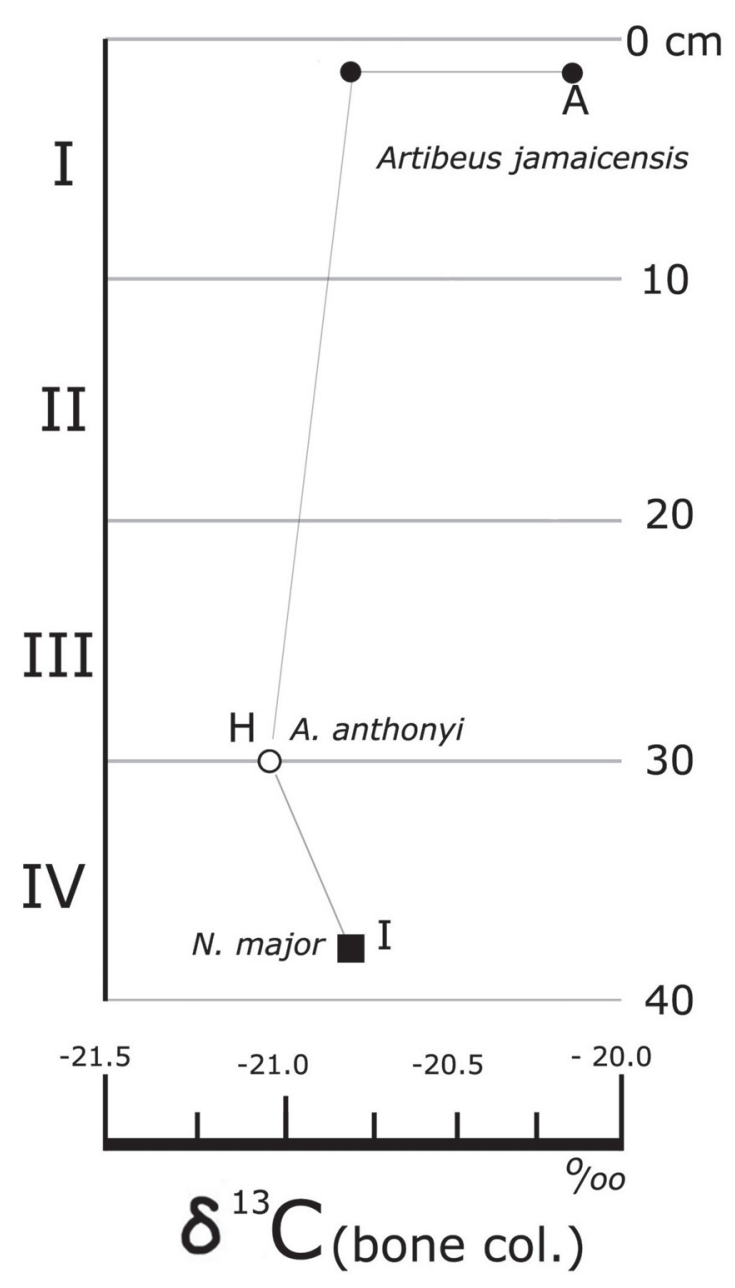

FIGURE 14. Carbon stable isotopes signals from Nesophontes (filled square) and Artibeus spp. (open and closed circles), analyzed from bone collagen) at shown intervals.

further yet, in the very late Holocene (Orihuela, 2010; Orihuela and Tejedor, 2012; Orihuela et al., 2020a, 2020b). This supports their somewhat continuous presence in the fauna since the LGM and throughout most of the Holocene, to the very late Holocene.

Woloszyn and Silva Taboada (1977) suggested that the extinction of $A$. anthonyi was caused by competition, as could be postulated for $P$. vetus and $P$. silvai. However, this hypothesis lacks confirmatory evidence (Balseiro et al., 2009). With the stable isotope values acquired from the bone collagen and tooth apatite extracted from $A$. jamaicensis in comparison to $A$. anthonyi specimens, we are in a better position to discuss the competition hypothesis.

The carbon isotopes do not indicate a substantial trophic variance between the species 
(Table 2; Figure 14). Artibeus anthonyi and $A$. jamaicensis had a similar diet and occupied a similar niche, as suggested by their isotopic values: $A$. anthonyi $\left(\delta^{13} \mathrm{C}\right.$ _col.: $-21.1 \%$ and $\delta^{13} \mathrm{C}$ _apt.: $11.0 \%$ ) and $A$. jamaicensis $\left(\delta^{13} \mathrm{C} \_\right.$col.: -20.1 and $20.7 \%$, plus $\delta^{13} \mathrm{C}$ _apt.: -8.1 and $-9.9 \%$ ). These suggest that diet being similar, could have been an important source of competition; the intensity of the competition depending on their level of resource partitioning or difference in foraging strategies is yet unknown, and only here incipiently investigated and requiring further data.

Moreover, our Artibeus $\delta^{13} \mathrm{C} \_c o l$. values were lower than those reported by Rex and colleagues for $A$. jamaicensis $(-25.6 \pm 0.55 \mathrm{SD}, \mathrm{n}=17)$ and $A$. lituratus (-25.2 $\pm 0.46 \mathrm{SD}, \mathrm{n}=29$ ) (Rex et al., 2011, p. 221). The slightly smaller isotopic yield of $A$. lituratus could suggest a slight vertical stratification in niche partitioning between these two species in Neotropical forests, following the hypothesis that smaller bats prefer understory resources, whereas larger species prefer larger fruits of the canopy (Findley, 1993; Bonaccorso et al., 2007; Pereira et al., 2010). Artibeus jamaicensis generally feed in the forest understory, commonly at ground level, whereas $A$. lituratus preferred a higher canopy level (McNab, 1971; Herrera et al., 2001; Silva et al., 2008; Rex et al., 2011). However, this was not overall supported. Rex and colleagues reported that there could be up to $\sim 6.8 \%$ carbon isotope variation between syntopic species and concluded that there was no vertical stratification for these and other South American forest phyllostomids (Rex et al., 2011). This 6.8\%o value is much greater than the one we report for $A$. jamaicensis and $A$. anthonyi (Table 2, Figure 14). Thus, it remains probable that syntopic phyllostomids such as $A$. jamaicensis and $A$. anthonyi explored all vertical forest levels and niches. The same phenomenon could have occurred among other extinct phyllostomids in Cuba. The size difference between $A$. jamaicensis and $A$. anthonyi is not considerable, and both can be classified as large short-faced fruit consumers (Silva Taboada, 1979). In their case, sympatry and minor habitat partitioning could have led to more competition in foraging for the same resources in the same habitats.

Sympatry between the extant syntopic Cuban mormoopids and other Antillean nectarivorous phyllostomids, in which species presented differences in feeding apparatus, wing morphology, flight patterns, foraging behavior, and spatial segregation, probably facilitated resource partitioning (McNab, 1971; Herrera et al., 2001; Mancina and
Herrera, 2010; Mancina et al., 2012; Soto-Centeno et al., 2014) and thus could have decreased competition.

But this does not seem to be the case for Cuban Artibeus. Based on our few isotope values we hypothesize that $A$. jamaicensis and $A$. anthonyi had a similar diet and occupied similar habitats. In that sense, it is probable that $A$. anthonyi and $A$. jamaicensis, as could be also postulated for Phyllops spp., shared similar habitats and diets, because differences between the carbon and oxygen isotope values are likely not reflective of significant spatial segregation or foraging strategy. A higher level of competition in foraging habitats between these taxa could have pushed the rarer $A$. anthonyi and $P$. vetus/silvai closer to extinction.

In turn, these situations could help explain the coexistence of several extinct Cuban bats for a few thousand years and provide a window into their interaction and extinction. We consider $A$. anthonyi rarer because in the cases in which both species occur, $A$. jamaicensis is by far the most common species of the two, as is the case in assemblages from Cueva de los Nesofontes (Orihuela, 2010; this work), Cueva GEDA (Condis, 2005; Balseiro et al., 2009) and Cuevas Blancas (Jiménez et al., 2005). Although, this apparent variation in abundance could be a taphonomic artifact, such as raptor preference, and not reflective of their natural abundance. However, further isotopic analyses are required to corroborate these preliminary observations.

\section{Paleoenvironmental Reconstruction Gleaned from Fauna and Isotopes}

The presence of the birds Sturnella magna, Melanerpes superciliaris, Corvus sp., and Colaptes woodpeckers suggest the presence of savannas and grasslands and nearby dry semideciduous forests. Similar findings were reported for Cuevas Blancas, several dozen kilometers to the southwest of Palenque (Jiménez et al., 2005). These are habitats that are today reduced or replaced on the island, but still available over some of the karst terrains. The dove Geotrygon chrysia suggests dry forests with little undergrowth, and Psittacara eups undisturbed forests and palm grove savannas (Garrido and Kirkconnell, 2000). The regular transient woodpeckers Sphyrapicus varius, the swallow Tachycineta sp., and the martin Progne sp. support the presence of seasonal transient species in the assemblage. This mosaic of available habitats agrees with the former vegetation hypothesized for the region (Marrero, 1972; Del Risco 
Rodríguez, 1989). The pollen, spores, and seeds registered from this deposit are yet to be studied but can provide a better record of vegetation change in the area when available (Figure 11).

The carbon and oxygen isotopes aid in the interpretation of past habitats and microenvironments (Lee-Thorp et al., 1989; Bocherens et al., 1996; MacFadden et al., 1996). Habitats with a greater proportion of $\mathrm{C} 4$ vegetation, such as grasslands and savannahs, generally yield higher $\delta^{13} \mathrm{C}$ (more positive) values, whereas habitats with higher tree cover (riverine woodlands) tend to have lower (more negative) values. Mixed habitats yield intermediate values (Leichliter et al., 2016; Keicher et al., 2017). The $\delta^{13} \mathrm{C}$ values we obtained from the analyzed remains of Artibeus sp. and N. major are intermediate (Table 2, Figure 14), suggest that these species lived in riverine woodlands and mixed woodland habitats. In this sense, the slight $\delta^{13} \mathrm{C}$ variation between the Cuban Artibeus spp. $\left(\delta^{13} C \_c o l .:-21.1\right.$ and $-20.1 \%$ ) discussed above suggests that $A$. jamaicensis and $A$. anthonyi probably preferred similar forest microhabitats within mixed woodlands and riverine woodlands.

Nesophontes major seems to have inhabited similar habitats. Based on $\delta^{13} \mathrm{C} \_$col. values reported for $N$. micrus by MacPhee et al. (1999, p. $16)$, which varied between -18.9 and $-19.7(n=2)$, we infer that there might have been microhabitat segregation or resource partitioning (slightly different dietary niches) between the Cuban Nesophontes species, with $N$. major preferring mixed woodlands with more tree cover and $N$. micrus preferring grasslands and savannahs. If confirmed by further tests, this observation could explain the higher frequency of $N$. micrus relative to $N$. major observed in our assemblage. Even though $N$. micrus is smaller, it would have been easier to capture by nocturnal raptors, such as T. furcata, which prefer to hunt in more open terrain (Andrews, 1990; López Ricardo, 2012).

In terms of diet, the single acquired nitrogen and carbon isotope value suggest that individuals fed on millipedes, earthworms, maybe fungi and fruits (see similar interpreted signals in Reid et al., 2013; Eckrich et al., 2018). Based on this we hypothesize that Nesophontes species were probably omnivores, occasionally feeding on beetles or millipedes attracted to decomposing pellets accumulated at the raptor roosts. Their tooth marks have been identified on the bones present on owl pellet biological remains (Orihuela et al., 2016; this paper). However, the carrion signal acquired from scavenging is not clear in our isotope data. Our isotope signals for Nesophontes could be masked by enrichment from feeding on necrophagic arthropods (Hocking et al., 2007).

Once more, many more analyses are needed to explore habitat segregation and diet of these vertebrates. Thus, is probable that niche overlap could have also existed between these sympatric taxa. Other sources of variation could include metabolic and isotope fractionation differences (enrichment fluctuations) among taxa, body mass, trophic level, and individual habitat preferences, as has been shown for soricid shrews (Baugh et al., 2004; Keicher et al., 2017) could further mask the isotope signals. Nevertheless, the isotopes provide an additional, here incipiently explored, source of insight that can explain Nesophontes spp. habitat preference, diet, and competition to better explain their extinction.

The presence of mormoopid and vampire bats suggests an overall warm climate during the time of deposition since these species do not inhabit boreal regions and their distribution in the Neotropics is limited by temperature (Vaughan and Bateman, 1970; McNab, 1973; Bonaccorso et al., 1992). This is supported by the oxygen stable isotopes acquired from bone hydroxyapatite and collagen from remains of the bats $A$. jamaicensis, $A$. anthonyi, and from N. major in several intervals of the deposit (Table 2). Our record suggests a wetter, warmer climate around BC 40-AD 90 and AD 605655 , which agrees with the large, slowly deposited but amalgamated bed sets of intervals IV and III (beds I to $\mathrm{H}$ ), expressive of large flooding depositional events.

A $-0.4 \%$ positive oxygen isotope excursion occurred at AD 660-770, suggestive of drier, colder local conditions, with a subsequent progressive return to warmer, wetter conditions after and up to the present (Figure 15). This profile is comparable to conditions gleaned from the Late Pleistocene speleothem record of Río Secreto, Yucatan (Mexico), between 23 and 23.5 ka (Medina Elizalde et al., 2017) and the temperature deviations (anomalies in Celsius degrees from modern temperature) in the order of -0.6 to -0.2 in Moberg et al. (2005) and Abrantes et al. (2017). The wetter, warmer period that followed also agrees with the data presented by these researchers.

A similar positive excursion, although larger in magnitude, is recorded from lacustrine deposits from Punta Laguna, Lake Chichancanab, and Lake Coba (Hodell et al., 1995; Higuera-Gundy et al., 1999; Curtis et al., 2001, p. 4). These records indicated a major drought between 1500 and 1100 


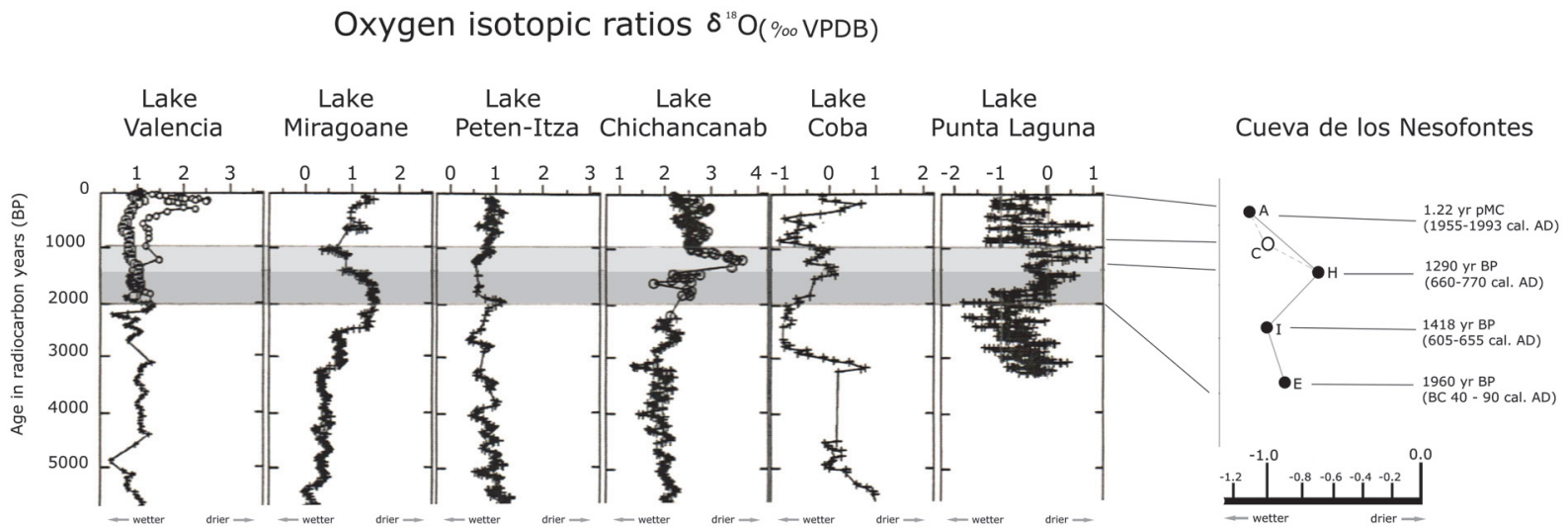

FIGURE 15. Approximation of paleoenvironment conditions through oxygen stable isotopes from Cueva de los Nesofontes test pit D, compared to other circum-Caribbean deposits (modified from Curtis et al., 2001). The grey areas indicate the timeframe of our deposit and its graphical correlation to our data.

years before the present (op. cit.), which can help interpret our positive excursion as a similar, concomitant dry-cold spell.

Paleoclimatic records throughout the Caribbean and circum-Caribbean show a shift from wetter, more mesic conditions during the early-middle Holocene to drier, more xeric conditions during the late Holocene, between 3000 and 1300 year before the present (Hodell et al., 1995; Curtis et al., 2001; Peros et al., 2007). Our data do not agree with the overall tendency towards drier conditions after 2000 cal. yrs. BP interpreted from Cuban coastal lacustrine deposits (Peros et al., 2007; Gregory et al., 2015; Peros et al., 2015), and instead agree with those acquired from cave speleothem records (Pajón et al., 2001; Pajón, 2012; Fensterer et al., 2013), which indicate the inverse. Since our oxygen isotope values were acquired from bat dental apatite, they likely represent the bat's life oxygen record acquired from the local diet and water source (Lee-Thorp et al., 1989; Bocherens et al., 1996; MacFadden et al., 1996). These, in turn, provide us with a very local environmental record. Nevertheless, our contrasting results could also be obscured by the complicated fractionation of oxygen in the sampled bats, bone mineralization, or deposit diagenesis (Bocherens et al., 1996; Lachniet, 2009).

The large accumulation of charcoal and ash of bed $C$ suggests either a natural forest fire or anthropogenic activity in the area; with the charcoal remains brought in by a fast flooding event. Direct ${ }^{14} \mathrm{C}$ date estimates from this level (bed $C$ in Figure 4) indicate it includes fauna younger than 1960 cal. yrs. BP (BC 40-AD 90), but older than 1000 before the present (from Boromys torrei and
Antrozous koopmani specimens in Orihuela et al., 2020a). By then Amerindians, both pre-Arawak "archaic" and Arawaks (agroceramist groups) were already well-established in the area (Tabío and Rey, 1979; Roksandic et al., 2015; Chinique et al., 2016), thus human-caused forest fires cannot be ruled out. Although, based on the lack of archaeological evidence, we consider this as a result of a natural fire on the upper escarpment of the hill. Natural fires are commonly ignited by lightning, as is the case in Cuba (Medina and Alfonso, 2000; Ramos, 2002). Microcharcoal deposits in Cuba (Jiménez et al., 2005) and other parts of the Greater Antilles, although common in some cave and lacustrine deposits, have been difficult to attribute to human action (Burney et al., 1994; Haug et al., 2001; Lane et al., 2013; Caffrey and Horn, 2014). Furthermore, we did not find any archaeological evidence (e.g., tool cut marks) at the doline deposit that could suggest human involvement in these localized fires.

\section{CONCLUSIONS}

The deposit reported and interpreted here from Cueva de los Nesofontes, in northeastern Mayabeque province, provides a rich source of biogeographical and paleoecological information with which to understand the pre-Columbian (Amerindian) environmental history of the late Holocene of Cuba. Through a multidisciplinary and multiproxy approach, we access the formational history and source of the deposit, including the survivorship and coexistence of fauna on a millennial-scale. From these data, we infer that the cone deposit in the main doline gallery is a secondary repository of 
primarily amalgamated, multisource deposit located in the upper levels of the main sinkhole. Although the deposit is mostly pellet-derived, it was slightly mixed over time with organisms by sedimentation and reworking.

The stratigraphic architecture (disconformities and erosional surfaces) that suggest flooding events helped transport sediments and organic remains into the deposition cone below the sinkhole. The deposition was controlled by the slope's incline and is marked by a slow sedimentary regime (slow sedimentary rates) and time-averaged. The oxygen isotopes further suggest a change in the tendency from wet and warm conditions during $B C$ 40-AD 90 to slightly wetter and warmer conditions thereafter. A positive excursion was registered during $A D$ 660-770, before the medieval warm period, that suggests drier and colder local conditions, which does not agree with most other circum-Caribbean records.

The radiocarbon dates yielded by faunal bone collagen indicate that the sampled portion of the deposit is less than 2000 years old, and thus within the pre-Columbian Amerindian interval of the late Holocene. Direct radiocarbon dates from extinct fauna provide last occurrence dates for the extinct fruit bats Artibeus anthonyi and Phyllops vetus, plus the extinct island-shrew Nesophontes major, previously without direct LAD dates. These dates support the inference that some Cuban extinct land mammal taxa, formerly believed to have disappeared during the late Pleistocene-early Holocene, survived well into the late Holocene, and several thousands of years of human presence in the archipelago (MacPhee et al., 1999; Jiménez et al., 2005; Orihuela, 2010; Orihuela and Tejedor, 2012). The association of these species within the dated intervals of the deposit also provides new records supporting a wider distribution for species that are either extinct or severely endangered, such as the bats Natalus primus and Antrozous koopmani. Other taxa, such as Psittacara eups, Corvus, Colaptes, and Solenodon cubanus are locally extinct, and no longer occur in the region, but their presence in the deposit support their existence in the surrounding habitats up to the very late Holocene.

The integration of isotopic data as a proxy for dietary preferences with evidence of niche partitioning may serve to better elucidate unexplored causes of extinction of Antillean land mammals, which we have only recently begun to explore (e.g., Cooke and Crowley, 2018; this work). The information that can be gleaned with simultaneous analyses of assemblage structure and resource partitioning can help elucidate aspects of competition and trophic guild, which when coupled to climatic and anthropogenic factors, can provide an alternative explanation to the asynchronous and taxon-specific extinction of land vertebrates during the Greater Antillean late Holocene.

\section{ACKNOWLEDGMENTS}

We extend my gratitude to L.W. Viñola, R.D.E. MacPhee, and A. Soto-Centeno for revising earlier drafts of this paper, and thanks for their suggestions and discussions. To R. Tykot for his help with the isotope analyses. To M. Peros for providing necessary literature on Caribbean past climate research, and D. Wood, R. Hatfield, and B. Díaz for answering queries on radiocarbon dating. To J.F. Garcell and J. Triana for their help with the necessary permits and logistics. Funding for some of the analyses was provided by a Sigma Xi grant (id: G20141015720649) to JO. Special thanks are due to the original members of the Norbert Casteret, of the Cuban Speleological Society, who first discovered and investigated this deposit. This contribution is possible due to their efforts.

\section{REFERENCES}

Abrantes, F., Rodríguez, T., Rufino, M., Salgueiro, E., Oliveira, D., Gomes, S., Oliveira, P., Costa, A., Mil-Homens, M., Drago, T., and Naughton, F. 2017. The climate of the Common Era off the Iberian Peninsula. Climate of the Past, 13:1901-1918. https://doi.org/10.5194/cp-13-1901-

Acevedo, M. 1992. Geografía Física de Cuba. Editorial Pueblo y Educación, La Habana.

Acevedo, M. and Arredondo, O. 1982. Paleozoografía y geología del cuaternario de Cuba: Características y distribución geográfica de los depósitos con restos de vertebrados. IX Jornada Científica del Instituto de Geología y Paleontológica de la Academia de Ciencias de Cuba, La Habana, Cuba, p. 54-70. 
Acevedo, M., Arredondo, O., and González, N. 1975. La Cueva del Túnel. Editorial Pueblo y Educación, La Habana.

Allen, G.M. 1917. New fossil mammals from Cuba. Bulletin of the Museum of Comparative Zoology, 61:3-12.

Allen, G.M. 1918. Fossil mammals from Cuba. Bulletin of the Museum of Comparative Zoology, 62:133-148.

Allen, H. 1862. Description of two new species of Vespertilionidae and some remarks on the genus Antrozous. Proceedings of the Academy of Natural Sciences of Philadelphia, 14:246248.

Andrews, P. 1990. Owls, Caves and Fossils. University of Chicago Press, Chicago.

Anthony, H.E. 1916. Preliminary diagnosis of an apparently new family of insectivores. Bulletin of the American Museum of Natural History, 35:725-728.

Anthony, H.E. 1917. New rabbit and a new bat from Neotropical regions. Bulletin of the American Museum of Natural History, 37:335-337.

Anthony, H.E. 1919. Mammals collected in Eastern Cuba. Bulletin of the American Museum of Natural History, 41:625-643.

Arredondo, O. 1970. Nueva especie de ave Pleistocénica del Orden Accipitriformes (Accipitridae) y nuevo género para las Antillas. Ciencias Biológicas, 4:1-19.

Arredondo, C. and Chirino, V.N. 2002. Consideraciones sobre la alimentación de Tyto alba furcata (Aves: Strigiformes) con implicaciones ecológicas en Cuba. El Pitirre, 15:16-24.

Baird, S.F. 1865. Review of American birds in the museum of the Smithsonian Institution. Smithsonian Miscellaneous Collections, 181(1):vi-478.

Balseiro, F. 2011. Los murciélagos extintos, p. 170-177. In Borroto-Páez, R. and Mancina, C.A. (eds.), Mamíferos en Cuba. UPC Print Vaasa, Finland.

Balseiro, F., Mancina, C.A., and Guerrero, J.A. 2009. Taxonomic status of Artibeus anthonyi (Chiroptera: Phyllostomidae), a fossil bat from Cuba. Journal of Mammalogy, 90:1487-1494. https://doi.org/10.1644/08-MAMM-A-372R1.1

Banks, R.C. 1965. Some information from barn owl pellets. Auk, 82:506. https://doi.org/10.2307/4083134

Baugh, A.T., West, A.G., Rickart, E.A., Cerling, T.E., Ehleringer, J.R., and Dearing, M.D. 2004. Stable isotope ratios $\left(\delta^{15} \mathrm{~N}\right.$ and $\left.\delta^{13} \mathrm{C}\right)$ of syntopic shrews (Sorex). Southwestern Naturalist, 49:493-500. https://doi.org/10.1894/0038-4909(2004)049\%3C0493:sirnac\%3E2.0.co;2

Behrensmeyer, A.K. 1978. Taphonomic and ecologic information from bone weathering. Paleobiology, 4:150-162. https://doi.org/10.1017/s0094837300005820

Ben-David, M. and Flaherty, E.A. 2012. Stable isotopes in mammalian research: A beginner's guide. Journal of Mammalogy, 93:312-328. https://doi.org/10.1644/11-mamm-s-166.1

Blumenbach, J. F. 1779. Hanbuch der Naturgeschiche. Johann Christian Dieterich, Gottingen.

Bocherens, H., Koch, P.L., Mariotti, A., Geraads, D., and Jaeger, J.J. 1996. Isotopic biogeochemistry $\left({ }^{13} \mathrm{C}, 18 \mathrm{O}\right)$ of mammalian enamel from African Pleistocene Hominid Sites. Palaios, 11:306-318. https://doi.org/10.2307/3515241

Boie, L. 1826. Generalübersicht der ornithologischen Ordnungen, Familien und Gattungen Isis von Oken, 19(10):969-982.

Bonaccorso, F.J., Arends, A., Genoud, M., Cantoni, D., and Morton, T. 1992. Thermal ecology of Mustached and Ghost-Faced Bats (Mormoopidae) in Venezuela. Journal of Mammalogy, 73:365-378. https://doi.org/10.2307/1382071

Bonaccorso, F.J., Winkelmann, J.R., Shin, D., Agrawal, C.I., Aslami, N., Bonney, C., Hsu, A., Jekielek, P.E., Knox, A., Kopach, S.J., Jennings, T.D., Lasky, J.R., Menesale, S.A., Richards, J.H., Rutland, J.A., Sessa, A., Zhaurov, L., and Kunz, T.H. 2007. Evidence for exploitative competition: Comparative foraging behavior and roosting ecology of short-tailed fruit bats (Phyllostomidae). Biotropica, 39:249-256. https://doi.org/10.1111/j.1744-7429.2006.00251.x

Borroto-Páez, R. 2011. Los mamíferos invasores o introducidos, p. 220-241. In Borroto-Páez, R. and Mancina, C.A. (eds.), Mamíferos en Cuba. UPC Print, Vaasa.

Borroto-Páez, R. and Mancina, C.A. 2017. Biodiversity and conservation of Cuban mammals: Past, present, and invasive species. Journal of Mammalogy, 98:964-985. https://doi.org/ 10.1093/jmammal/gyx017

Bosch, R.F. and White, W.B. 2007. Lithofacies and transport of clastic sediment in karstic aquifers, p. 1-22. In Sasowsky, I.D. and Mylroie, J. (eds.), Studies of Cave Sediments. Springer, Dordrecht. https://doi.org/10.1007/978-1-4020-5766-3_1 
Boudagher-Fadel, M.K. 2008. Evolution and Geological Significance of Larger Benthic Foraminifera. Developments in Paleontology and Stratigraphy 21. Elsevier, Amsterdam. https://doi.org/10.1016/s0920-5446(08)00012-5

Brandt, J.F. 1833. De Solenodonte, novo mammalium insectivorum genere. Mémoires de l'Académie Impériale des Sciences de St. Pétersbourg, 6(2):459-478.

Brown, B. 1913. Some Cuban fossils: A hot spring yields up the bones of animals that lived before the advent of Man. The American Museum Journal, 13:221-228.

Buckley, M., Harvey, V.L., Orihuela, J., Mychajliw, A.M., Hadly, E.A., Almonte Milan, J.N., Lawless, C., Chamberlain, A.T., Egerton, V.M., and Manning P.L. 2020. Collagen sequence analysis reveals evolutionary history of extinct West Indies island-shrews. Molecular Biology and Evolution, 37:2931-2943. https://doi.org/10.1093/molbev/msaa137

Burney, D.A., Pigott Burney, L., and MacPhee, R.D.E. 1994. Holocene charcoal stratigraphy from Laguna Tortuguero, Puerto Rico, and the timing of human arrival on the island. Journal of Archaeological Science, 21:273-281. https://doi.org/10.1006/jasc.1994.1027

Cabanis, J.L. 1851. Museum Heineanum: Verzeichniss der ornithologischen Sammlung des Oberamtmann Ferdinand Heine, auf Gut St. Burchard vor Halberstadt. R. Frantz, Halbertstadt.

Caffrey, M. and Horn, S.P. 2014. Long-term fire trends in Hispaniola and Puerto Rico from sedimentary charcoal: A comparison of three records. The Professional Geographer, 67:229241. https://doi.org/10.1080/00330124.2014.922017

Cooke, S.B. and Crowley, B.E. 2018. Deciphering the isotopic niches of new-extinct Hispaniolan rodents. Journal of Vertebrate Paleontology, e1510414. https://doi.org/10.1080/ 02724634.2018.1510414

Cooke, S.B., Dávalos, L.M., Mychajliw, A.M., Turvey, S.T., and Upham, N.S. 2017. Anthropogenic extinction dominates Holocene declines of West Indian mammals. Annual Review Ecology, Evolution and Systematics, 48:301-327. https://doi.org/10.1146/annurevecolsys-110316-022754

Condis, M.M. 2005. Inferencias paleoecológicas sobre especies de la mastofauna cuaternaria cubana, conservadas en el depósito superficial de la Caverna GEDA, Pinar del Rio, Cuba. Unpublished PhD dissertation, Universidad de Pinar del Río, Cuba.

Condis, M.M., Jiménez, O., and Arredondo, C. 2005. Revisión taxonómica del género Nesophontes (Insectivora: Nesophontidae) en Cuba: análisis de los caracteres diagnósticos, p. 95-100. In Alcover, J.A. and Bover, P. (eds.), Proceedings of the International Symposium "Insular Vertebrate Evolution: The Paleontological Approach". Monografies de la Societat d'Història Natural de les Balears, Palma.

Coues, E. 1884. Coues's Key to North American Birds. Second Edition. Estes and Lauriat, Boston.

Cuban Geological Lexicon. 2003. Léxico Estratigráfico de Cuba. Tercera Edición. Instituto de Geología y Paleontología, Servicio Geológico de Cuba, La Habana.

Cuban Geological Lexicon. 2014. Léxico Estratigráfico de Cuba. Cuarta Edición. Instituto de Geología y Paleontología, Servicio Geológico de Cuba, La Habana.

Cuban National Atlas. 1989. Nuevo Atlas Nacional de Cuba. Instituto de Planificación Física, La Habana.

Curtis, J.H., Brenner, M., and Hodell, D.A. 2001. Climate change in the Circum-Caribbean (Late Pleistocene to Present) and implication for regional biogeography, p. 35-54. In Woods, C.A. and Sergile, F. (eds.), Biogeography of the West Indies. Second Edition. CRC Press, Boca Raton. https://doi.org/10.1201/9781420039481-3

de la Torre, C. 1910. Excursión a la Sierra de Jatibonico: osamentas fósiles de Megalocnus rodens o Myomorphus cubensis: comprobación de la naturaleza continental de Cuba a principios de la época Cuaternaria. Anales de la Academia de Ciencias Médicas, Físicas y Naturales de la Habana, 47:204-217.

Del Risco Rodríguez, E. 1989. Mapa a 1:2,000,000 Vegetación Original. Flora y Vegetación 3. Nuevo Atlas Nacional de Cuba. Instituto de Planificación Física, La Habana.

DeNiro, M.J. 1985. Postmortem preservation and alteration of in vivo bone collagen isotope ratios in relation to palaeodietary reconstruction. Nature, 317:806-809. https://doi.org/10.1038/317806a0

Ducloz, C. 1963. Etude géomorphologique de la région de Matanzas, Cuba. Archives de Sciense, 16:351-402. 
Eckrich, C.A., Flaherty, E.A., and Ben-David, M. 2018. Functional and numerical responses of shrews to competition vary with mouse density. PLoS ONE, 13:e0189471. https://doi.org/10.1371/journal.pone.0189471

Farrand, W.R. 2001. Sediments and stratigraphy in rockshelters and caves: A personal perspective on principles and pragmatics. Geoarchaeology, 16:537-557. https://doi.org/10.1002/gea.1004

Fensterer, C., Scholz, D., Hoffman, D.L., Spötl, C., Schröder-Ritzrau, A., Horn, C., Pajón, J.M., and Mangini, A. 2013. Millennial-scale climate variability during the last 12.5 ka recorded in a Caribbean speleothem. Earth and Planetary Science Letters, 361:143-151. https://doi.org/10.1016/j.epsl.2012.11.019

Fiol, S. 2015. La fauna de mamíferos fósiles del depósito paleontológico "El Abrón" (Nivel IX) Pinar del Río, Cuba. Unpublished thesis, Universidad de La Habana, Facultada de Biología, La Habana, Cuba.

Findley, J.S. 1993. Bats: A Community Perspective. Cambridge University Press, Cambridge.

Fletcher, H. 1757-1765. Seven Year's War Journal of the 35th Regiment on Foot. John Carter Brown Library, Rhode Island (unedited manuscript).

Formell, F. and Buguelskiy, Y.R. 1974. Sobre la existencia en Cuba de lateritas ferroniquelíferas redepositadas sobre calizas, p.117-139. In (editor unknown), Contribución a la Geología de Cuba. Publicación Especial Numero 2. Academia de Ciencias de Cuba, La Habana, Cuba.

García, L. and Mancina C.A. 2011. Murciélagos insectívoros, p. 140-165. In Borroto-Páez, R. and Mancina, C.A. (eds.), Mamíferos en Cuba. UPC, Vasa, Finland.

Garrido, O.H. and Kirkconnell, A. 2000. Field Guide to the Birds of Cuba. Cornell University Press, Ithaca.

Geological Society of America. 2009. Geological Rock-Color Chart with Genuine Munsell Color Chips. Munsell Color, Grand Rapids.

Geyh, M.A. and Schleicher, H. 1990. Absolute Age Determination: Physical and Chemical Dating Methods and Their Applications. Springer-Verlag, New York.

Gill, T. 1872. Arrangement of the families of mammals with analytical labels. Smithsonian Miscellaneous Collection, 11(2030):1-98.

Gillieson, D. 1986. Cave sedimentation in the New Guinea highlands. Earth Surface Processes and Landforms, 11:533-543. https://doi.org/10.1002/esp.3290110508

Goldberg, S.L., Novacek, M.J., and Alayón, G. 2017. The history of scientific relations between Cuba and the American Museum of Natural History (AMNH): 160 years of collecting and collaborating (1857-2017). American Museum of Natural History, New York. https://doi.org/10.5531/amnh.pub.0001

González Alonso, H. 2012. Aves, p. 207-267. In González Alonso, H., Rodríguez, L., Rodríguez, A., Mancina, C.A., and Ramos, I. (eds.), Libro Rojo de los Vertebrados de Cuba. Editorial Academia, La Habana.

Gray, J.E. 1821. On the natural arrangement of vertebrose animals. London Medical Repository, $15: 296-310$

Gray, J.E. 1825. An attempt at a division of the family Vespertilionidae into groups. The Zoological Journal, 2(6):242-243.

Gray, J.E. 1838. A revision of the genera of bats (Vespertilionidae) and the description of some new genera and species. Magazine of Zoology and Botany, 2:483-505.

Gregory, B.R.B., Peros, M., Reinhardt, E.G., and Donnelly, J.P. 2015. Middle-late Holocene Caribbean aridity inferred from foraminifera and elemental data in sediment cores from two Cuban lagoons. Palaeogeography, Palaeoclimatology and Palaeoecology, 426:229-241. https://doi.org/10.1016/j.palaeo.2015.02.029

Gutiérrez Domech, M.R., Balado Piedra, E.J., Delgado Carballo, I., Oliva Martin, A., Cardona Muñiz, C.L., and Domínguez Samalea, Y. 2014. Las cuevas de Paredones y del Túnel y la Caverna de Pío Domingo: Principales yacimientos fosilíferos de vertebrados del Pleistoceno en Cuba occidental. Geoinformativa, 8:32-43.

Hammer, Ø., Harper, D.A.T., and Ryan, P.D. 2001. PAST: Paleontological Statistic Software package for education and data analysis. Palaeontologia Electronica, 4.1.4:1-9. https://palaeo-electronica.org/2001_1/past/issue1_01.htm

Haug, G.H., Hughen, K.A., Sigman, D.M., Peterson, L.C., and Röhl, U. 2001. Southward migration of the Intertropical Convergence Zone through the Holocene. Science, 293:13041308. https://doi.org/10.1126/science.1059725 
Hernández de Lara, O., Rodríguez Tápanes, B., and Arredondo, C. 2013. Esclavos y Cimarrones en Cuba: Arqueología Histórica en la Cueva El Grillete. Aspha, Buenos Aires.

Hernández-Muñoz, A. and Mancina C.A. 2011. La dieta de la lechuza (Tyto alba) (Aves: Strigiformes) en hábitats naturales y antropogénicos de la región central de Cuba. Revista Mexicana de Biodiversidad, 82:217-226.

Herrera, L., Hobson, K.A., Mirón, L., Nicte Ramírez, P., Méndez, G., and Sánchez-Cordero, V. 2001. Sources of protein in two species of phytophagous bats in seasonal dry forest: Evidence from stable-isotope analysis. Journal of Mammalogy, 82:352-361. https://doi.org/10.1644/1545-1542(2001)082<0352:SOPITS>2.0.CO;2

Higuera-Gundy, A., Brenner, M., Hodell, D.A., Curtis, J.H., Leyden, B.W., and Binford, M.W. 1999. A $10,300{ }^{14} \mathrm{C}$ record of climate and vegetation change in Haiti. Quaternary Research, 52:159-170. https://doi.org/10.1006/qres.1999.2062

Hodell, D.A., Curtis, J.H., and Brenner, M. 1995. Possible role of climate in the collapse of Classic Maya civilization. Nature, 375:391-394. https://doi.org/10.1038/375391a0

Howard, H. 1929. The avifauna of Emeryville shellmound. University of California Publications in Zoology, 32:301-396.

Hua, Q. and Barbettii, M. 2004. Review of the tropospheric bomb ${ }^{14} \mathrm{C}$ data for carbon cycle modeling and age calibration purposes. Radiocarbon, 46:1273-1298. https://doi.org/10.1017/s0033822200033142

Illigeri, C. 1811. Prodromus Systematis Mammalium Et Avium Additis Terminis Zoographicis Utriusque Classis, Eorumque Versione Germanica. C. Salfeld, Berlin.

Iturralde-Vinent, M. 1969a. Principal characteristics of Cuban Neogene stratigraphy. American Association Bulletin of Petroleum Geologists Bulletin, 53:1938-1955. https://doi.org/10.1306/5d25c891-16c1-11d7-8645000102c1865d

Iturralde-Vinent, M. 1969b. El Neógeno en la provincia de Matanzas, Cuba. Parte General. Publicación Especial del Instituto Nacional de Recursos Hidráulicos, 7:3-30.

Iturralde-Vinent, M. 1977. Los movimientos tectónicos de la etapa de desarrollo platafórmico en Cuba. Informe Científico-Técnico Academia de Ciencias de Cuba, 20:1-24.

Iturralde-Vinent, M. 1988. Naturaleza Geológica de Cuba. Editorial Científico-Técnica, La Habana.

Iturralde-Vinent, M., MacPhee, R.D.E., Díaz-Franco, S., Rojas-Consuegra, R. Suárez, W., and Lomba, A. 2000. Las breas de San Felipe, Quaternary asphalt seep near Martí (Matanzas Province, Cuba). Caribbean Journal of Science, 36:300-313.

Jiménez, O. 1997. Seis nuevos registros de aves fósiles en Cuba. El Pitirre, 10:49.

Jiménez, O. 2001. Registros ornitológicos en residuarios de dieta de los aborígenes precerámicos cubanos. El Pitirre, 14:120-126.

Jiménez, O. and Arrazcaeta, R. 2008. Las aves en la arqueología histórica de La Habana Vieja. Boletín del Gabinete de Arqueología, 7:17-29.

Jiménez, O. and Arrazcaeta, R. 2015. Las aves y su relación con las culturas precolombinas de Cuba. Boletín del Gabinete de Arqueología, 11:141-157.

Jiménez, O., Condis, M.M., and García Cansío, E. 2005. Vertebrados Post-glaciales en un residuario fósil de Tyto alba Scopoli (Aves: Tytonidae) en el Occidente de Cuba. Revista Mexicana de Mastozoología, 9:80-101.

Jiménez, O. and Orihuela, J. In press. Nuevos hallazgos paleobiológicos de aves extintas o en peligro crítico endémicas de cuba, géneros Ara (Psittacidae), Pulsatrix (Strigidae) y Campephilus (Picidae). Novitates Caribaea.

Jull, A.J.T., Iturralde-Vinent, M., O’Malley, J.M., MacPhee, R.D.E., McDonald, H.G., Martin, P.S., Moddy, J., and Rincón, A. 2004. Radiocarbon dating of extinct fauna in the Americas recovered from tar pits. Nuclear Instruments and Methods in Physics Research, B 223/ 224:668-671. https://doi.org/10.1016/s0168-583x(04)00648-2

Keicher, L., O'Mara, M.T., Voigt, C.C., and Dechmann, D.K.N. 2017. Stable carbon isotopes in breath reveal fast incorporation rates and seasonably variable but rapid fat turnover in the common shrew (Sorex araneus). Journal of Experimental Biology, 220:2834-2841. https:// doi.org/10.1242/jeb.159947

Koopman, K.F. and Williams, E.E. 1951. Fossil chiroptera collected by H.E. Anthony in Jamaica 1919-1920. American Museum Novitates, 1519:1-30.

Kulp, J.L., Tryon, L.E., Eckelman, W.R., and Snell, W.A. 1952. Lamont natural radiocarbon measurements, II. Science, 116(3016):409-414. https://doi.org/10.1126/science.116.3016.409 
Kusmer, K.D. 1990. Taphonomy of owl pellet deposition. Journal of Paleontology, 64:629-637. https://doi.org/10.1017/s0022336000042669

Lachniet, M.S. 2009. Climatic and environmental controls on speleothem oxygen-isotope values. Quaternary Science Reviews, 28:412-432. https://doi.org/10.1016/j.quascirev.2008.10.021

Lafresnaye, F. 1839. Quelques oiseaux nouveaux de la collection de M. Charles Brelay, á Bordeaux. Revue Zoologique par La Société Cuvierienne, 1839:97-100.

Lane, C.S., Clark, J.J., Knudsen, A., and McFarlin, J. 2013. Late Holocene paleoenvironmental history of bioluminescent Laguna Grande, Puerto Rico. Palaeogeography, Palaeoclimatology Palaeoecology, 369:99-113. https://doi.org/10.1016/j.palaeo.2012.10.007

Leach, W.E. 1820. Synopsis of the Contents of the British Museum: Eleventh Room. 17th Edition. British Museum, London. https://doi.org/10.5962/bhl.title.144385

Leach, W.E. 1821. The characters of seven genera of bats with foliaceous appendages to the nose. Transactions of the Linnaean Society of London, 13(1):73-82. https://doi.org/10.1111/j.1095-8339.1821.tb00056.x

Leichliter, J.N., Sponheimer, M., Avenant, N.L., Sandberg, P.A., Paine, O.C.C., Codron, D., Codron, J., and Passey, B.H. 2016. Small mammal insectivore stable carbon isotope compositions as habitat proxies in a South African savanna ecosystem. Journal of Archaeological Science: Reports, 8:335-345. https://doi.org/10.1016/j.jasrep.2016.05.013

Lee-Thorp, J.A., Sealy, J.C., and Van Der Merwe, N.J. 1989. Stable carbon isotope ratio differences between bone collagen and bone apatite, and their relationship to diet. Journal of Archaeological Science, 16:585-599. https://doi.org/10.1016/0305-4403(89)90024-1

Linnaeus, C. 1758. Systema Naturae, 10th Edition. Laurentii Salvii, Homiae.

López Ricardo, Y. 2012. Alimentación de la lechuza (Tyto alba furcata) en Cuba central: presas introducidas y autóctonas. Unpublished Ph.D. thesis, Facultad de Biología de la Universidad de La Habana, La Habana, Cuba.

Lyman, R.L. 2008. Quantitative Paleozoology. Cambridge University Press, Cambridge.

MacPhee, R.D.E., Flemming, C., and Lunde, D.P. 1999. "Last occurrence" of the Antillean insectivoran Nesophontes: New radiometric dates and their interpretations. American Museum Novitates, 3261:1-20.

MacPhee, R.D.E., Iturralde-Vinent, M.A., and Jiménez Vázquez, O. 2007. Prehistoric sloth extinctions in Cuba: Implications of a new "last" appearance date. Caribbean Journal of Science, 43:94-98. https://doi.org/10.18475/cjos.v43i1.a9

MacFadden, B.J., Cerling, T.E., and Prado, J. 1996. Cenozoic terrestrial ecosystem evolution in Argentina: Evidence from carbon isotopes of fossil mammal teeth. Palaios, 11:319-327. https://doi.org/10.2307/3515242

McNab, B.K. 1971. The structure of tropical bat faunas. Ecology, 32:352-358. https://doi.org/10.2307/1934596

McNab, B.K. 1973. Energetics and the distribution of vampires. Journal of Mammalogy, 54:131144. https://doi.org/10.2307/1378876

Mancina, C.A. 2012. Mamíferos, p. 268-291. In González Alonso, H. (ed.), Libro Rojo de los Vertebrados de Cuba. Editorial Academia, La Habana, Cuba.

Mancina, C.A. and García-Rivera, L. 2005. New genus and species of fossil bat (Chiroptera: Phyllostomidae) from Cuba. Caribbean Journal of Science, 41:22-27.

Mancina, C.A. and Herrera, L.G. 2010. Disparate feeding strategies used by syntopic Antillean nectarivorous bats to obtain dietary protein. Journal of Mammalogy, 9:960-966. https://doi.org/10.1644/09-mamm-a-323.1

Mancina, C.A., García-Rivera, L., and Miller, B.W. 2012. Wing morphology, echolocation, and resource partitioning in syntopic Cuban mormoopid bats. Journal of Mammalogy, 93:13081317. https://doi.org/10.1644/11-mamm-a-331.1

Marrero, L. 1972. Cuba: Economía y Sociedad Vol. 1. Editorial Playor, S.A., Madrid.

McFarlane, D.A. and Lundberg, J. 2007. Reliquiae Diluvianae Alter: Las interglacial flood deposits in the caves of the West Indies, p. 313-322. In Sasowsky, I.D. and Mylroie, J. (eds.), Studies of Cave Sediments. Springer, Dordrecht. https://doi.org/10.1007/978-1-4020-5766-3_17

Medina Elizalde, M., Burns, S.J., Polanco Martínez, J., Lases Hernández, F., Bradley, R., Wang, H.-C., and Shen, C.-C. 2017. Synchronous precipitation reduction in the American tropics associated with Heinrich 2. Scientific Reports, 7:11216. https://doi.org/10.1038/s41598-017-11742-8 
Medina, T.N. and Alfonso, F.A. 2000. Los incendios forestales causados por descargas eléctricas en Cienaga de Zapata, Matanzas, Cuba. Ciencia Forestal en México, 25:105-113.

Meyer, B. and Wolf, J. 1811. Taschenbuch der deutschen Vögelkunde, oder, Kurze Beschreibung aller Vögel Deutschlands. Verlegt von Friedrich Wilmans, Frankfut am Main.

Miller, G.S. 1916. Bones of mammals from Indian sites in Cuba and Santo Domingo. Smithsonian Miscellaneous Collection, 66:1-10.

Moberg, A., Sonechkin, D.M., Holmgren, K., Datsenko, N.M., and Karlen, W. 2005. Highly variable Northern Hemisphere temperatures reconstructed from low- and high-resolution proxy data. Nature, 433:613-617. https://doi.org/10.1038/nature03265

Morgan, G.S. 1977. Late Pleistocene fossil vertebrates from the Cayman Islands, British West Indies. Unpublished M.S. thesis, University of Florida, Gainesville.

Morgan, G.S. 1994. Late Quaternary fossil vertebrates from the Cayman Islands, p. 465-508. In Brunt, M.A. and Davies, J.E. (eds.), The Cayman Islands: Natural History and Biogeography. Springer, Netherlands. https://doi.org/10.1007/978-94-011-0904-8_22

Morgan, G.S. and Woods, C.A. 1986. Extinction and zoogeography of the West Indian land mammals. Biological Journal of the Linnaean Society, 28:167-203. https://doi.org/10.1111/j.1095-8312.1986.tb01753.x

Nicholson, K.E., Crother, B.I., Guyer, C., and Savage, J.M. 2012. It is time for a new classification of anoles (Squamata: Dactyloidea). Zootaxa, 3477:1-108. https://doi.org/ 10.11646/zootaxa.3477.1.1

Nuñez Jiménez, A. 1989. Medio Siglo Explorando a Cuba (Tomo 1). Imprenta Central de las FAR, La Habana.

Nuñez Jiménez, A. 1998. Geología. Ediciones Mee Graphic Ltd., La Habana.

Nuñez Jiménez, A., Viña, N., Acevedo, M., Mateo, J., Iturralde-Vinent, M., and Graña, A. 1984. Cuevas y Carsos. Editorial Militar, La Habana.

Olsen, S.J. 1979. Osteology for the archaeologist. Papers of the Peabody Museum of Archaeology and Ethnology: Harvard University, 56:1-186.

Orihuela, J. 2010. Late Holocene Fauna from a Cave Deposit in Western Cuba: post Columbian occurrence of the vampire bat Desmodus rotundus (Phyllostomidae: Desmodontinae). Caribbean Journal of Science, 46:297-312. https://doi.org/10.18475/cjos.v46i2.a17

Orihuela, J. 2013. Fossil Cuban crow Corvus cf. nasicus from a Late Quaternary cave deposit in northern Matanzas, Cuba. Journal of Caribbean Ornithology, 26:12-16.

Orihuela J. 2014. Endocranial morphology of the extinct Antillean shrew Nesophontes (Lipotyphla: Nesophontidae) from natural and digital endocasts of Cuban taxa. Palaeontologia Electronica, 17:1-12. https://doi.org/10.26879/369

Orihuela, J. 2019. An annotated list of Late Quaternary extinct birds of Cuba. Ornitología Neotropical, 30:57-67.

Orihuela, J. and Pérez Orozco, L. 2015. Descubrimiento de posible arte rupestre en cueva de la Loma El Palenque, Alturas Habana-Matanzas, Cuba. Cuba Arqueológica, 8:57-58.

Orihuela, J. and Tejedor, A. 2012. Peter's ghost-faced bat Mormoops megalophylla (Chiroptera: Mormoopidae) from a pre-Columbian archeological deposit in Cuba. Acta Chiropterologica, 14:63-72. https://doi.org/10.3161/150811012x654277

Orihuela, J., Jiménez Vázquez, O., and Garcell, J.F. 2016. Modificaciones tafonómicas en restos óseos: ejemplos arqueológicos y paleontológicos de Mayabeque y Matanzas, Cuba. Cuba Arqueológica, 9:13-36.

Orihuela, J., Viñola, L.W., Jiménez Vázquez, O., Mychajliw, A., Hernández de Lara, O., Lorenzo, L., and Soto-Centeno, J.A. 2020a. Assessing the role of humans on Greater Antillean land vertebrate extinctions: new insights from Cuba. Quaternary Science Reviews, 249:106597 https://doi.org/10.1016/j.quascirev.2020.106597

Orihuela, J., Viñola, L.W., and Viera, R. 2020b. New bat locality records from Cuba with emphasis on the province of Matanzas. Novitates Caribaea, 14:96-116. https://doi.org/ 10.33800/nc.vi15.218

Orr, R.T. and Silva Taboada, G. 1960. A new species of bat of the genus Antrozous from Cuba. Proceedings of the Biological Society of Washington, 73:83-86.

Pajón, J.M. 2012. Paleoclimas y paleohuracanes en el Gran Caribe. Potencialidades de investigación-cooperación científica. LASA, San Francisco, p. 1-14. 
Pajón, J.M., Hernández, I., Macle, J., and Ortega, F. 2001. Periods of wet climate in Cuba: Evaluation of expression in karst of Sierra de San Carlos, p. 217-226. Markgraf, V. (ed.), Interhemispheric Climate Linkages, Present and Past Interhemispheric Climate Linkages in the Americas and their Societal Effects. Academic Press, Elsevier, Netherlands. https://doi.org/10.1016/b978-012472670-3/50016-1

Patzkowsky, M.E. and Holland, S.M. 2012. Stratigraphic Paleobiology: Understanding the Distribution of Fossil Taxa in Time and Space. University of Chicago Press, Chicago, USA.

Peters, W. 1861. Solenodon cubanus. Monatsbericht der Königlich-Preussischen Akademie der Wissenschaften zu Berlin, 1861(2):169.

Peters, W. 1865. Abbildungen zu einer Monographie der Chiropteren vor und gab eine ubersicht der von oihm befolgten systematischen Ordnung der hieher gehorigen Gattungen. Monatsberichte der Königlichen Preussische Akademie des Wissenschaften zu Berlin, 1865:256-258.

Pereira, M.J.R., Marques, J.T., and Palmeirim, J.M. 2010. Vertical stratification of bat assemblages in flooded and unflooded Amazonian forests. Current Zoology, 56:469-478. https://doi.org/10.1093/czoolo/56.4.469

Pérez Orozco, L., González Arestuche, L.R., Orihuela León, J., and Viera Muñoz, R. 2017. Matanzas en el Visor del Tiempo. Editorial Boloña, La Habana.

Peros, M., Gregory, B., Matos, F., Reinhardt, E., and Desloges, J. 2015. Late-Holocene record of lagoon evolution, climate change, and hurricane activity from southeastern Cuba. The Holocene, 25:1483-1497. https://doi.org/10.1177/0959683615585844

Peros, M.C., Reinhardt, E.G., Schwartz, H.P., and Davis, A.M. 2007. High-resolution paleosalinity reconstruction from Laguna de la Leche, north coastal Cuba, using $\mathrm{Sr}, \mathrm{O}$, and $\mathrm{C}$ isotopes. Palaeogeography, Palaeoclimatology, Palaeoecology, 245:535-550. https://doi.org/10.1016/j.palaeo.2006.09.006

Peterson, O.A. 1917. Report upon a fossil material collected in 1913 by the Messrs. Link in a cave in the Isle of Pines. Annals of the Carnegie Museum, 11:359-361.

Rafinesque, C.S. 1815. Analyse de la nature ou, Tableau de l'univers et des corps organisés. Published by the author. https://doi.org/10.5962/bhl.title.106607

Ramsey, C.B. 2017. OXCAL-4.3.2.

Reid, R.E.B, Greenwald, E.N., Wang, Y., and Wilmers, C.C. 2013. Dietary niche partitioning by sympatric Peromyscus boylii and $P$. californicus in a mixed evergreen forest. Journal of Mammalogy, 94:1248-1257. https://doi.org/10.1644/13-mamm-a-104.1

Remsen, J.V., Schirtzinger, E.E., Ferraroni, A., and Silveira, L.F. 2013. DNA-sequence data require revision of the parrot genus Aratinga (Aves: Psittacidae). Zootaxa, 3641:296-300. https://doi.org/10.11646/zootaxa.3641.3.9

Rex, K., Michener, R., Kunz, T.H., and Voight, C.C. 2011. Vertical stratification of Neotropical leaf-nosed bats (Chiroptera: Phyllostomidae) revealed by stable carbon isotopes. Journal of Tropical Ecology, 27:211-222. https://doi.org/10.1017/s0266467411000022

Rivero, M. and Arredondo, O. 1991. Paralouatta varonai, a new Quaternary platyrrhine from Cuba. Journal of Human Evolution, 21:1-11. https://doi.org/10.1016/0047-2484(91)90032-q

Rodríguez Schettino, L., Mancina, C.A., and Rivalta González, V. 2013. Reptiles of Cuba: Checklist and geographic distributions. Smithsonian Herpetological Information Service, 144:1-92. https://doi.org/10.5479/si.23317515.144.1

Rzebik-Kowalska, B. and Woloszyn, B.W. 2012. New data on Nesophontes subfossil populations from Cuba and Isla de la Juventud (Cuba). Neues Jahrbuch für Geologie und Paläontologie Abhandlungen, 263(2):155-166. https://doi.org/10.1127/0077-7749/2012/0220

Salgado, E.J., Calvache, D.G., MacPhee, R.D.E., and Gould, G.C. 1992. The monkey caves of Cuba. Cave Sciences, 19:25-28.

Saussure, M.H. 1860. Notes sur quelques mammifères du Mexique. Revue et Magasin de Zoology Pure et Appliquée, 12(2):281-293.

Semken, H.A., Graham, R.W., and Stafford, T.W. 2010. AMS ${ }^{14} \mathrm{C}$ analysis of Late Pleistocene non-analog faunal component from 21 cave deposits in southeastern North America. Quaternary International, 217:240-255. https://doi.org/10.1016/j.quaint.2009.11.031

Silva, A.G., Gaona, O., and Medellín, R.A. 2008. Diet and trophic structure in a community of fruit-eating bats in lacandon forest, México. Journal of Mammalogy, 89:43-49. https://doi.org/10.1644/06-mamm-a-300.1 
Silva Taboada, G. 1974. Fossil Chiroptera from cave deposits in central Cuba, with a description of two new species (genera Pteronotus and Mormoops) and the first West Indian record of Mormoops megalophylla. Acta Zoologica Cracoviensia, 19:33-73.

Silva Taboada, G. 1976. Historia y actualización taxonómica de algunas especies antillanas de murciélagos de los géneros Pteronotus, Brachyphylla, Lasiurus, y Antrozous. Poeyana, 153:1-24.

Silva Taboada, G. 1979. Los Murciélagos de Cuba. Editorial Academia, La Habana.

Silva Taboada, G., Suárez, W., and Díaz-Franco, S. 2007. Compendio de los Mamíferos terrestres autóctonos de Cuba vivientes y extinguidos. Ediciones Boloña, La Habana.

Silva Taboada, G. and Vela Rodríguez, H. 2009. Actualización taxonómica y distribucional de los murciélagos de Cuba (1). El Explorador, 61:1-5.

Simmons, N.B. 2005. Order Chiroptera. In Wilson, D.E. and Reeder, D.M. (eds.), Mammal Species of the World: A Taxonomic and Geographic Reference. 3rd Edition. Smithsonian Institution Press, Washington D.C.

Shipman, P. 1981. Life History of a Fossil: An Introduction to Taphonomy and Paleoecology. Harvard University Press, Cambridge.

Short, L.L. 1965. Variation in West Indian flickers (Aves: Colapters). Bulletin of the Florida State Museum, 10:1-42.

Smith, C.H. 1842. Introduction to Mammals. The Naturalist's Library. Vol. 12. W. Jardine, London.

Soto-Centeno, J.A., O'Brien, M., and Simmons, N.B. 2015. The importance of late Quaternary climate change and karst on distributions of Caribbean mormoopid bats. American Museum Novitates, 3847:1-32. https://doi.org/10.1206/3847.1

Soto-Centeno, J.A., Phillips, D.L., Kurta, A., and Hobson, K.A. 2014. Food resource partitioning in nectar feeding bats on Puerto Rico. Journal of Tropical Ecology, 30:359-369. https://doi.org/10.1017/s0266467414000145

Stafford, T.W., Semken, H.A., Graham, R.W., Klippel, W.F., Markova, A., Smirnov, N.G., and Southon, H. 1999. First accelerator mass spectrometry ${ }^{14} \mathrm{C}$ dates documenting contemporaneity of nonanalog species in the late Pleistocene mammal communities. Geology, 27:903-906. https://doi.org/10.1130/0091-7613(1999)027<0903:FAMSCD>2.3.CO;2

Steadman, D.W., Martin, S.P., MacPhee, R.D.E., Jull, A.T.J., McDonald, H.G., Woods, C.A., Iturralde-Vinent, M., and Hodgins, G.W.L. 2005. Asynchronous extinction of late Quaternary sloths on continents and islands. Proceedings of the National Academy of Science, 102:11763-11768. https://doi.org/10.1073/pnas.0502777102

Stoetzel, E., Royer, A., Cochard, D., and Lenoble, A. 2016. Late Quaternary changes in bat paleodiversity and paleobiogeography under climatic and anthropogenic pressure: New insights from Marie-Galante, Lesser Antilles. Quaternary Science Reviews, 143:150-174. https://doi.org/10.1016/j.quascirev.2016.05.013

Suárez, W.S. 2001. A reevaluation of some fossils identified as vultures (Aves: Vulturidae) from Quaternary cave deposits of Cuba. Caribbean Journal of Science, 37:110-111.

Suárez, W.S. and Díaz-Franco, S. 2003. A new fossil bat (Chiroptera: Phyllostomidae) from a Quaternary cave deposit in Cuba. Caribbean Journal of Science, 39:371-377.

Suárez, W.S. and Olson, S.L. 2015. Systematics and distribution of the giant fossil barn owls of the West Indies (Aves: Strigiformes: Tytonidae). Zootaxa, 4020:533-553. https://doi.org/10.11646/zootaxa.4020.3.7

Taylor, A.M. and Goldring, R. 1993. Description and analysis of bioturbation and ichnofabric. Journal of the Geological Society, 150:141-148. https://doi.org/10.1144/gsjgs.150.1.0141

Turvey, S.T. and Fritz, S.A. 2011. The ghosts of mammals past: Biological and geographical patterns of global mammalian extinction across the Holocene. Philosophical Transactions of the Royal Society B, 366:2564-2576. https://doi.org/10.1098/rstb.2011.0020

Varona, L.S. 1970. Nueva especie y nuevo subgénero de Capromys (Rodentia: Caviomorpha) de Cuba. Poeyana, 74:1-16.

Vaughan, T.A. and Bateman, G.C. 1970. Functional morphology of the forelimb of mormoopid bats. Journal of Mammalogy, 51:217-235. https://doi.org/10.2307/1378472

Vieillot, L.J.P. 1808. Histoire naturelle des oiseaux de l'Amerique septentrionale. Chez Desray, Paris. 
Vigors, N.A. 1825a. Observations on the natural affinities that connect the orders and families of birds. Transactions of the Linnean Society of London, 14 (4):395-517. https://doi.org/10.1111/j.1095-8339.1823.tb00098.x

Vigors, N.A. 1825b. On the arrangement of the genera of birds. Zoological Journal, 2:391-405.

Vigors, N.A. 1827. On some species of birds from Cuba. Zoological Journal, 3:432-448.

Vento Canosa, E. 1990. Nuestra sociedad y la defensa de la patria (capitulo 32), p. 299-304. In Nuñez Jiménez, A. (ed.), Medio Siglo Explorando a Cuba (Tomo I). Imprenta Central de las FAR, La Habana.

Viera, R.A. 2004. Aportes a la quiropterofauna nacional. Revista de Espeleología y Arqueología, 5:21-23.

Viñola, L.W., Garrido, O.H., and Bermúdez A. 2018. Note on Mesocapromys sanfelipensis (Rodentia: Capromyidae) from Cuba. Zootaxa, 4410:164-176. https://doi.org/10.11646/zootaxa.4410.1.9

Waddell, P.J., Okada, N., and Hasegawa, M. 1999. Towards resolving the interordinal relationships of placental mammals. Systematic Biology, 48(1):1-5.

Wagler, J.G. 1832. Monographia Psittacorum. Abhandlungen der königl. Bayerischen Akademie der Wissenschaften, München, 1:463-750. https://doi.org/10.5962/bhl.title.51953

Woloszyn, B.W. and Silva Taboada, G. 1977. Nueva especie fósil de Artibeus (Mammalia: Chiroptera) de Cuba, y tipificación preliminar de los depósitos fosilíferos cubanos contentivos de mamíferos terrestres. Poeyana, 161:1-17. 